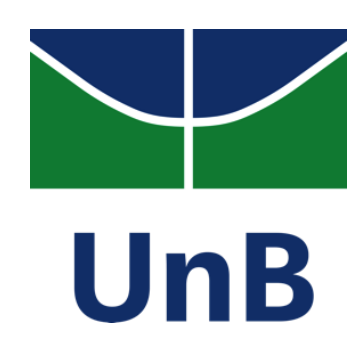

\title{
REDES SOCIAIS COMO FERRAMENTA DE ENSINO DOS FENÔMENOS ÓPTICOS
}

\author{
Samara Leite Brito Meira
}

Dissertação de Mestrado apresentada ao Programa de Pós-Graduação da Universidade de Brasília no Curso de Mestrado Profissional de Ensino de Física (MNPEF), como parte dos requisitos necessários à obtenção do título de Mestre em Ensino de Física.

Orientador:

Dr. Ronni Geraldo Gomes de Amorim, PhD

Brasília

Agosto 2016 


\title{
REDES SOCIAIS COMO FERRAMENTA DE ENSINO DOS FENÔMENOS ÓPTICOS
}

\author{
Samara Leite Brito Meira \\ Orientador: \\ Dr. Ronni Geraldo Gomes de Amorim, PhD
}

Dissertação de Mestrado submetida ao Programa de Pós-Graduação da Universidade de Brasília no Curso de Mestrado Profissional de Ensino de Física [MNPEF], como parte dos requisitos necessários à obtenção do título de Mestre em Ensino de Física

Aprovada por:

Dr. Ronni Geraldo Gomes de Amorim

Dr. Wytler Cordeiro dos Santos

Dr. Sebastião Ivaldo Carneiro Portela

Brasília

Agosto 2016 


\section{FICHA CATALOGRÁFICA}

S586p Meira, Samara Leite Brito

Redes sociais como ferramenta de ensino dos fenômenos ópticos / Samara Leite Brito Meira - Brasília: UnB/IF, 2016.

viii, 77 f.: il.; $30 \mathrm{~cm}$.

Orientador: Professor Dr. Ronni Geraldo Gomes de Amorim, PhD

Dissertação [mestrado] - UnB / Instituto de Física / Programa de Pós-Graduação em Ensino de Física, 2016.

Referências Bibliográficas: f. 74-77.

1. Ensino de Física. 2. Óptica. 3. Luz. 4. Edtech 5. Tecnologias Educacionais. 6. Métodos Ativos de Ensino. 7. TPACK 8. SMAR Model. Universidade de Brasília, Instituto de Física, Programa de Pós-Graduação em Ensino de Física. III. O uso das redes sociais como ferramenta de ensino dos fenômenos ópticos. 
Aos filhos, Matheus, Arthur e Maria Clara por serem meu porto seguro e minha fonte de vida. Cada linha desta dissertação é uma tentativa de desenhar uma escola diferente para vocês e para os meus futuros netos. 


\section{Agradecimentos}

Fazer agradecimentos em uma dissertação de mestrado é uma tarefa emocionante, ela marca o fim de uma etapa e nos faz lembrar do número de pessoas que se envolveram neste projeto junto com a gente, mostrando que um mestrado não pertence à seu autor, ele é, na verdade o resultado do trabalho em conjunto de vários agentes de transformação.

Eu começo pela minha família, meus filhos, Matheus, Arthur e Maria Clara sem vocês a minha vida não teria a menor graça, todos os dias e noites dedicados a este trabalho foram inspirados nas inúmeras vezes em que ainda pequenos vocês me questionaram à respeito do mundo, da lua, das estrelas! Obrigada por me desafiar, todos os dias, a ser mãe.

Ao meu amado marido, Max, por ser ombro amigo nas horas difíceis, por sua dedicação à nossa família, por se presença na minha ausência, por me apoiar sempre nos meus projetos malucos, obrigada por me amar até quando eu não mereço.

À minha amada mãe, Valda, por seu apoio incondicional em todos os momentos da minha vida, por ter olhado no fundo dos meus olhos há 19 anos e me pedido para nunca deixar de estudar. Sem você esta dissertação não estaria pronta. Obrigada por acreditar em mim, quando o mundo inteiro dizia que eu era incapaz.

À minha querida irmã Graziela, por sua força vital, por ser um exemplo de mãe e mulher que eu gostaria de ser para meus filhos e marido. Obrigada por me mostrar que às vezes é melhor recuar para depois seguir em frente, e como é importante olhar mundo sob outros pontos de vista.

Ao meu querido amigo e orientador Professor Dr. Ronni Amorim, por insistir que eu voltasse à academia. Para você, que fora meu colega de classe e hoje é o meu orientador, a minha eterna admiração e gratidão. 
Aos demais professores do curso, obrigada por compartilharem seus conhecimentos e por continuarem acreditando na educação.

Aos meus colegas do G4, Cézar, Fábio e Cícero, por serem ombro amigo, colegas de classe e muitas vezes meus professores durante esta caminhada. Obrigada por aceitarem uma menina no grupo de trabalho de vocês.

Ao amigo e parceiro de profissão, professor Jair Lúcio, agradeço às inúmeras sugestões no uso de novas estratégias na sala de aula, por me ajudar a enxergar um ensino para além dos conteúdos, por ter compartilhado as ideias deste projeto comigo e por ser um exemplo de professor-pesquisador.

Às minhas amigas, Ana Carolina Carvalho, Carla Arena, Clarissa Bezerra, Julianna Cauchick e Daniela Trovão, registro a minha gratidão. Obrigada por sonharem comigo e por deixar mais leve as minhas angustias, próprias das mulheres do novo século que se desdobram no papel de mãe, profissional, esposa, dona de casa e que além disso tudo escolheram a pesquisa como mais uma paixão. Este artigo também é uma homenagem à vocês que acreditam e lutam por uma educação libertadora que possa empoderar e transformar os nossos filhos em cidadãos do mundo.

À CAPES e ao GDF agradeço pelo apoio financeiro por meio da bolsa concedida durante todo o período acadêmico.

E por fim, meu agradecimento à Deus por, em sua infinita misericórdia, ter me dado a oportunidade de seguir em frente, por me manter em pé diante de todos os desafios que eu encontrei, por estender a sua mão para que eu não perdesse o caminho na busca dos meus sonhos de menina. 


\title{
RESUMO
}

\section{REDES SOCIAIS COMO FERRAMENTA DE ENSINO DOS FENÔMENOS ÓPTICOS}

\author{
Samara Leite Brito Meira \\ Orientador: \\ Dr. Ronni Geraldo Gomes de Amorim, PhD
}

Dissertação de Mestrado submetida ao Programa de Pós-Graduação da Universidade de Brasília no Curso de Mestrado Profissional de Ensino de Física [MNPEF], como parte dos requisitos necessários à obtenção do título de Mestre em Ensino de Física

Esta dissertação apresenta uma proposta didática para o ensino dos fenômenos ópticos por meio de uma rede social (Instagram). A proposta foi desenhada tendo como base a teoria do conectivismo [Siemens 2004] associada aos temas geradores de Paulo Freire, utilizando metodologias ativas de ensino e a teoria TPACK [Koehler 2006], em consonância ao modelo SMAR [Puentedura 2003] de adoção de tecnologias na sala de aula. O produto educacional é um site que servirá de modelo para educadores que desejem adotar novas estratégias didáticas permeadas pelo uso da tecnologia. $O$ estudo mostra o impacto positivo do uso das ferramentas tecnológicas associadas aos métodos centrados no estudante por meio de uma análise qualitativa e quantitativa dos resultados.

Palavras-chave: Ensino de Física. TPACK. SMAR. Conectivismo.

Brasília

Agosto 2016 


\section{ABSTRACT \\ SOCIAL MEDIA AS A TEACHING TOOL OF OPTICAL PHENOMENA}

Samara Leite Brito Meira

Supervisor:

Dr. Ronni Geraldo Gomes de Amorim, PhD

Abstract of master's thesis submitted to Pos Graduation program of University of Brasilia in Professional Master Course of Physicsl Education [MNPEF], in partial fulfillment of the requirements for the Master degree in Physics teaching.

This work presents a didactic proposal for teaching optical phenomena through a social network [Instagram]. The proposal was designed having based the theory of connectivism [Siemens 2004] associated with generating themes of Paulo Freire, using active teaching methodologies and TPACK theory [Koehler 2006] in line to SMAR model [Puentedura 2003] adoption of technologies in classroom. The educational product is a website that will serve as a model for educators who wish to adopt new teaching strategies permeated by use of technology. The study shows the positive impact of the use of technological tools associated with methods focused on the student through a qualitative and quantitative analysis of the results.

Keywords: Physics education. TPACK. SMAR. Conectivism.

Brasilia

August 2016 


\section{SUMÁRIO}

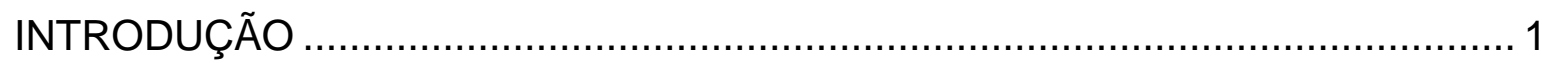

1. TECNOLOGIA, EDUCAÇÃO \& A GERAÇÃO Z .......................................... 9

1.1 Tecnologia e sua relação com a interatividade ........................................... 9

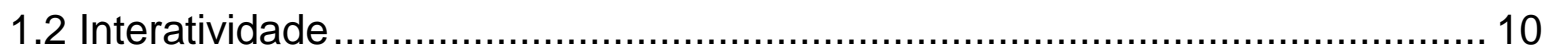

1.3 Histórico do uso de novas tecnologias no processo educacional.................... 11

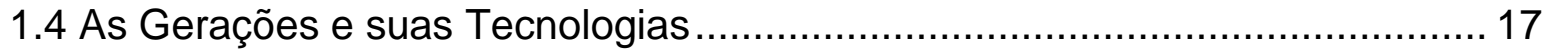

2. O USO DE TECNOLOGIA NA SALA DE AULA: UMA VISÃO

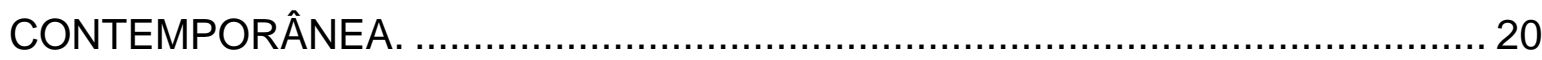

2.1 As tecnologias na sala de aula \& Processos de ensino e aprendizagem ........ 20 2.2 TPACK - Conhecimento Tecnológico, Pedagógico e de Conteúdo.................. 26

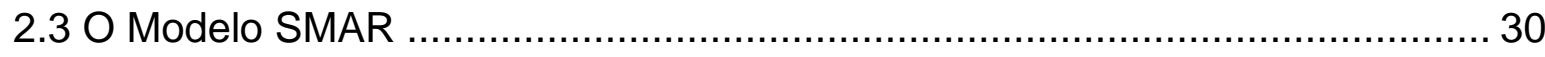

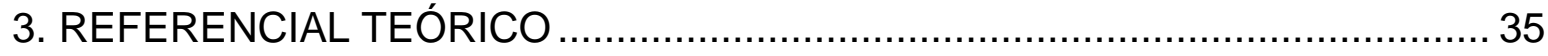

3.1 Os fenômenos ópticos no PCN e no ENEM ................................................ 45

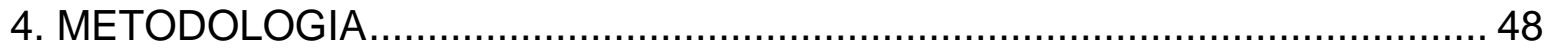

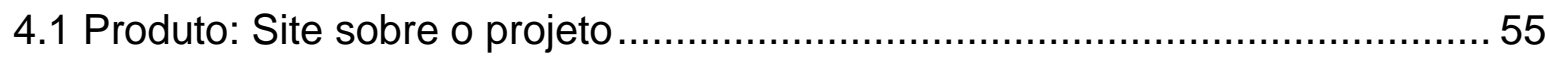

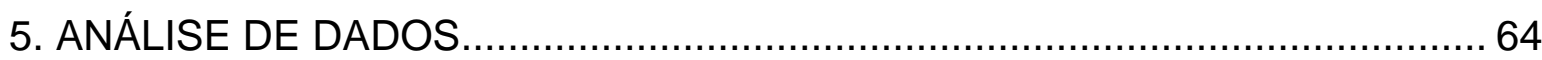

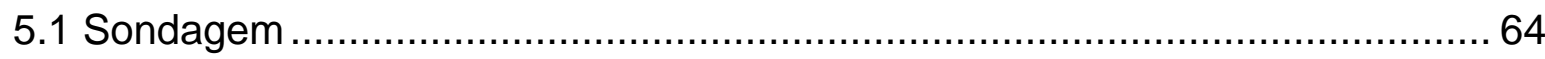

5.2 Aula de apresentação do Álbum Digital......................................................... 80

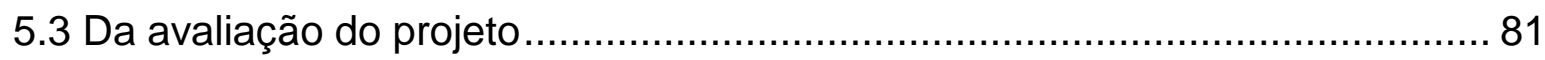

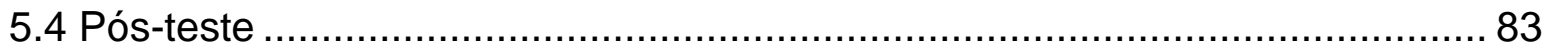

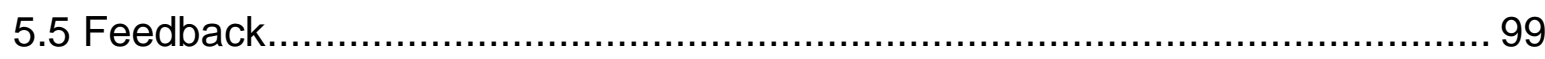

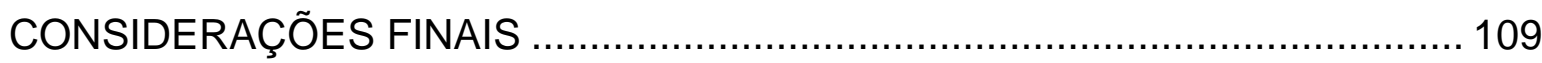

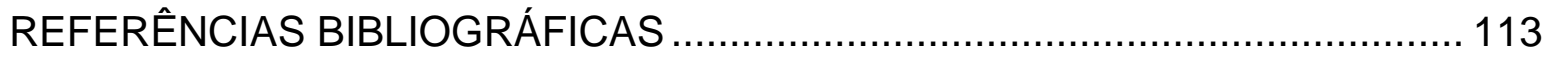




\section{ÍNDICE DE QUADROS}

QUADRO 1 - OBJETIVOS ESPECÍFICOS. FONTE: AUTORA. ........................................... 8

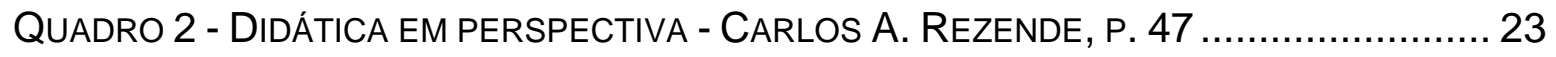

Quadro 3 - DidÁticA em PERSPECTIVA - CARLOS A. ReZENDE, P. 47 ......................... 24

QUADRO 4 - PRINCÍPIOS DO CONECTIVISMO ADAPTADO PELA AUTORA. ......................... 24

QUADRO 5 - NOVAS HABILIDADES A SEREM DESENVOLVIDAS PELOS PROFESSORES NO USO

DE NOVAS TECNOLOGIAS NA SALA DE AULA. ............................................... 28

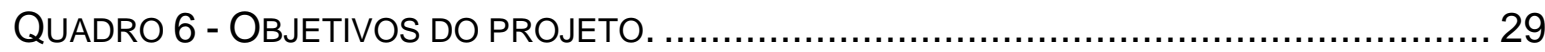

QUADRO 7 - EleMENTOS DA AÇÃo diaLÓGICA. PAULO FrEIRE................................... 43

QUADRO 8 - COMPETÊNCIAS E HABILIDADES APRESENTADAS NO PCN CONTEMPLADOS

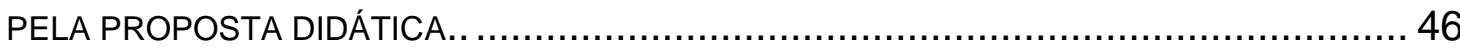

QUADRO 9 - COMPETÊNCIAS E HABILIDADES DO ENEM CONTEMPLADOS PELA PROPOSTA

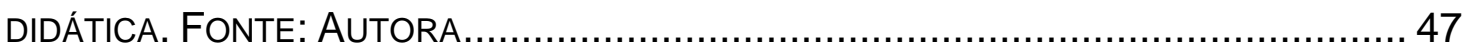

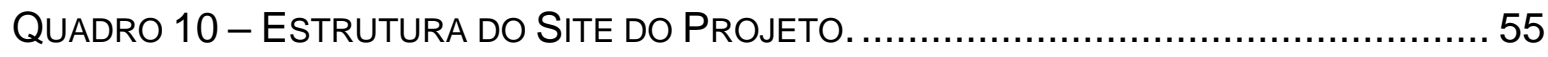

QUADRO 11 - MÉDIA DAS NOTAS ALCANÇADAS NA ATIVIDADE DE SONDAGEM................ 79

QuAdro 12 - RubRICA dE AVALIAÇÃo. Créditos: AutORA ...................................... 82

QUADRO 13 - CAPTURA DE TELA DA TABELA GERADA PARA AVALIAÇÃO DO PROJETO..... 82

QUADRO 14 - PLANILHA UTILIZADA PARA DAR NOTAS AOS ESTUDANTES NO PROJETO. ... 83

QUADRO 15 - MÉDIA DOS ESTUDANTES NA ATIVIDADE DE PÓS-TESTE ......................... 98

QUADRO 16 - COMENTÁRIOS POSITIVOS E NEGATIVOS A RESPEITO DO PROJETO. ......... 108 


\section{ÍNDICE DE FIGURAS}

FIGURA 1 - QUANTO TEMPO VOCÊ PASSA AS REDES SOCIAIS? ................................ 14

FIGURA 2 - ESTILO DE VIDA DAS GERAÇÕES - NIELSON GLOBAL ................................. 17

FIGURA 3 - DIFERENÇAS ENTRE AS GERAÇÕES. ................................................. 19

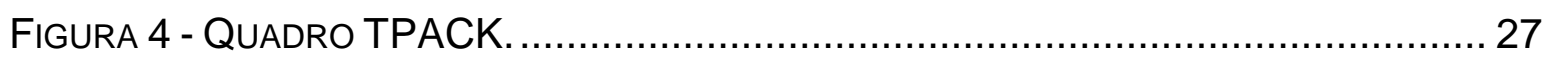

FIGURA 5 - FIGURA X: QUADRO TPACK PARA O PROJETO FENÔMENOS ÓPTICOS .......... 30

FIGURA 6 - MODELO SMAR DE UTILIZAÇÃO DA TECNOLOGIA …................................. 31

FIGURA 7 - MODELO SMAR DE UTILIZAÇÃO DA TECNOLOGIA SOB O PONTO DE VISTA DA

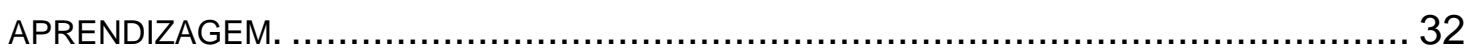

FIGURA 8 - MODELO SMAR DE UTILIZAÇÃO DA TECNOLOGIA SOB O PONTO DO TRABALHO

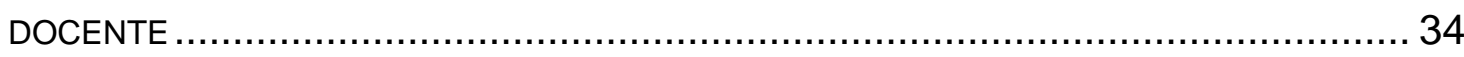

Figura 9 - Diagrama da CONCEPÇÃo FreIREANA APLICADA AO ENSINO dE FísICA. ..... 37

FIGURA 10 - DIAGRAMA DE COMPARAÇÃO DAS METODOLOGIAS TRADICIONAIS E ATIVAS. 39

FIGURA 11 - DIAGRAMA DE COMPARAÇÃO DAS METODOLOGIAS TRADICIONAIS E ATIVAS QUANDO UTILIZADAS COM BASE NA TEORIA DO CONECTIVISMO............................. 40

FIGURA 12 - CAPTURA DE TELA DE FOTO DISPONÍVEL NO INSTAGRAM. ........................ 41

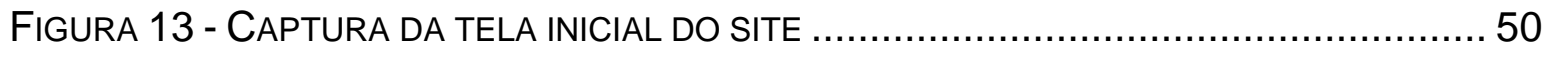

FIGURA 14 -CAPTURA DA TELA DO FORMULÁRIO APLICADO EM SALA..........................51

FIGURA 15 - CAPTURA DE TELA DO INSTAGRAM EM PESQUISA SOB A HASHTAG:

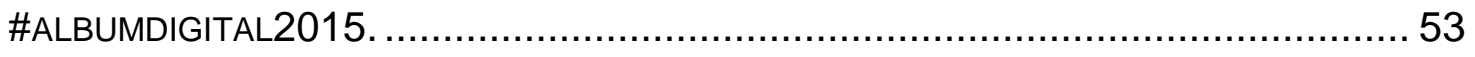

FIGURA 16 - CAPTURA DE TELA DO INSTAGRAM DE UMA DAS FOTOS APRESENTADAS

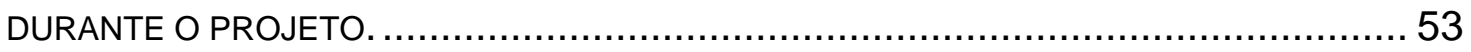

Figura 17 - Aplicação do Pós-teste. Fonte: CAPTURA de TELA do Site do PROJeto 54

FIGURA 18 - CAPTURA DA TELA DA PÁGINA INICIAL DO SITE. .......................................56

FIGURA 19 - CAPTURA DA TELA DOS OBJETIVOS DO PROJETO................................... 56

FIGURA 20 - CAPTURA DA TELA DA MOTIVAÇÃO PARA O PROJETO................................ 57

FIGURA 21 - CAPTURA DA TELA DE APRESENTAÇÃO DO PROJETO. ...............................5 57 
FIGURA 22 - CAPTURA DA TELA QUE APRESENTA OS TEMAS DO PROJETO. 58

FIGURA 23 - CAPTURA DA TELA COM OS DESAFIOS QUE OS ESTUDANTES TERÃO QUE REALIZAR PARA CONSTRUIR O SEU PROJETO. .................................................. 58

FIGURA 24 - CAPTURA DA TELA DO CRONOGRAMA DO PROJETO. ..................................59

FIGURA 25 - CAPTURA DA TELA DOS CRITÉRIOS DE AVALIAÇÃO...................................6 60

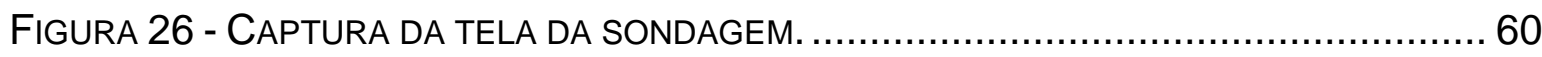

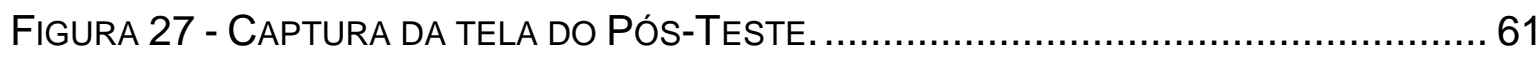

FIGURA 28 - CAPTURA DA TELA DO FORMULÁRIO DE FEEDBACK.................................. 61

FIGURA 29 - CAPTURA DA TELA DA EQUIPE ORGANIZADORA DO PROJETO.......................62

FIGURA 30 - CAPTURA DA TELA DA MENSAGEM PARA OS PROFESSORES. .....................62

FIGURA 31 - CAPTURA DA TELA DA DO FORMULÁRIO UTILIZADO PARA AVALIAR AS FOTOS

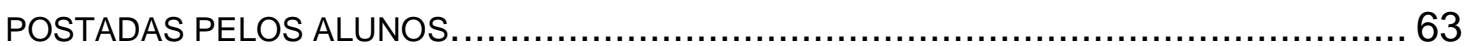

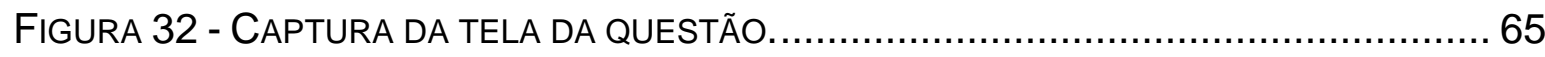

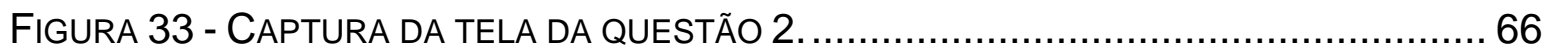

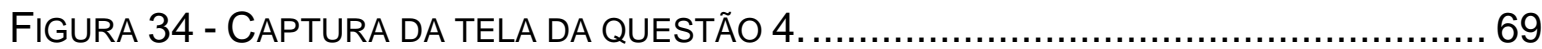

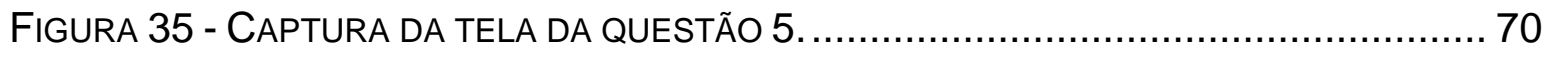

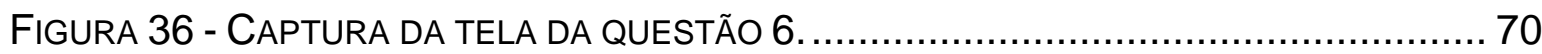

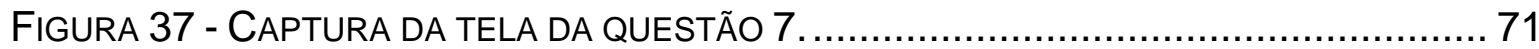

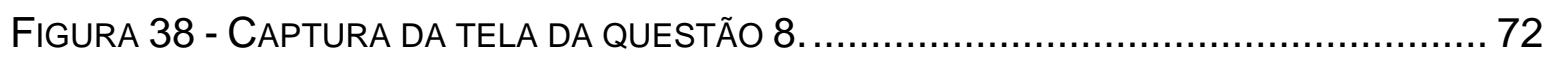

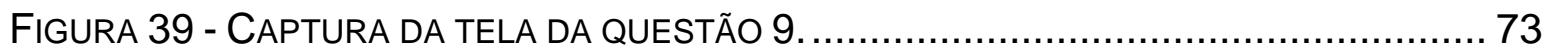

FIGURA 40 - CAPTURA DA TELA DA QUESTÃO 10 ................................................. 74

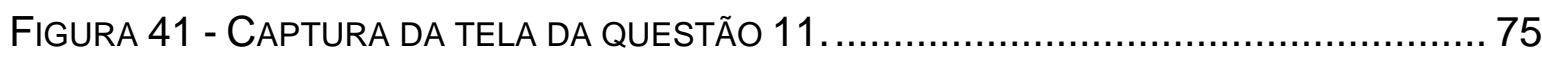

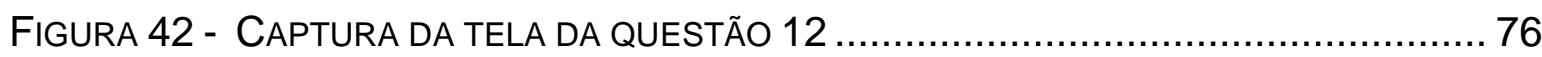

FIGURA 43 - CAPTURA DA TELA DA QUESTÃO 13 .................................................. 77

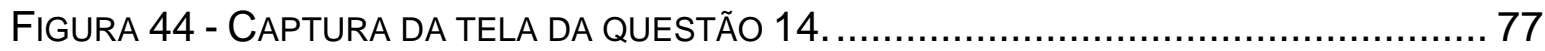

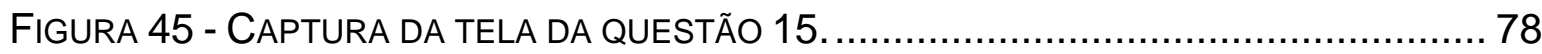

FIGURA 46 - CAPTURA DA TELA DA ESCALA UTILIZADA PARA AVALIAÇÃO DO PROJETO..... 82

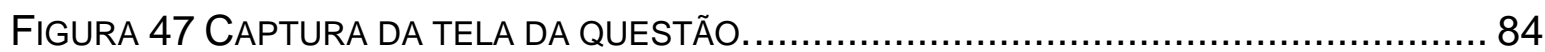

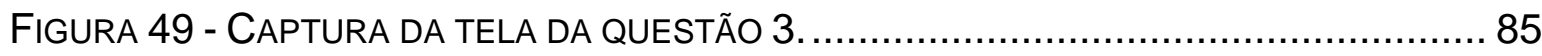

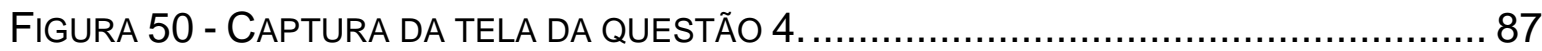




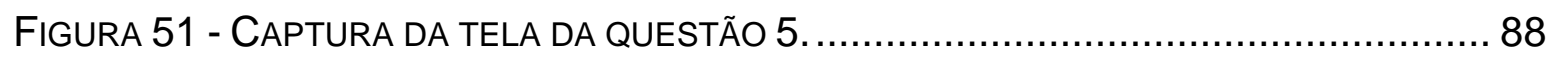

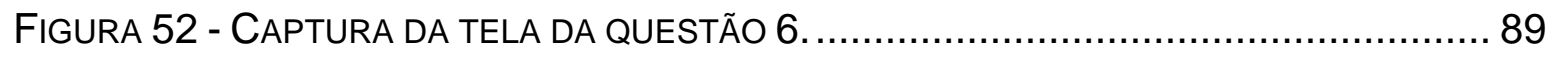

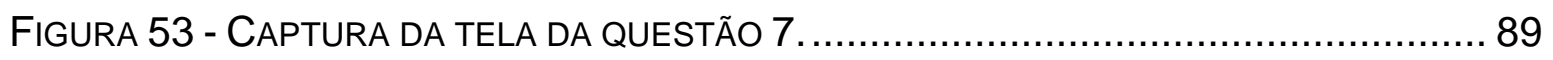

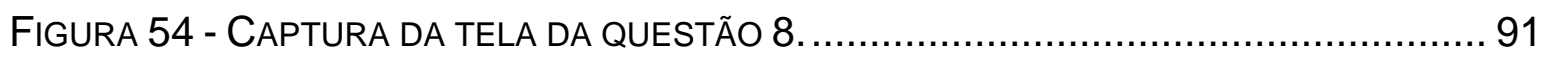

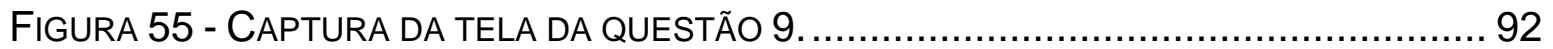

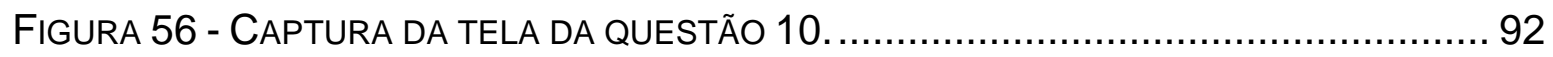

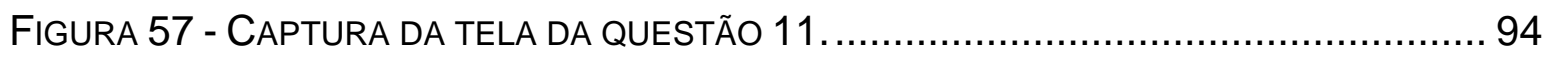

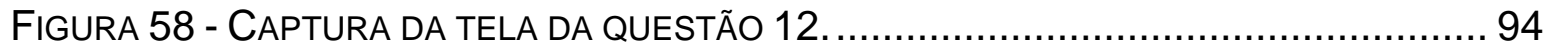

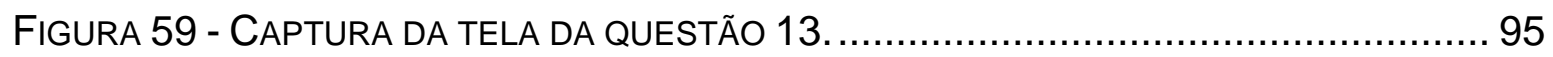

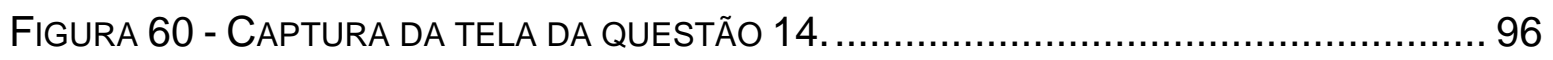

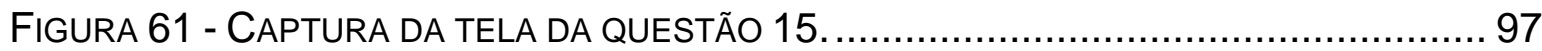

FIGURA 62 - CAPTURA DE TELA DO FORMULÁRIO APLICADO................................... 101

FIGURA 63 - CAPTURA DE TELA DA PRIMEIRA PERGUNTA DO FEEDBACK ..................... 101

FIGURA 64 - CAPTURA DE TELA DA SEGUNDA PERGUNTA DO FEEDBACK …................. 102

FIGURA 65 - CAPTURA DE TELA DA TERCEIRA PERGUNTA DO FEEDBACK......................103

FIGURA 66 - CAPTURA DE TELA DA QUARTA PERGUNTA DO FEEDBACK...................... 104

FIGURA 67 - CAPTURA DE TELA DA QUINTA PERGUNTA DO FEEDBACK...................... 105

FIGURA 68 - CAPTURA DE TELA DA SEXTA PERGUNTA DO FEEDBACK..........................105

FIGURA 69 - CAPTURA DE TELA DA SEXTA PERGUNTA DO FEEDBACK......................... 106

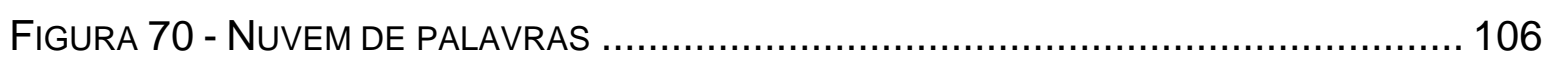




\section{ÍNDICE DE GRÁFICOS}

GRÁFICO 1 - PROPORÇÃo dE ALUNOS QUE ACESSARAM A INTERNET POR MEIO DO

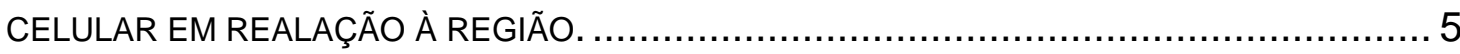

GRÁFICO 2 - PROPORÇÃO dE ALUNOS QUE ACESSARAM A INTERNET POR MEIO DO

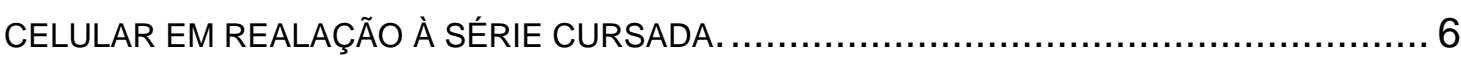

GRÁFICO 3 - PORCENTAGEM DOS ACESSOS ÀS REDES SOCIAIS NO BRASIL..................... 7

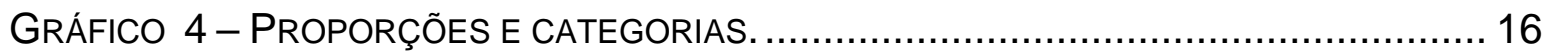

GRÁFICO 5 - DISTRIBUIÇÃO DAS RESPOSTAS DA QUESTÃO 1..................................6

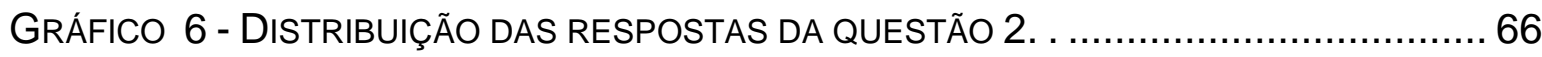

GRÁFICO 7 - DISTRIBUIÇÃO DAS RESPOSTAS DA QUESTÃO 3.................................... 67

GRÁFICO 8 - DISTRIBUIÇÃO DAS RESPOSTAS DA QUESTÃO 4.......................................69

GRÁFICO 9 - DISTRIBUIÇÃO DAS RESPOSTAS DA QUESTÃO 5 .................................. 70

GRÁFICO 10 - DISTRIBUIÇÃO DAS RESPOSTAS DA QUESTÃO 6 .................................. 71

GRÁFICO 11 - DISTRIBUIÇÃO DAS RESPOSTAS DA QUESTÃO 7................................ 71

GRÁFICO 12 - DISTRIBUIÇÃO DAS RESPOSTAS DA QUESTÃO 8 ................................. 73

GRÁFICO 13 - DISTRIBUIÇÃO DAS RESPOSTAS DA QUESTÃO 9.................................. 73

GRÁFICO 14 - DISTRIBUIÇÃO DAS RESPOSTAS DA QUESTÃO 10 …........................... 74

GRÁFICO 15 - DISTRIBUIÇÃO DAS RESPOSTAS DA QUESTÃO 11 ................................ 75

GRÁFICO 16 - DISTRIBUIÇÃO DAS RESPOSTAS DA QUESTÃO 12 ................................. 76

GRÁFICO 17 - DISTRIBUIÇÃO DAS RESPOSTAS DA QUESTÃO 13 ……....................... 77

GRÁFICO 18 - DISTRIBUIÇÃO DAS RESPOSTAS DA QUESTÃO 14 ............................. 78

GRÁFICO 19 - DISTRIBUIÇÃO DAS RESPOSTAS DA QUESTÃO 15...............................78

GRÁFICO 20 - DISTRIBUIÇÃO DAS RESPOSTAS DA QUESTÃO 1 - PÓS-TESTE................... 84

GRÁFICO 21 - DISTRIBUIÇÃO DAS RESPOSTAS DA QUESTÃO 2 - PÓS-TESTE.................. 85

GRÁFICO 22 - DISTRIBUIÇÃO DAS RESPOSTAS DA QUESTÃo 3 - PÓS-TESTE................... 86

GRÁFICO 23 - DISTRIBUIÇÃO DAS RESPOSTAS DA QUESTÃO 4 - PÓS-TESTE................... 87

GRÁFICO 24 - DISTRIBUIÇÃO DAS RESPOSTAS DA QUESTÃO 5 - PÓS-TESTE................... 88

GRÁFICO 25 - DISTRIBUIÇÃO DAS RESPOSTAS DA QUESTÃo 6 - PÓS-TESTE................... 89 
GRÁFICO 26 - DISTRIBUIÇÃO DAS RESPOSTAS DA QUESTÃO 7 - PÓS-TESTE.................... 90

GRÁFICO 27 - DISTRIBUIÇÃO DAS RESPOSTAS DA QUESTÃO 8 - PÓS-TESTE.................... 91

GRÁFICO 28 - DISTRIBUIÇÃO dAS RESPOSTAS DA QUESTÃO 9 - PÓS-TESTE.................... 92

GRÁFICO 29 - DISTRIBUIÇÃO dAS RESPOSTAS DA QUESTÃo 10 - PÓS-TESTE.................. 93

GRÁFICO 30 - DISTRIBUIÇÃO dAS RESPOSTAS DA QUESTÃO 11 - PÓS-TESTE..................99

GRÁFICO 31 - DISTRIBUIÇÃO dAS RESPOSTAS DA QUESTÃO 12 - PÓS-TESTE.................. 95

GRÁFICO 32 - DISTRIBUIÇÃO dAS RESPOSTAS DA QUESTÃO 13 - PÓS-TESTE..................96

GRÁFICO 33 - DISTRIBUIÇÃO dAS RESPOSTAS DA QUESTÃo 14 - PÓS-TESTE.................. 96

GRÁFICO 34 - DISTRIBUIÇÃO DAS RESPOSTAS DA QUESTÃO 15 - PÓS-TESTE.................. 97

GRÁFICO 35 - COMPARAÇÃo dOS RESULTADOS DA SONDAGEM E DO PÓS-TESTE...........99

GRÁFICO 36 - DISTRIBUIÇÃO dA ESCALAS DA PRIMEIRA PERGUNTA dO FEEDBACK ....... 102

GRÁFICO 37 - DistribUIÇÃo dA ESCALAS dA SEGUNDA PERGUNTA DO FEEDBACK ....... 102

GRÁFICO 38 - DistRIBUIÇÃo dA ESCALAS DA TERCEIRA PERGUNTA Do FEEDBACK ..... 103

GRÁFICO 39 - DISTRIBUIÇÃO dA ESCALAS DA QUARTA PERGUNTA DO FEEDBACK ......... 104

GRÁFICO 40 - DISTRIBUIÇÃO DA ESCALAS DA QUINTA PERGUNTA DO FEEDBACK .......... 105

GRÁFICO 41 - DistRIBUIÇÃo dA ESCALAS dA SEXTA PERGUNTA do FEEDBACK ........... 105 


\section{INTRODUÇÃO}

Malala Yousafzai', 17 anos, em um discurso afirmou prontamente, "um livro, uma caneta, uma criança e um professor podem mudar o mundo." A jovem paquistanesa, prêmio Nobel da Paz, luta pelo acesso à educação, surpreendeu o mundo ao se declarar a favor da escola. Malala, como tantos outros que encontramos na sala de aula, acredita que uma boa educação é capaz de transformações profundas na sociedade. A história da menina apresenta-se como um desafio aos educadores do mundo inteiro, mostra a necessidade de uma educação que vai além do ensino formal, as palavras da menina soam com um chamado do novo século: é preciso despertar e empoderar as inúmeras Malalas que encontramos por aí.

Malala luta para que seus compatriotas tenham acesso à educação. Em situações como a da paquistanesa, os quatro elementos citados, livro, caneta, criança e professor, podem ajudar a dar o primeiro passo, mas, quando nos referimos a uma educação libertadora [Freire, 1968], para a vida e para as necessidades do novo século, acreditamos ser possível acrescentar mais um ingrediente. Malala teve suas palavras amplificadas por este pequeno dispositivo, bastante eficaz para dar voz as meninas como ela, e que tem potencial de mudar o atual cenário educacional e provocar uma verdadeira ressignificação do papel do educador.

O ingrediente a que nos referimos é o Smartphone, o tablet ou quaisquer outros dispositivos móveis. Esses dispositivos podem ser descritos como aparelhos incrivelmente ágeis. $\mathrm{O}$ design leve e fino permite que sejam levados

\footnotetext{
${ }^{1}$ Jovem ativista paquistanesa, considerada a pessoa mais nova a ser laureada com um prêmio Nobel da Paz. É conhecida principalmente pela defesa dos direitos humanos das mulheres e do acesso à educação na sua região natal do vale do Swat na província de Khyber Pakhtunkhwa, no nordeste do Paquistão, onde os talibãs locais impedem as jovens de frequentar a escola. Desde então, o ativismo de Malala tornou-se um movimento internacional. Ela possuía um blog: www.malala-yousafzai.com, que mais tarde foi transformado em livro - I Am Malala: The Girl Who Stood Up for Education and Was Shot by the Taliban - Paperback 2 de Junho, 2015 [Adaptado de https://pt.wikipedia.org/wiki/Malala Yousafzai acesso em Junho/2016]
} 
tranquilamente para qualquer lugar. $\mathrm{Na}$ realidade, não representam apenas um melhor instrumento tecnológico para a execução de tarefas, mas um recurso inovador com potencial de mudar o cenário do aprendizado. Vamos tomar a liberdade de usar as mesmas palavras dessa moça inspiradora e acrescentar: "Um livro, uma caneta, uma criança e um professor conectados por um dispositivo móvel podem mudar o mundo."

Considerando o potencial de interferência desses dispositivos no aprendizado, torna-se imperativo analisar, multidimensionalmente, o processo de entrada dessa tecnologia na sala de aula. Não é apenas agilidade e leveza, mas também a conectividade, '24horabilidade' multiplicada, a rotatividade de aplicativos e, sobretudo, um elemento muito mais presente no estilo de vida dos alunos do que dos professores [Giglio e Souza, 2013]. A partir dessa perspectiva, esses novos dispositivos têm potencial para personalizar o aprendizado atual, uma vez que o modelo educacional tradicional é amplamente reconhecido como modelo one-way de transferência de conhecimentos e que segundo Freeman et al, 2014, p. 8410 está se tornando ineficaz.

Os dados sugerem que os professores de Ciências, Tecnologia, Engenharia e Matemática (STEM) podem começar a questionar o uso continuado de aulas no formato tradicional de palestras na prática cotidiana, especialmente à luz dos recentes trabalhos, indicando que a aprendizagem ativa confere maiores benefícios para os estudantes STEM oriundos de meios desfavorecidos e para estudantes do sexo feminino em áreas dominadas pelos homens. Embora aulas tradicionais tenham dominado o ensino de graduação para mais de um milênio e continua a ter fortes defensores, a evidência atual sugere que uma abordagem construtivista "pergunte, não diga" pode levar a fortes aumentos no desempenho acadêmico dos estudantes. ${ }^{2}$

Quando professores e palestrantes começarem a criar novas formas de combater a obsolescência, os tablets/smartphones poderão desempenhar um

\footnotetext{
2 Tradução da autora.
} 
papel transformador, pois de educação tem muito a ver com futuro, porque, em parte, o futuro depende da educação [Demo, 2005].

A transformação será mais palpável quando todas as funcionalidades em potencial dos tablets/smartphones forem somadas às câmeras e aos aplicativos, assim tornando-se um estúdio de aprendizagem pessoal. Abre-se, então, um leque de opções, como um laboratório de Ciências, uma ferramenta de alfabetização, uma estação de pesquisa ou até um arquivo histórico, no qual se pode utilizar a linguagem do laboratório, da arte, do estúdio de música, da edição de vídeo, do console de jogos e ainda de uma biblioteca de textos e imagens, tal como vamos propor nesta dissertação.

Numa pesquisa realizada em 2012, Wang e Tchernev [2012, p.89] recrutaram 32 estudantes universitários que concordaram em reportar como utilizavam as mídias durante as suas atividades regulares. Os estudantes afirmaram que quando eles optavam por realizar uma tarefa concomitante a outra, por exemplo, assistir TV enquanto leem os textos da faculdade os manteve mais motivados a terminar a tarefa acadêmica. Além disso, as multitarefas ocorriam em maior quantidade quando eles precisaram estudar ou trabalhar. Os resultados da pesquisa mostram que os estudantes multitarefas se sentiam emocionalmente mais satisfeitos, quando comparados aos jovens que estudavam sem o uso de alguma mídia. A pesquisa vai ao encontro ao que observamos em nossas salas de aula, encontramos estudantes que estão altamente adaptados às multitarefas, resolvem exercícios escutando música ou pesquisam algo referente à aula no celular enquanto explicamos o conteúdo.

Contudo, esta nova habilidade é pouco explorada durante nossas aulas. $O$ uso da tecnologia e a velocidade são comuns a essa geração e há a necessidade em se explorar este caminho. Além disso, vivemos em uma era tecnológica em que constantemente surgem novas ferramentas - leia-se, também, aplicativos com inúmeras possibilidades de uso nos mais variados setores. Essas inovações não demorariam a chegar ao ambiente escolar. 
Nesta dissertação, entende-se que toda essa tecnologia pode fazer diferença no ensino e ser bem aplicada no dia a dia escolar, uma vez que invadiu as aulas, adentrando na rotina diária de muitas escolas por todo o mundo pelas mãos dos alunos, a despeito da vontade dos educadores. Pelos estudantes é percebida como algo natural e para os professores pode, portanto, servir como grande aliada à aprendizagem, se os alunos forem estimulados a utilizá-la em prol do desenvolvimento dos próprios intelectos.

Não devemos nos esquecer de que estamos falando de uma geração conhecida como geração $Z^{3}$, normalmente indivíduos nascidos ao final do século XX começo do XXI, entre 1990 e 2009. Essa geração, conforme vamos observar nesta dissertação, possui uma característica: ficar constantemente disponível e conectada por meio de dispositivos móveis. Precisa-se, portanto, entender como a tecnologia foi parar no ambiente escolar, que se comporta como um solo fértil para a germinação do que chamamos de tecnologia. Para Binsfeld e Auth quando:

Consideramos a ciência um processo de constante busca de conhecimento, de produções e socializações de seus resultados, para além do livro didático e das revistas, outras formas de publicação vêm sendo disseminadas, com importante papel de difundir/divulgar conhecimentos em âmbitos culturais diversificados, também importantes para o processo do conhecimento escolar. [Binsfeld e Auth, 2000, p. 02]

Toda essa linha de raciocínio serve de pretexto e interesse para que os pesquisadores tracem seus objetivos com os seus estudos. Portanto o objetivo geral desta pesquisa está relacionado à verificação da eficiência do uso de novas tecnologias e suas possibilidades pedagógicas, mais especificamente na aprendizagem de fenômenos ópticos por meio de uma rede social, neste caso, o Instagram.

Também devemos observar que, no Brasil, o uso de Internet por meio do celular vem aumentando a cada ano. De acordo com dados do comitê gestor da

\footnotetext{
${ }^{3}$ Conheça as gerações no Capítulo 1 - Secção 1.4
} 
internet no Brasil, em 2014, o percentual de alunos que utilizaram a rede por meio do celular, é bastante significativo e deve ser considerado pelos educadores como dentro de uma tendência mundial conforme ilustra o gráfico a seguir que apresenta a proporção, por região, de alunos que acessaram à internet por meio do celular.

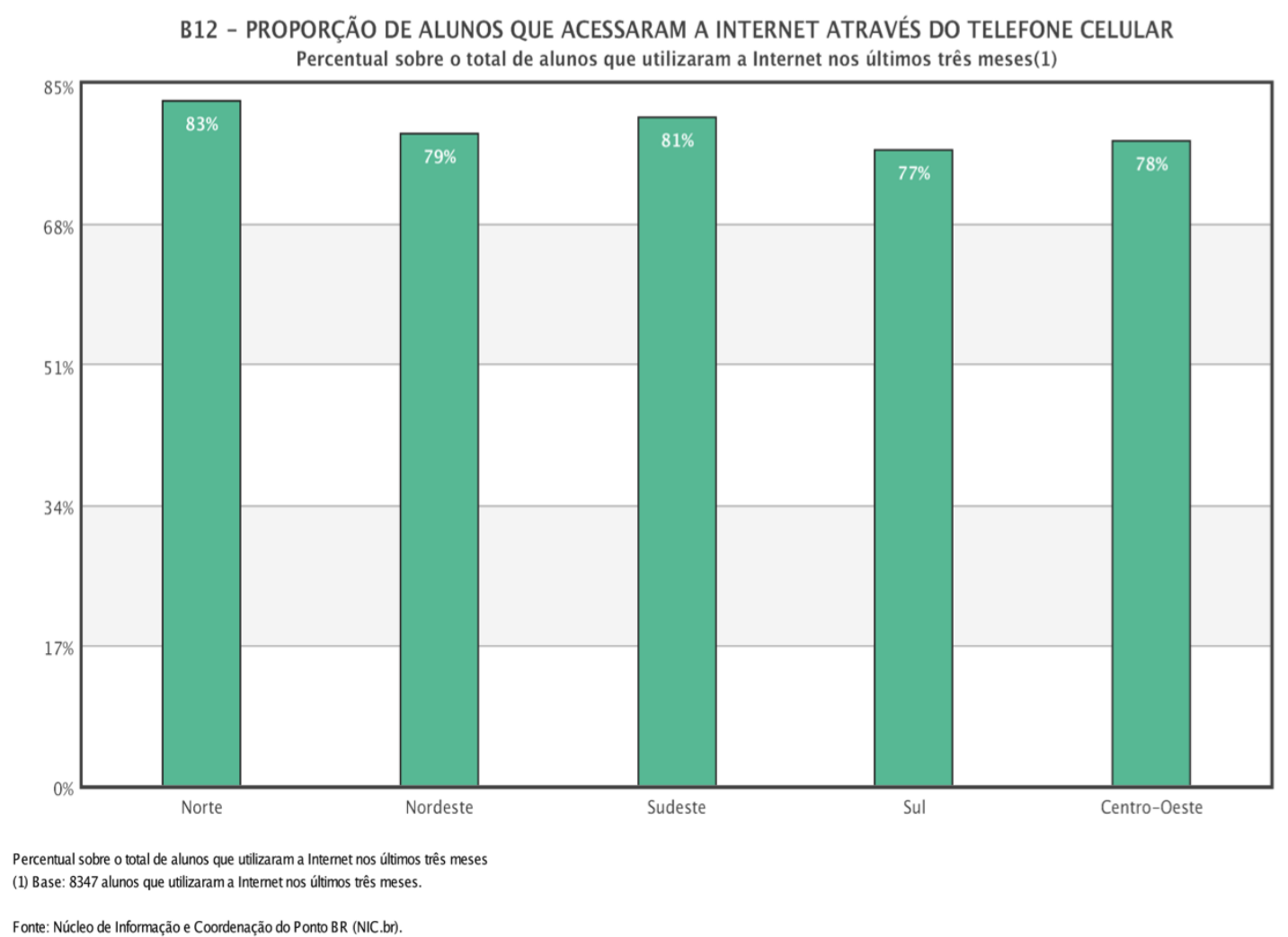

Gráfico 1 - Proporção de alunos que acessaram a internet por meio do celular em relação à região. Fonte: <http://data.cetic.br/>. Acesso em junho 2016

Além disso, segundo o mesmo estudo, cerca de $90 \%$ dos estudantes do ensino médio, utiliza o celular como forma de acesso à internet.

Diante do acesso crescente a um vasto campo de informações pelas pessoas em geral e os estudantes em particular, não é mais tolerável à escola o papel de transmitir pacotes repetitivos de informações e/ou veicular novidades, de forma fragmentada. Cabe repensar cada vez mais os processos de formação, na perspectiva de contribuírem sistematicamente para o exercício da cidadania. [Binsfeld e Auth, 2000, p. 03] 
B12 - PROPORÇÃO DE ALUNOS QUE ACESSARAM A INTERNET ATRAVÉS DO TELEFONE CELULAR

Percentual sobre o total de alunos que utilizaram a Internet nos últimos três meses(1)

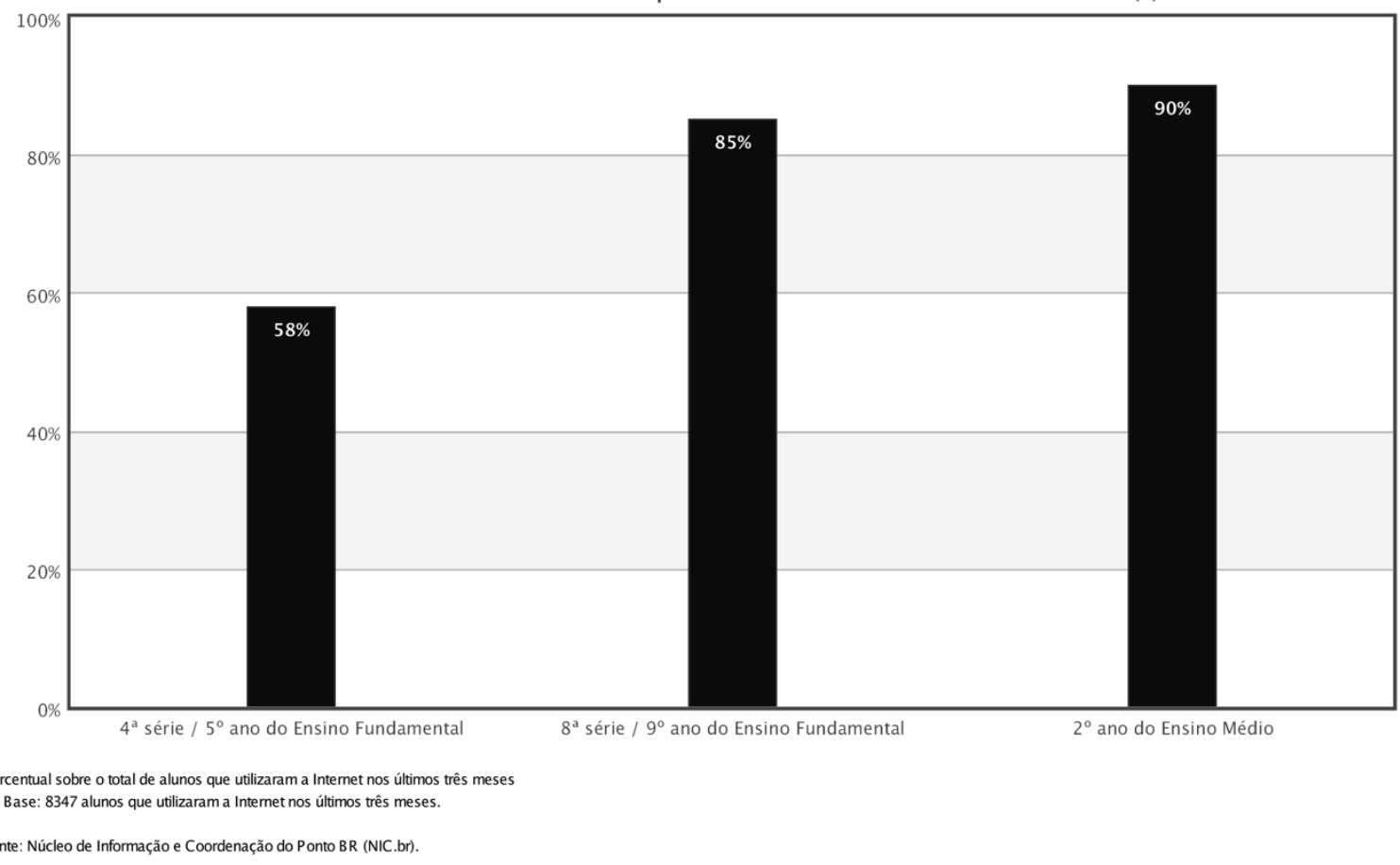

Gráfico 2 - Proporção de alunos que acessaram a internet por meio do celular em relação à série cursada. Fonte: <http://data.cetic.br/> Acesso em junho 2016

Ao analisarmos o uso das redes sociais em nosso país, podemos perceber como é difícil nos deparamos com alguém que não faça parte de uma rede social online como o Facebook e o Twitter, por exemplo. O gráfico a seguir mostrar o percentual de acesso as redes sociais no Brasil. A internet é um meio privilegiado de comunicação entre professores e estudantes, de modo que exige postura dinâmica de ambos no que concerne à aprendizagem [Moran, 2008]. Ao professor cabe o papel de orientar, estimular e acompanhar as atividades e pesquisas realizadas pelos alunos. Aos discentes, cabe a função ativa no manuseio de informação digital para a construção do conhecimento. O objetivo é educar os estudantes para a autonomia, permitindo-lhes que sejam protagonistas no desenvolvimento do saber, de acordo com seu ritmo. 


\section{Acesso às redes socias}

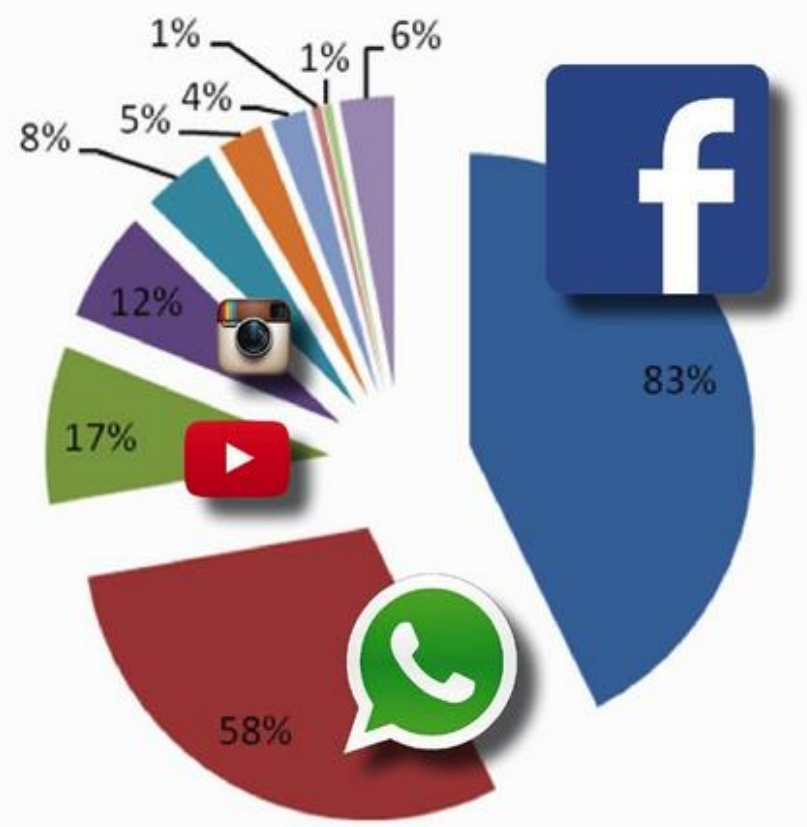

Facebook

Whatsapp

- Youtube

- Instagram

Google+

- Twitter

- Skype

Linkedin

Outros

não utiliza

Gráfico 3 - Porcentagem dos acessos às redes sociais no Brasil.

Fonte: Pesquisa Brasileira de Mídia, 2015 [PBM]

Portanto, nossa hipótese é de que, de acordo com a teoria do conectivismo [Siemens, 2010], uma rede social, neste caso o Instagram, seria um instrumento eficaz como facilitador na aprendizagem dos fenômenos ópticos além de contribuir com a divulgação científica e proporcionar aprendizagem em rede [Abegg e Bastos, 2012].

Dessa forma o objetivo geral desta pesquisa foi o desenvolvimento de um produto educacional que possibilita 0 uso das ferramentas tecnológicas na aprendizagem de fenômenos ópticos. O produto a que nos referimos é uma sequência didática elaborada considerando os temas geradores de Paulo Freire e a teoria do conectivismo de Siemens e está disponível em formato digital no site: bit.ly/fenomenosopticos.

Nesta proposta didática foram trabalhados os seguintes objetivos específicos: 
Relatar o processo de entrada dos dispositivos móveis em sala de aula.

llustrar como uma rede social, neste caso o Instagram, pode influenciar o aprendizado e contribuir para divulgação científica.

Aplicar uma atividade utilizando uma rede social, neste caso o Instagram, com o uso dos dispositivos móveis utilizando-o como ferramenta aprendizagem e divulgação científica.

Debater com os estudantes os conceitos físicos abordados durante a atividade.

Analisar a evolução do conhecimento adquirido durante a realização da proposta didática por meio de pré-teste e pós-teste.

Investigar a percepção dos estudantes sobre as vantagens e desvantagens do uso dessas novas tecnologias no processo de aprendizagem.

Quadro 1 - Objetivos Específicos. Fonte: Autora.

Nos capítulos a seguir serão apresentados os estudos realizados e a metodologia adotada para a construção da sequência didática utilizada no site do projeto. 


\section{TECNOLOGIA, EDUCAÇÃO \& A GERAÇÃO Z}

\subsection{Tecnologia e sua relação com a interatividade}

No ímpeto de avaliar o uso de dispositivos eletrônicos na sala de aula, surgiu a necessidade de pesquisar minuciosamente a esfera semântica do termo tecnologia, bem como relacioná-lo à ideia de interatividade, uma vez que a dinamicidade do processo de ensino-aprendizagem leva à abordagem desse tema.

Etimologicamente, o termo "tecnologia" vem do grego techné. Associado a este conceito do termo techné, está o termo logia, que é derivado do grego logus, que significa razão; estudo. Com base nessa noção, infere-se que tecnologia é, resumidamente, o estudo da técnica ou do instrumento. Assim, tecnologia aplicada refere-se ao estudo das ferramentas utilizadas pelo ser humano em diversos domínios do conhecimento, como telescópios na ciência astronômica [Veraszto et al., 2009].

Aqui entra, então, a relação que há entre a tecnologia e a interatividade, uma vez que, etimologicamente, o prefixo "inter" também significa entre; portanto a interatividade seria a relação entre o instrumento e o homem. A conclusão a que se chega é que a interatividade seria o objeto de estudo e desenvolvimento da tecnologia.

Desse modo, o desenvolvimento dessa conceituação permite avaliar de maneira dimensional uma gama de situações, tal como a utilização de tablets no processo de ensino e aprendizagem e, analisando mais profundamente esse tópico, temos o tablet como o instrumento utilizado para estimular a relação entre a tecnologia e a interatividade existente no ambiente escolar. 


\subsection{Interatividade}

A interatividade tem se tornado uma expressão com um conceito muito amplo. Ela, em alguma medida, visa se aproximar e atualizar de algum outro termo mais antigo do campo semântico de "interação", visto que interagir é submeter-se a uma troca de informações e conhecimentos. Sendo assim, esse conceito se aproxima bastante do que o termo "interatividade" propõe.

Sobre a cibercultura [Lemos, 2005], por exemplo, advoga que a interatividade é um caso específico de interação, a "interatividade digital", compreendida como um tipo de relação tecnossocial, ou seja, como um diálogo entre homem permeados pela máquina, por meio de interfaces gráficas, em tempo real. Entretanto, as interações entre a internet e a sociedade, a interatividade [Lévy, 1997], assinala muito mais um problema, a necessidade de um novo trabalho de observação, de concepção e de avaliação dos modos de comunicação do que uma característica simples e unívoca atribuível a um sistema específico, não se limitando, portanto, às tecnologias digitais.

A sala de aula, tradicionalmente fundada na transmissão de "A" para "B" ou de "A" sobre "B", permanece alheia ao movimento das novas tecnologias comunicacionais e ao perfil do novo espectador. Para enfrentar o desafio de mudar essa tradição, o professor encontra no tratamento complexo da interatividade os fundamentos da comunicação que potenciam um novo ambiente de ensino e aprendizagem. [Silva, 2001, p. 08]

A interatividade, na verdade, está em tudo. É a abertura para mais e mais comunicação, mais e mais trocas, mais e mais participação. Tendo em vista a educação e o ambiente escolar, a interatividade deve estar presente na relação do professor-aluno-conhecimento, mas não como consequência da presença de novas tecnologias, mas como foco, como uma característica, um requisito, para a construção do conhecimento.

A interatividade só vai estar presente no ambiente escolar quando o professor propuser o conhecimento (e não apenas transmiti-lo), provocando 
situações, instigando discussões mais profundas e quando o aluno participar, de modo a intervir e modificar a mensagem que foi transmitida pelo educador. Enquanto a educação se basear apenas nessa transmissão/emissão, fundamentada há anos, ficará cada vez mais difícil criar e imaginar algo em cima do que foi dito.

A educação, por ser um processo de extrema importância, deve mudar ao longo do tempo, de acordo com o que é proposto para melhorar sua aplicação. Entretanto, para que isso ocorra de forma eficaz, é preciso que o educador acompanhe esse processo de evolução da educação. Ele deve adaptar-se ao novo mundo que se abre cada vez mais às tecnologias, pois essas tecnologias estão sendo aplicadas fortemente na educação. Caso contrário, não haverá a mínima afinidade necessária entre aluno e professor para que tenhamos 0 conceito "interatividade" sendo aplicado em sala de aula.

\subsection{Histórico do uso de novas tecnologias no processo educacional}

A história do uso de novas tecnologias na educação está intimamente ligada a história da humanidade, sendo assim, podemos considerar que a presença da tecnologia na educação data, de acordo com a história, de mais de 30 mil anos a.C., quando os homens primitivos escreviam e faziam desenhos e inscrições nas paredes das cavernas em que habitavam. Vários ensinamentos eram transmitidos entre os indivíduos da comunidade, como histórias e lições de caça, construindo assim uma situação de ensino e aprendizado já naqueles tempos. Percorrendo as linhas da História, encontramo-nos na Grécia Clássica, onde o surgimento e a ascensão da Filosofia socrática ficaram conhecidos como auge da sociedade da época. Filósofos como Sócrates não deixaram nada de material escrito, partilhando seus conhecimentos e pensamentos apenas pelo diálogo. 
Conforme evidenciado em levantamento realizado pela PUCPR em 2012, no artigo "Do quadro negro ao tablet", há na história da tecnologia na educação um grande lapso temporal entre o surgimento de avanços em outras áreas até o avanço no âmbito de ferramentas educacionais. O surgimento do papel, segundo Oliveira [2016], deu-se somente em torno do ano 105 d.C., uma lacuna de mais de seiscentos anos sem seu uso desde a época da filosofia grega. A técnica de transcrição manuscrita de livros e documentos é datada do ano de 356 d.C., um espaço de tempo razoável para este avanço. Já para a criação da imprensa houve um espaço de mais de mil anos, o que pode ser considerado um atraso no desenvolvimento das tecnologias para o melhoramento do processo educacional.

À medida que o tempo passava, o lapso temporal entre a criação de uma nova tecnologia e outra ficava ainda menor, de acordo com levantamento da PUCPR (2012). Menos de cem anos se deu entre a criação do quadro-negro e a publicação de livros em massa para uso na escola. Por exemplo, a quantidade de inovações que foram desenvolvidas, sejam elas funcionais ou não, também foi imensa se comparada à quantidade que era desenvolvida há trezentos anos.

Essa aceleração de criação de novos recursos deve-se a um fenômeno contemporâneo o qual se mostrou relevante na década de 80 , chamado de cibercultura [Levy, 1997], que representa a forma sociocultural advinda da interação entre a cultura e a sociedade com as novas tecnologias e mídias que vêm surgindo. Ela representa as relações entre os indivíduos no ambiente da internet, popularizando-a e tornando-a uma nova e incisiva forma de comunicação social, não apenas como ferramenta de trabalho ou estudo.

Porém cibercultura não é simplesmente uma cultura social dependente da tecnologia, mas, sim, uma comunidade que interage com a tecnologia e utiliza-se dela para estabelecer relações. Atividades simples como, inscrever-se em algum evento pela internet ou pagar uma conta no site do banco, são exemplos de formas como a cibercultura está inserida em nosso cotidiano. 
A presença das tecnologias na sala de aula é um dos exemplos de como a cibercultura é uma parte inerente ao nosso cotidiano. A utilização de power-point, projetores de imagens, computadores e outros recursos está se tornando cada vez mais necessária para melhoria da apreensão do conhecimento [Martinho \& Pombo, 2009], e aulas que necessitem de demonstrações utilizando vídeos e animações gráficas não seriam possíveis sem a existência dos mencionados recursos.

Estas tecnologias são, normalmente, introduzidas na escola como sinal de modernidade, abdicando-se do seu verdadeiro potencial. Professores são levados a utilizar as novas tecnologias sem que, na maior parte das situações, sintam estas como valor de mediação para as matérias que lecionam. Esta opção nos leva a um retrocesso a cada novo passo da tecnologia, tendo em vista que é utilizada sem foco no usuário e no processo de aprendizagem [Garcia, 2015].

O desafio que hoje se tem para o uso das Tecnologias de Informação e Comunicação para o Ensino de Ciências é o de conceber uma metodologia de ensino que rompa com a linearidade da educação tradicional (transmissiva, baseada no uso excessivo do livro didático no formalismo matemático etc.), e criar estratégias que levem os alunos a pensar, pesquisar, selecionar informações, recolher evidências, organizar os argumentos e apresentar conclusões. Essas estratégias nem sempre são fáceis de serem desenvolvidas e os motivos são diversos: a falta de material didático adequado, a formação inadequada de professores, o tempo excessivo de trabalho. [Fernandes, Rodrigues e Ferreira, 2015, p. 944] Grifos da autora

Com relação ao uso das redes sociais, convém retomar a maneira como foram introduzidas em nossas vidas. Com a popularização do acesso à internet por volta do ano 2000 , um novo tipo de serviço de comunicação, informação e a princípio de entretenimento - começou a ganhar força: são as chamadas redes sociais. Encontramos, atualmente, uma grande variedade de produtos nesse mercado, com alternativas que vão além do famoso Facebook e Twitter. Estudos, 
como o apresentado na figura 1, mostram que temos gasto cada vez mais tempo do nosso dia interagindo com outras pessoas por meio das redes sociais.

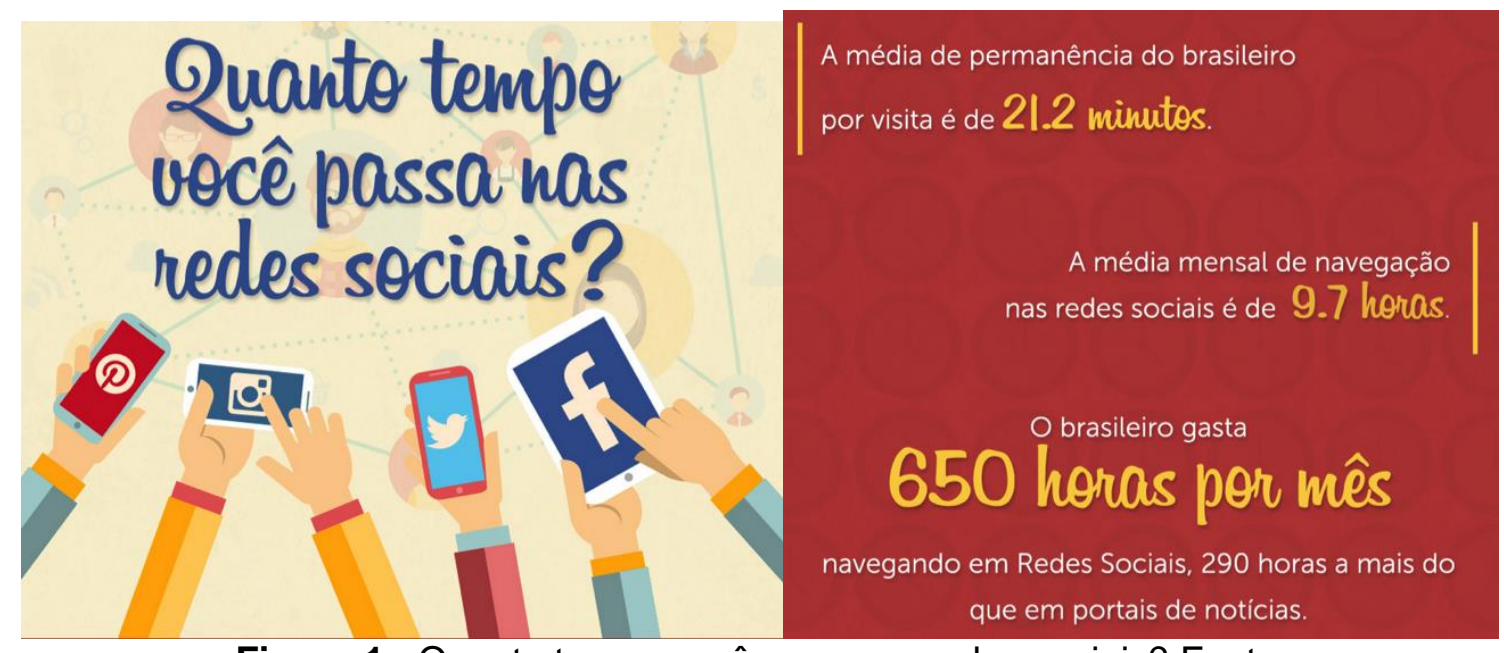

Figura 1 - Quanto tempo você passa as redes sociais? Fonte:

$<$ www.tecmundo.com.br/redes-sociais/81714-infografico-mostra-tempo-brasileirosgastando-redes-sociais.htm> Acesso em junho/2016

O que podemos observar, em muitas situações, é que se trata de uma imposição de fora para dentro, dessas novas tecnologias, em relação à escola. As redes sociais são, talvez, um dos exemplos mais recentes de como a escola precisa se readaptar aos novos espaços de discussão e aprendizagem, alheios à sua influência e que pode, digamos, deve ser aproveitado como plataforma potencial de apoio ao processo de ensino/aprendizagem.

$\mathrm{Na}$ era do conhecimento, deixar de reconhecer o outro na sua inteligência é recusar-lhe a sua verdadeira identidade social, é alimentar o seu ressentimento e a sua hostilidade, humilhação e frustração, de onde surge por vezes a violência. Em contrapartida, quando valorizamos o outro de acordo com o leque variado dos seus saberes, permitimos que se identifique de um modo novo e positivo, contribuímos para mobilizá-lo e para desenvolver nele sentimentos de reconhecimento que facilitarão, consequentemente, a implicação subjetiva de outras pessoas em projetos coletivos. As redes sociais podem contribuir, deste modo, para a mobilização dos saberes, o reconhecimento das diferentes identidades e a articulação dos pensamentos que fazem parte do todo. [Garcia, 2015, p. 26] 
Neste caminho, optamos pelo uso do Instagram, uma rede social que permite aos usuários transformar instantaneamente as fotos dos seus dispositivos eletrônicos [celulares] em imagens com apelo visual surpreendente, que podem ser compartilhadas rapidamente com a rede. As imagens podem ser compartilhadas também pelo twitter, facebook e forsquare. O Instagram foi lançado, em outubro de 2010, por Kevin Systrom e pelo brasileiro Mike Krieger [Santos e Santos, 2014].

Foi adquirido pelo Facebook, em abril de 2012, e tem aproximadamente 130 milhões de usuários ativos. Em 2013, adicionou a capacidade de postar vídeos curtos, em resposta ao crescimento do Vine um aplicativo de vídeos de 6 segundos criado pelo twitter. O Instagram é dedicado à experiência móvel e parte da sua evolução está relacionada à rápida adoção dos smartphones e de suas poderosas e potentes câmaras. De qualquer forma, atualmente é possível acessar à rede via Web e postar fotos diretamente do seu navegador.

Segundo, Salomon [2013], o uso do Instagram é maior entre os jovens do que entre os adultos, portanto, optamos pelo desenvolvimento de um modelo que utiliza esta rede social, como plataforma de aprendizagem em rede, visando a oportunidade de aproximação de professores e alunos num ambiente para além da sala de aula [Fraga, 2012].

Em 2014, um estudo realizado pelo departamento de ciências da computação, da Universidade do Arizona, sobre o escopo das postagens realizadas no Instagram mostrou a proporção entre as categorias e o tema das principais postagens. Da pesquisa extraímos o gráfico a seguir onde observamos que a maior parte das postagens está relacionada às atividades pessoais, não havendo qualquer menção a conteúdos de divulgação científica.

Nesse sentido, cabe reafirmar o papel essencial do professor e dos materiais de divulgação e/ou popularização da ciência na recontextualização dos conhecimentos científicos para o âmbito especificamente escolar. [Binsfeld e Auth, 2000, p. 02] 


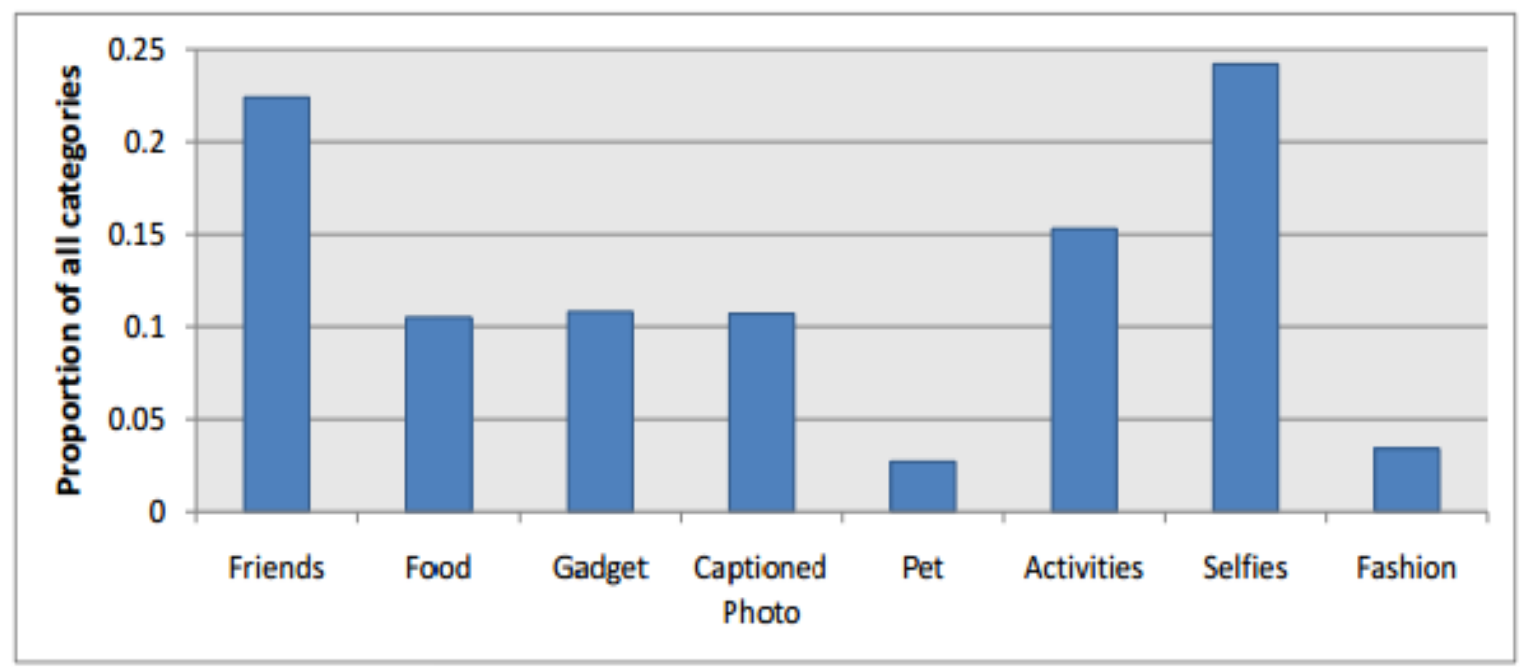

Gráfico 4 - Proporções e categorias. Fonte: <149.169.27.83/instagram-icwsm.pdf> Acesso em junho/2016

Tendo em vista essa necessidade e estando em consonância à forma de comunicação da geração dos estudantes de hoje, nesta proposta didática, optamos por inundar a rede com conteúdo científico associados aos fenômenos ópticos. Nossa intenção, era empoderar os jovens para que se sentissem parte do processo de construção do conhecimento, da aprendizagem em rede [Siemens, 2010] e agentes de divulgação científica.

Diante do acesso crescente a um vasto campo de informações pelas pessoas em geral e os estudantes em particular, não é mais tolerável à escola o papel de transmitir pacotes repetitivos de informações e/ou veicular novidades, de forma fragmentada. Cabe repensar cada vez mais os processos de formação, na perspectiva de contribuírem sistematicamente para o exercício da cidadania. [Binsfeld e Auth, 2009, p. 02]

$\mathrm{Na}$ sessão a seguir apresentamos um estudo a respeito das gerações e sua relação com as tecnologias digitais. 


\subsection{As Gerações e suas Tecnologias}

Entende-se o conceito de geração por diversas maneiras, com diferentes focos porque é uma definição ambígua e muito ampla para um único ponto de vista. Contudo, a mais adequada à proposta deste trabalho compreende-se como uma sincronização entre o curso da vida e experiências históricas de diferentes identidades no mesmo espaço, período de tempo e idade que vivem num contexto social semelhante.

Não há um parâmetro para medir a duração de cada geração, pois não é apenas uma sucessão biológica da anterior. Uma geração é caracterizada pelos pensamentos, fatos históricos marcantes de sua época, sociedade e tecnologia, esta última é, entretanto, o fator mais importante para se determinar uma geração [Feixa e Leccardi, 2010].

Estima-se que a cada trinta anos ocorra a mudança de geração. Todavia, com as mudanças do ritmo de vida e os aspectos da sociedade, esse tempo vem gradativamente se reduzindo tornando-se uma tendência para os próximos anos.

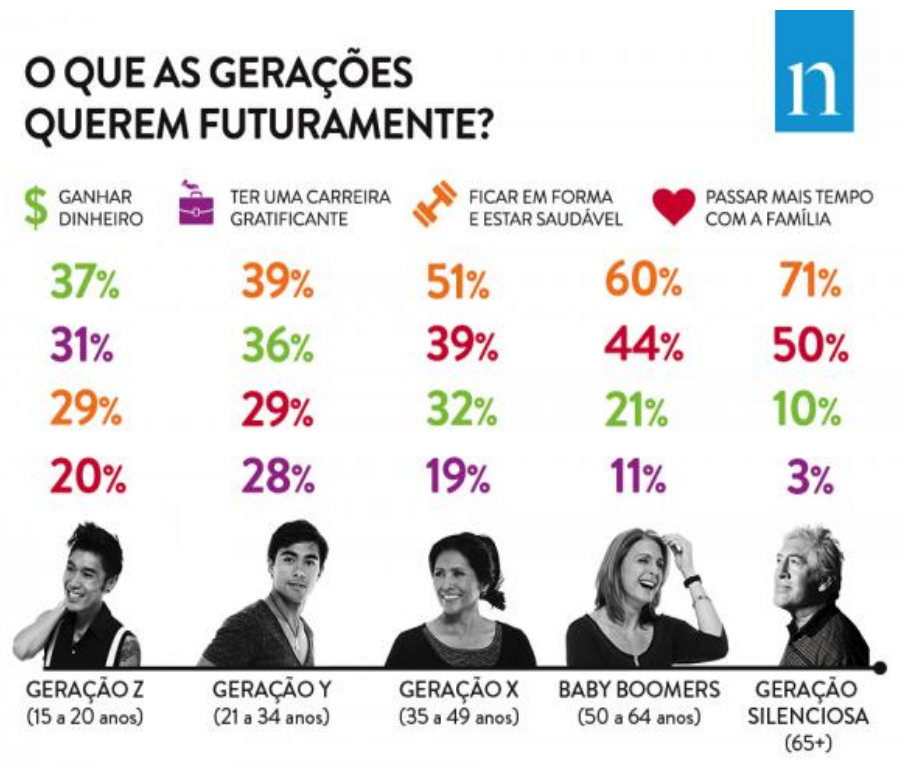

Figura 2 - Estilo de vida das gerações - Nielson Global [Nov/2015]. Fonte:

http://www.gazetadopovo.com.br/viver-bem/wpcontent/uploads/2016/02/12717958 11973472069424442367440151964926942 n600x503.png Acesso Junho/2016 
Suas transformações ocorrem e se desenvolvem pela interatividade de cada uma com as outras gerações contemporâneas a ela. Somadas ao tempo histórico, seu potencial de inovação tende a ser imensurável. Basicamente, porque se capta todas as transformações e as compreende tão rapidamente quanto a história permite.

Dessa maneira, o mercado tem como foco econômico o desenvolvimento da tecnologia, pois ela traz poder e riqueza para a sociedade, além de uma ferramenta para possibilitar a qualidade de vida e, portanto, se torna uma maneira de diferenciar as gerações. Ela é um facilitador de processos - envolvendo humanos e/ou objetos - que está sendo aplicado na sala de aula como uma fonte de novas dinâmicas educacionais e serve como integrador de conhecimentos que possibilita mudar o conceito de aula e educação para um conceito novo. Nessa nova concepção, espera-se que não haja mais um professor e um aluno, mas um agente transformador que promove, instiga a construção da consciência crítica das novas gerações sendo ambos protagonistas do processo educacional de modo que tudo isso esteja em consonância com a geração "Z", a mais impaciente que já existiu [Nielson, 2015].

A geração $Z$ é chamada dessa forma por conta da velocidade com que executam suas tarefas e atividades cotidianas, como zapear pela televisão, saltar da televisão para internet ou para o celular, estar sempre conectada nas redes sociais e pensar em várias coisas ao mesmo tempo. Por essa lógica, consegue acompanhar as mudanças desse mundo novo, que mudou tanto em pouco tempo, e se adaptar ao ritmo de produção e consumo diversificando suas atividades e lazer - de livros e amigos para computadores e internet. Esse fato é muito útil, sob a ótica de mercado, porque os jovens sabem manipular de maneira eficiente as novas ferramentas tecnológicas e trabalhar em rede, fatos que proporcionam uma possível melhora no desenvolvimento de empresas e na realização de tarefas.

$\mathrm{Na}$ imagem a seguir podemos observar as diferenças entre as gerações, Baby Boomer, X e Z. 


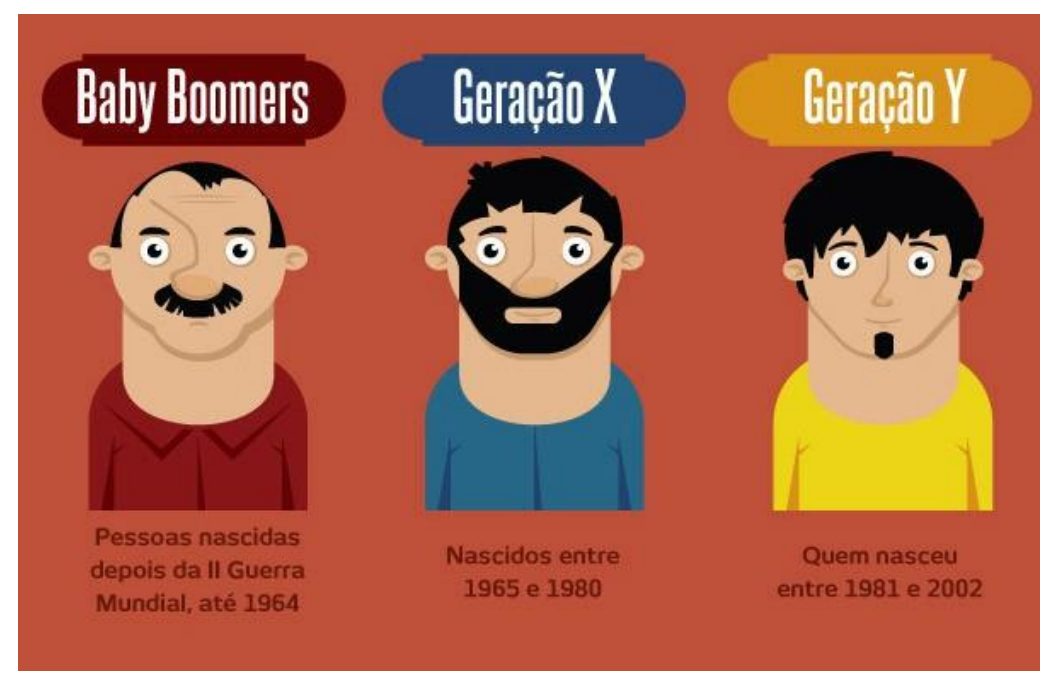

Figura 3 - Diferenças entre as gerações. Fonte:

http://lanyy.jusbrasil.com.br/artigos/180433691/a-grama-do-vizinho-nao-e-tao-verdequanto-voce-pensa-um-recado-para-a-geracao-z Acesso em Junho 2016

É claro que essas características não estão presentes em todos os jovens, mas são um conjunto de pontos de vista de outras gerações que as veem de tal maneira, pois possuem outros ideais e comportamentos próprios. Logo, se reflete o choque entre as diversas gerações presentes no atual tempo histórico e reforça o exercício à tolerância e ao respeito entre as diferenças, especialmente àquelas causadas pelo caráter etário/cultural.

Portanto, nada mais natural do que aplicar novas tecnologias ao processo educacional. Como a conectividade é uma das características principais dessa geração, isso tende a facilitar muito o processo ensino-aprendizagem. Porém, é importante ressaltar que isso não é garantia de que as tecnologias sozinhas possam resolver os problemas da educação, pois a geração $Z$ parece muito controversa às anteriores no que se refere aos valores e à maneira como se comporta nas redes sociais. Portanto, educar os novos jovens nesse ponto causa um impacto crucial no desenvolvimento das características sociáveis e comunicativas. Outras necessidades adjacentes são espaço e diálogo. A tríade atenção-espaço-diálogo se torna, portanto, essencial para o sucesso da inserção dos dispositivos móveis na escola nas escolas [Freire, 1968]. 


\title{
2. O USO DE TECNOLOGIA NA SALA DE AULA: UMA VISÃO CONTEMPORÂNEA.
}

\subsection{As tecnologias na sala de aula \& Processos de ensino e aprendizagem}

\begin{abstract}
É impossível aprender bem simplesmente sentado em uma palestra, ou mesmo simplesmente resolvendo exercícios. Mas nos nossos tempos modernos, temos tantos estudantes para ensinar que temos de tentar encontrar algum substituto para o ideal. ${ }^{4}$ [Feynman, 1963, p. 01].
\end{abstract}

A tecnologia no âmbito educacional consiste, basicamente, em aplicar recursos tecnológicos em prol de maior facilidade do desenvolvimento pedagógico e do acesso à informação. Na nossa realidade contemporânea, a tecnologia está em constante e acelerado desenvolvimento, assim como a tecnologia educacional. Contudo essas inovações trouxeram também um sério novo problema às salas de aula: como transformar a presença dos novos aparelhos tecnológicos [celulares, tablets, computadores e outros] em aproveitamento pedagógico e como direcionar favoravelmente o seu uso.

A grande conectividade da tecnologia também vem influenciando o uso de aparelhos nas salas de aula. Sempre conectados, os alunos se encontram suscetíveis às distrações oferecidas pela gama de opções de entretenimento na rede. Numa tentativa de resolver o problema, no Distrito Federal, desde maio de 2008, é proibido usar celular em sala de aula. A Lei Distrital no 4.131/20085 proíbe que os alunos liguem o aparelho em todos os colégios públicos e particulares. A lei também proíbe o uso de qualquer aparelho eletrônico capaz de armazenar e reproduzir arquivos de música, CDs e jogos, como MP3 players e videogames. Os

\footnotetext{
4 Tradução da autora.

${ }^{5}$ Lei 4.131 de 2 de maio de 2008, projeto da Deputada Eurídes Brito e sancionada pelo então governador José Arruda. Disponível em

<http://www.sinprodf.org.br/wp-content/uploads/2011/03/lei-n\%C2\%BA-4.131-de-02-demaio-de-2008.pdf. > Acesso em junho/2016
} 
equipamentos estão liberados, apenas, nos intervalos e no horário de recreio, desde que sejam utilizados fora da sala. Os alunos que desrespeitarem a lei terão de arcar com as decisões de cada unidade de ensino, que tem autonomia para lidar com o assunto.

A proibição do celular na sala de aula, por meio de uma lei, mostra o despreparo da escola e da comunidade docente em lidar com o desenvolvimento tecnológico, pois ao proibir o estudante de usar o aparelho em sala, estamos privando-o também do acesso a toda rede de aprendizagem que este dispositivo é capaz de proporcionar. Dessa forma, cabe ao professor orientar o uso dessas ferramentas para que sejam direcionadas ao desenvolvimento de habilidades cognitivas. A proposta mais recente da tecnologia educacional é: ao invés de tentar impedir o uso de aparelhos, principalmente computadores do tipo tablet, incorporar o seu uso às aulas, promovendo não só o acesso livre a informações, mas também a relação entre alunos (via e-mail, redes sociais), favorecendo a interatividade [Siemens 2004].

Esse novo modelo educacional propõe uma mudança nos papéis dos professores e dos alunos. Os professores não seriam mais a única fonte de informação, uma vez que o acesso irrestrito à rede se faz presente, mas assumiria seu papel de intelectual, referência em sua área de estudo e pesquisa, que orienta o processo de construção do conhecimento. Também, a função dos mestres seria a de mediar, de orientar o conhecimento e direcionar os conteúdos, dialogando com os alunos sobre o assunto ministrado. Os alunos, por sua vez, deixam de apenas receber informações passivamente e se tornam protagonistas de seu próprio aprendizado. Os alunos trocariam e selecionariam seus conhecimentos recém-adquiridos, sob a orientação do professor.

O professor deve compreender a interdependência existente entre indivíduos e grupos. A escola deve favorecer a prática das relações humanas, incentivando a livre comunicação, a cooperação e o auxílio mútuo. [Resende, 1999, p. 30] 
Todo ser humano, de alguma forma, busca o aprendizado. Desde pequenos são instigados pelo mundo e procuram entendê-lo de maneira única e singular [Freire, 1969]. O importante, no entanto, é desenvolver habilidades com relação à melhor maneira de aprender para poder atingir objetivos e alcançar sucesso ao longo da vida [Siemens, 2010].

Aprendizagem é um processo não linear no qual experienciamos alterações permanentes quanto aos aspectos intelectual, comportamental e às formas como nos relacionamos com o mundo [Fleury \& Fleury, 2001]. O estudante por si só busca o aprender, o professor deve procurar entender o universo desse estudante, e adaptar os seus métodos de ensino para que as habilidades desejadas sejam desenvolvidas de forma horizontal. O professor, agente intelectual, deve instigar o jovem à construção do conhecimento, deve gerar inquietação para que o estudante se perceba com vontade de aprender e busque o conhecimento além do professor [Freire, 1989]. Ao considerarmos o contexto atual, é relevante considerar que existe uma nova dimensão no aprendizado, a dimensão virtual, que está baseada em interações sociais, e definitivamente não pode ser ignorada [Franco, 2009]. Como o fator digital possui uma enorme relevância na sociedade, no âmbito desta investigação, procuraremos trabalhar com uma teoria de aprendizagem pertencente ao contexto da era digital, o conectivismo.

A teoria do Conectivismo [Siemens, 2004] apresentada por Siemens em 2004, no artigo "A Learning Theory for the Digital Age", parte da ideia de que o conhecimento está distribuído em redes, portanto não há sentido a ideia de transferência do conhecimento, visto que o conhecimento historicamente construído consiste em uma rede de ligações formada pela experiência e pela interação desenvolvida numa determinada sociedade [Araújo, 2010].

O conectivismo emerge, dessa forma, como uma teoria da aprendizagem para a era digital, na qual o conhecimento é construído segundo uma rede conectada. O fenômeno das ferramentas sociais, vem transformando o modo 
como o ser humano interage uns com os outros, com a informação e, finalmente, com o próprio conhecimento [Garcia, 2015].

Diante dessa nova teoria, sabemos que as interações com o mundo real e virtual se dão de diversas formas, a fala, a escrita, os textos imagéticos (fotos, gravuras...), ou seja, a multimodalidade - a linguagem verbais e não verbais constroem sentidos e percepções sobre o mundo e consequentemente constroem conhecimento. Apresentamos a seguir uma tabela que registra a contribuição dos nossos sentidos para aprendizagem.

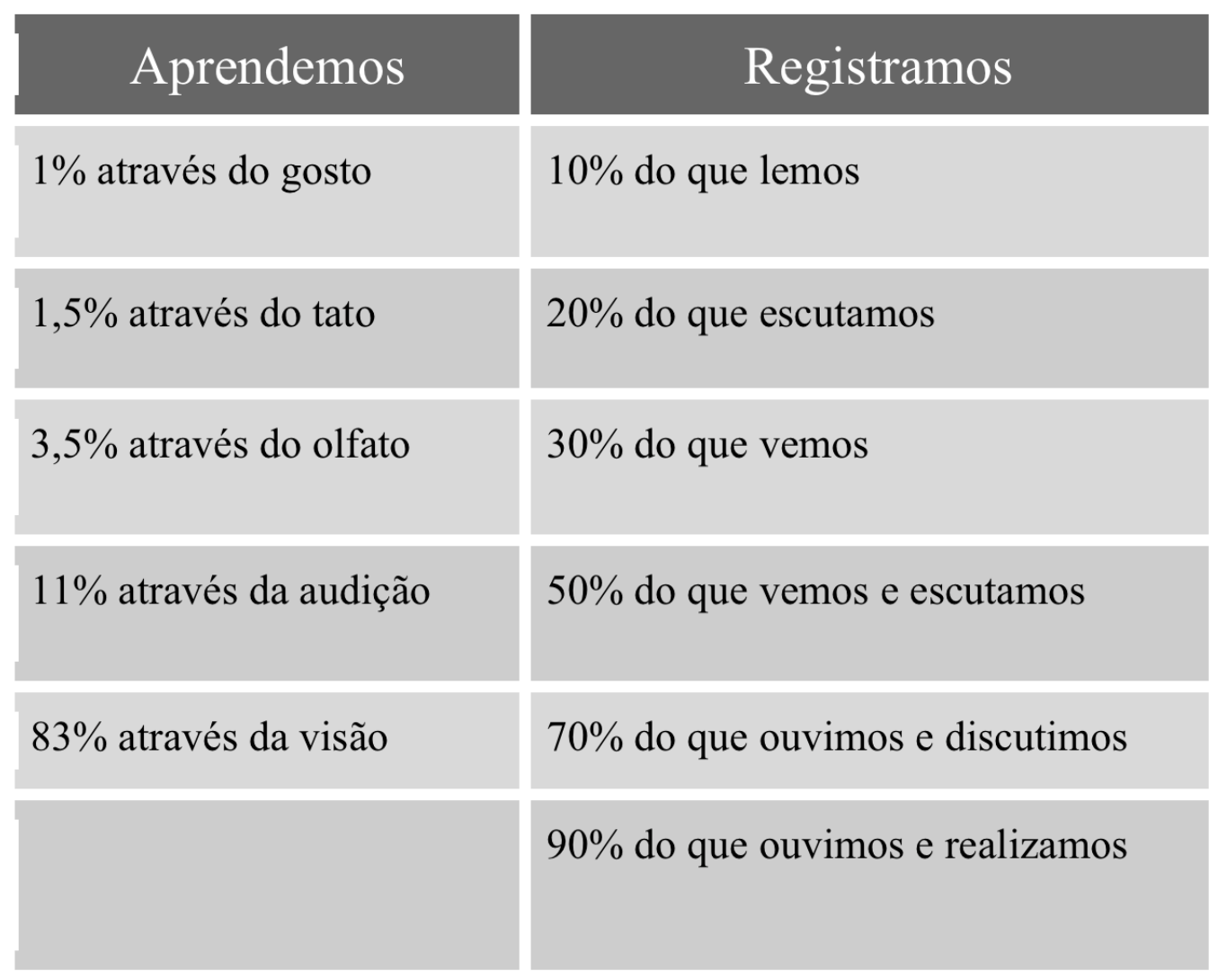

Quadro 2 - Didática em perspectiva - Carlos A. Rezende, p. 47 
MODALIDADE

DE ENSINO
DADOS RETIDOS

DEPOIS DE 3

HORAS
DADOS RETIDOS

DEPOIS DE 3 DIAS

$10 \%$

$20 \%$

$65 \%$

\begin{tabular}{|c|}
\hline $10 \%$ \\
\hline $20 \%$ \\
\hline $65 \%$ \\
\hline
\end{tabular}

Visual e oral simultaneamente

$70 \%$

$72 \%$

$85 \%$

Quadro 3 - Didática em perspectiva - Carlos A. Rezende, p. 47

Considerando esta perspectiva adaptamos os oito princípios do conectivismo [Siemens, 2004] para:

\begin{tabular}{|c|c|}
\hline NÚMERO & PRINCÍPIO \\
\hline 1 & Aprendizagem e conhecimento surgem na diversidade de opiniões. \\
\hline 2 & $\begin{array}{l}\text { Aprendizagem é um processo não linear que conecta pontos } \\
\text { especializados ou fontes de informação. }\end{array}$ \\
\hline 3 & Aprendizagem pode existir em mecanismos não humanos. \\
\hline 4 & $\begin{array}{l}\text { A capacidade de aprender mais adquire maior importância do que } \\
\text { aquilo que sabemos atualmente. }\end{array}$ \\
\hline 5 & $\begin{array}{l}\text { Fomentar e manter ligações é fundamental para auxiliar a aprendizagem } \\
\text { contínua. }\end{array}$ \\
\hline 6 & $\begin{array}{l}\text { A capacidade de ver ligações entre áreas de saber, ideias e conceitos é } \\
\text { uma competência fundamental. }\end{array}$ \\
\hline 7 & $\begin{array}{l}\text { O conhecimento atualizado e preciso é objetivo de todas as atividades } \\
\text { de aprendizagem conectivistas. }\end{array}$ \\
\hline 8 & $\begin{array}{l}\text { Tomar decisões é por si só um processo de aprendizagem. Escolher o } \\
\text { que pretendemos aprender e o significado da informação que nos chega } \\
\text { é levado em consideração no contexto de uma realidade em constante } \\
\text { mudança. O que agora é aceito como verdade, amanhã poderá estar } \\
\text { errado, devido a alterações nas informações experienciadas e coletadas } \\
\text { que afetam a tomada de decisão. }\end{array}$ \\
\hline
\end{tabular}

Quadro 4 - Princípios do conectivismo adaptado pela autora. [Siemens 2004] 
Dessa forma, não nos parece conveniente continuar a pensar 0 conhecimento (nem a sua construção) enquanto propriedade exclusiva e isolada de um único indivíduo. Por conseguinte, a colaboração parece emergir num meio caracterizado essencialmente pela nossa capacidade de conexão com outros indivíduos e com a rede [Garcia, 2015].

Uma outra análise que se pode fazer, no contexto do conectivismo, está ligada ao papel do professor, ou a falta deste que, ainda assim, segundo Siemens [2004], continuará a desempenhar um papel fundamental no processo de ensino/aprendizagem. No entanto, nos parece que o professor precisará adaptar a sua intervenção para colaborar na construção da rede de conhecimentos, bem como, passar para o papel de designer das oportunidades de aprendizagem, sendo da sua responsabilidade o desenho dos processos de ensino [Garcia, 2015].

Caberá ao professor ainda demonstrar aos seus estudantes como diferenciar informação científica de propaganda [Siemens, 2004]. Ou seja, será da responsabilidade do professor a coconstrução da rede de aprendizagem com os estudantes. Redes que deverão se manter ao longo da sua vida, como forma de responder de forma criativa aos problemas que encontrarem, e a de permanecer em contínua formação.

Seja por questões sociais ou de mercado, há uma demanda crescente pela formação de profissionais que tenham conhecimentos sólidos sobre conteúdos específicos e possuam habilidades e competências associadas ao trabalho colaborativo, discussão de ideias e metacognição. [Araújo, Mazur, 2013, p. 362-384]

Para compreender a estrutura técnico-didática utilizada neste estudo, vamos apresentar a seguir o TPACK, um modelo criado para ajudar professores na incorporação de novas tecnologias ao ensino. 


\subsection{TPACK - Conhecimento Tecnológico, Pedagógico e de Conteúdo}

TPACK a sigla em inglês para Technological Pedagogical Content Knowledge - em tradução livre, Conhecimento Tecnológico, Pedagógico e de Conteúdo - é um modelo teórico formulado com base nas ideias de Shulman ${ }^{6}$, para entender e descrever os tipos de conhecimentos necessários a um professor para a prática pedagógica efetiva em um ambiente de aprendizagem equipado com tecnologia. TPACK não é uma ideia nova, nem é propriedade de ninguém. Uma série de outros estudiosos têm argumentado que esse conhecimento sobre a tecnologia não pode ser tratado como livre de contexto, e que um bom ensino exige uma compreensão de como a tecnologia se relaciona com a pedagogia e o conteúdo. O quadro TPACK está ganhando popularidade entre os pesquisadores e estudiosos [Mishra e Koehler, 2006].

Para compreender a importância desta integração à atividade pedagógica vamos nos remeter a um estudo realizado por Ching Sing Chai et al, em 2013, que analisou 74 artigos em revistas que investigam a integração e transformação que professores precisam passar para utilização eficaz das tecnologias nas salas de aula.

Em forma de quadro, o TPACK aborda o problema decorrente da excessiva ênfase no conhecimento específico da matéria/área em muitos cursos de licenciatura. A análise realizada pelos autores indica que o uso do TPACK provoca

\footnotetext{
${ }^{6}$ Lee S. Shulman (nascido em 28 de setembro de 1938) é um psicólogo educacional que tem contribuições notáveis para o estudo de ensino, avaliação do ensino, nos campos da medicina, ciência e matemática. Ele é professor emérito da Stanford Graduate School of Education, ex-presidente da Fundação Carnegie para o Avanço do Ensino, ex-presidente da American Educational Research Association, e o destinatário de vários prêmios que reconhecem a sua pesquisa educacional. De 1963 a 1982 , Shulman era um membro do corpo docente da Universidade Estadual de Michigan, onde fundou e co-dirigiu o Instituto de Pesquisa sobre Ensino. Entre suas muitas realizações, Shulman é creditado com popularizar a frase "conhecimento pedagógico do conteúdo" (PCK). Ele recebeu o Prêmio Grawemeyer para o seu livro de 2004 The Wisdom of Practice: Ensaios sobre ensino, aprendizagem e aprender a ensinar. Fonte: <https://en.wikipedia.org/wiki/Lee_Shulman>
} 
resultados positivos quanto ao aumento da capacidade dos professores para integrar as tecnologias para a prática educacional. Além disso, perceberam que existem muitas lacunas no ensino e que o quadro TPACK pode ser empregado para facilitar as mudanças na educação. Entre elas o artigo destaca a necessidade de um estudo sobre a concepção de aprendizagem dos alunos com o uso de tecnologia e a utilização cruzada do TPACK com outros enquadramentos teóricos relacionados com o estudo da integração da tecnologia na escola, tal como abordaremos nesta dissertação.

A imagem a seguir apresenta o quadro TPACK. No centro do quadro TPACK, está a complexa interação de três formas primárias de conhecimento: Conteúdo (CK), Conhecimento Pedagógico (PK), e Tecnologia (TK). A abordagem TPACK vai além dessas três bases de conhecimento isoladas.

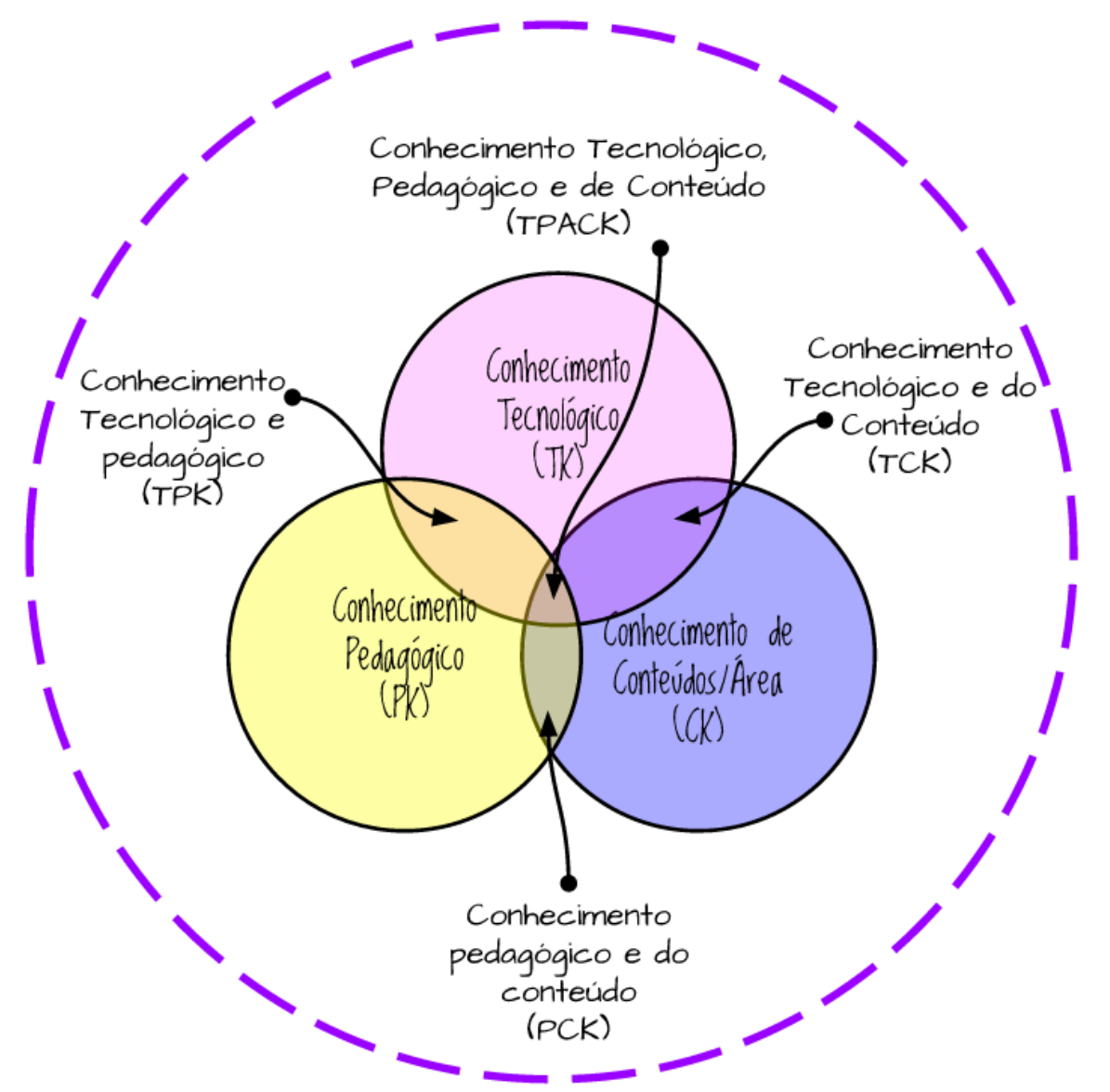

Figura 4 - Quadro TPACK. Fonte:<tpack.org> Tradução da Autora. 
Há de se ressaltar que não há hierarquia entre os conhecimentos, eles são considerados horizontais em termos de importância cognitiva. O diferencial do TPACK está na interligação dessas bases em três novos tipos de conhecimento que se apresentam nas intersecções, o que representa quatro novas estruturas de conhecimento a serem desenvolvidas pelos professores no uso de novas tecnologias na educação.

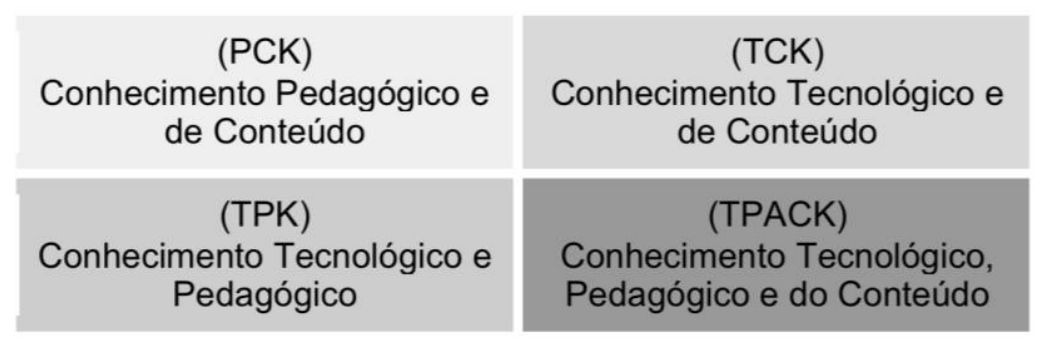

Quadro 5 - Novas habilidades a serem desenvolvidas pelos professores no uso de novas tecnologias na sala de aula. Fonte: <tpack.org>

A integração efetiva de tecnologias aos processos pedagógicos em torno de um assunto específico requer o desenvolvimento do relacionamento dinâmico e horizontal entre estes componentes de conhecimento situados em seus contextos educacionais. Caberá aos professores construir as trilhas de aprendizagem adequadas ao nível de ensino, à série e aos fatores específicos da escola para garantir que cada situação seja única. É importante ressaltar que as combinações de conteúdo, tecnologia e pedagogia serão aplicadas de forma diferente para cada professor em cada curso ou aula que for preparar. Para Fernandes e Rodrigues, ao construir trilhas de aprendizagem permeadas pela tecnologia

O professor deixa de ser o transmissor do conhecimento (como é no ensino conhecido como tradicional) e torna-se o gestor do processo de construção do conhecimento do aluno. Para isso, o professor de Ciências necessita ter um alto nível de competências, em que são requeridos conhecimentos científicos, pedagógicos e tecnológicos sobre o conteúdo. [Fernandes, Rodrigues, 2015, p. 957] 
Nesta dissertação optamos por usar estratégias de adoção da tecnologia de forma a personalizar o ensino e desenvolver a inteligência coletiva por meio das atividades propostas. Dessa forma, a proposta didática adotada para este projeto foi elaborada para levar os estudantes a:

\begin{tabular}{|c|c|}
\hline $\begin{array}{c}\text { Explicar a ocorrência de fenômenos } \\
\text { ópticos. }\end{array}$ & $\begin{array}{c}\text { Fotografar um fenômeno óptico utilizando } \\
\text { a câmera do celular ou uma máquina } \\
\text { fotográfica. }\end{array}$ \\
\hline $\begin{array}{c}\text { Construir e aplicar conceitos das várias } \\
\text { áreas do conhecimento para a } \\
\text { compreensão de fenômenos naturais e da } \\
\text { produção tecnológica. }\end{array}$ & $\begin{array}{c}\text { Relacionar informações, representadas de } \\
\text { diferentes formas, e conhecimentos } \\
\text { disponíveis em situações concretas, para } \\
\text { construir argumentação consistente. }\end{array}$ \\
\hline $\begin{array}{c}\text { Contribuir com a divulgação científica, ao publicar fotos de fenômenos ópticos em uma } \\
\text { rede social. }\end{array}$ \\
\hline
\end{tabular}

Quadro 6 - Objetivos do projeto.

Para compreender esse processo de introdução das ferramentas associadas ao conteúdo e às estratégias pedagógicas apresentamos a releitura do quadro TPACK, adotada neste estudo. 


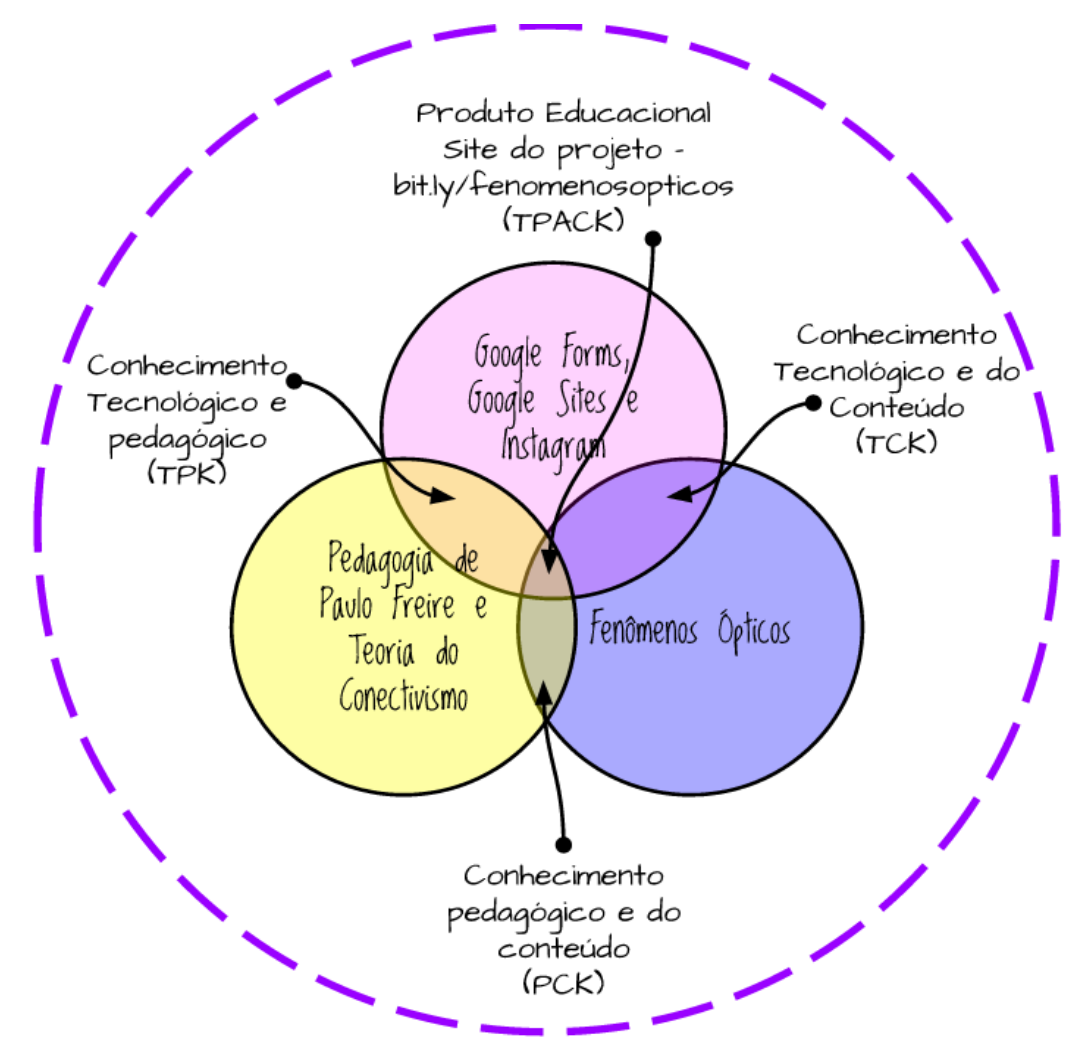

Figura 5 - Quadro TPACK para o projeto Fenômenos Ópticos. Adaptado de $<$ tpack.org>

Esta releitura nos mostrar a relação horizontal entre as três bases do conhecimento de forma a privilegiar as múltiplas habilidades dos estudantes. $\mathrm{Na}$ seção a seguir, vamos apresentar o modelo SMAR, para compreender o grau de utilização das ferramentas neste estudo.

\subsection{O Modelo SMAR}

A aprendizagem móvel, ou mLearning, em inglês, é definida como uma forma de aprendizagem personalizada e conectada por meio da utilização de um dispositivo móvel. A incorporação dessas novas ferramentas ao ensino, é feita gradativamente e precisa ser avaliada conforme vão sendo desenvolvidas [Puentedura, 2003]. Esses métodos de ensino têm sido pouco utilizados no Brasil e mostram-se desconhecidos da grande maioria dos professores. [Araújo e Mazur, 2014] 


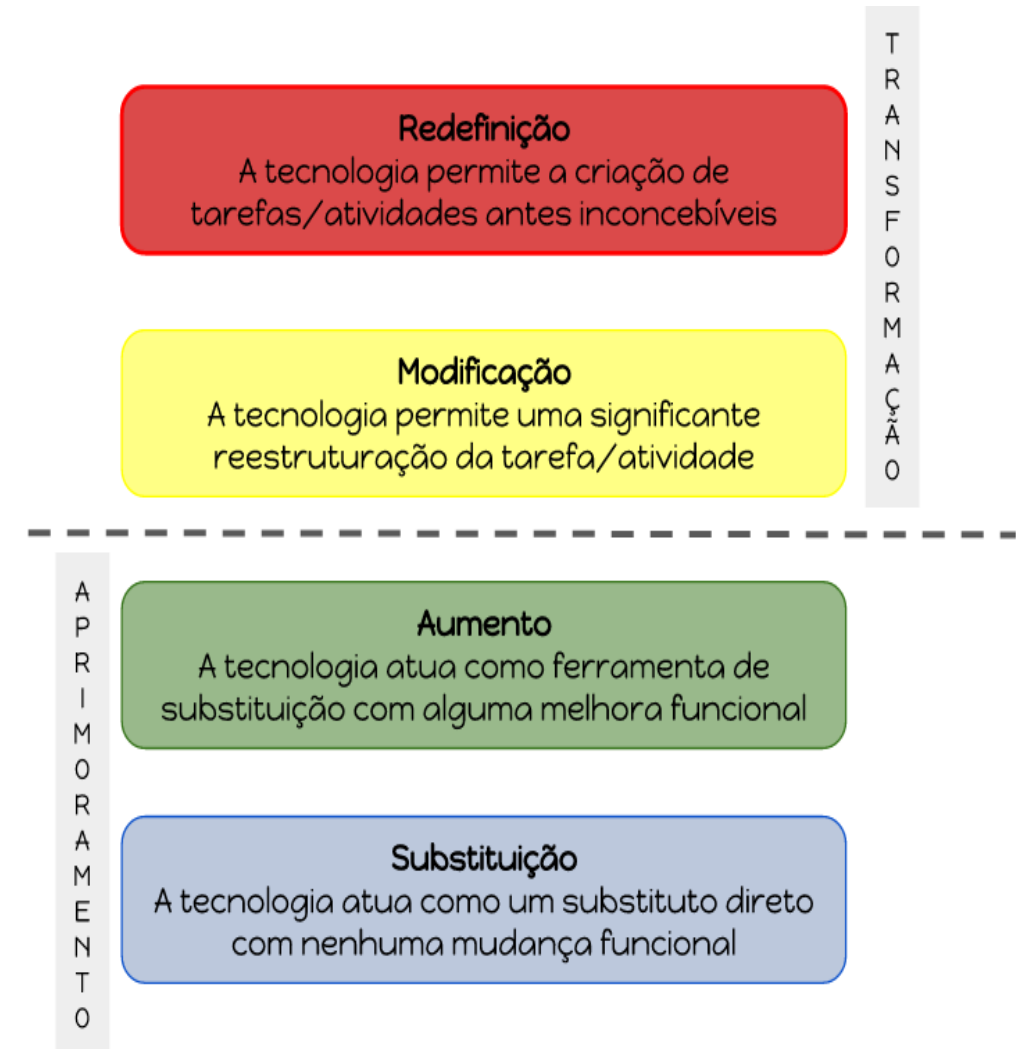

Figura 6 - Modelo SMAR de utilização da tecnologia [Puentendura, 2013].

Tradução da autora

O Modelo SAMR - sigla em inglês para, substituição, aumento, modificação e redefinição - é uma matriz que auxilia educadores na avaliação do uso de novas ferramentas na sala de aula. O modelo apresentado por Puentendura funciona como se fosse uma escada, a linha pontilhada representa a diferença entre o uso das ferramentas para aprimoramento das estratégias e consequente transformação. Esta transformação exige um nível mais alto de habilidades cognitivas, tais como analisar, avaliar e criar, que são habilidades exigidas no ensino do século 21 (PNEM). Nesta proposta didática, procuramos trabalhar em todos os degraus até chegar ao topo. O esquema a seguir apresenta este aprimoramento e transformação. 

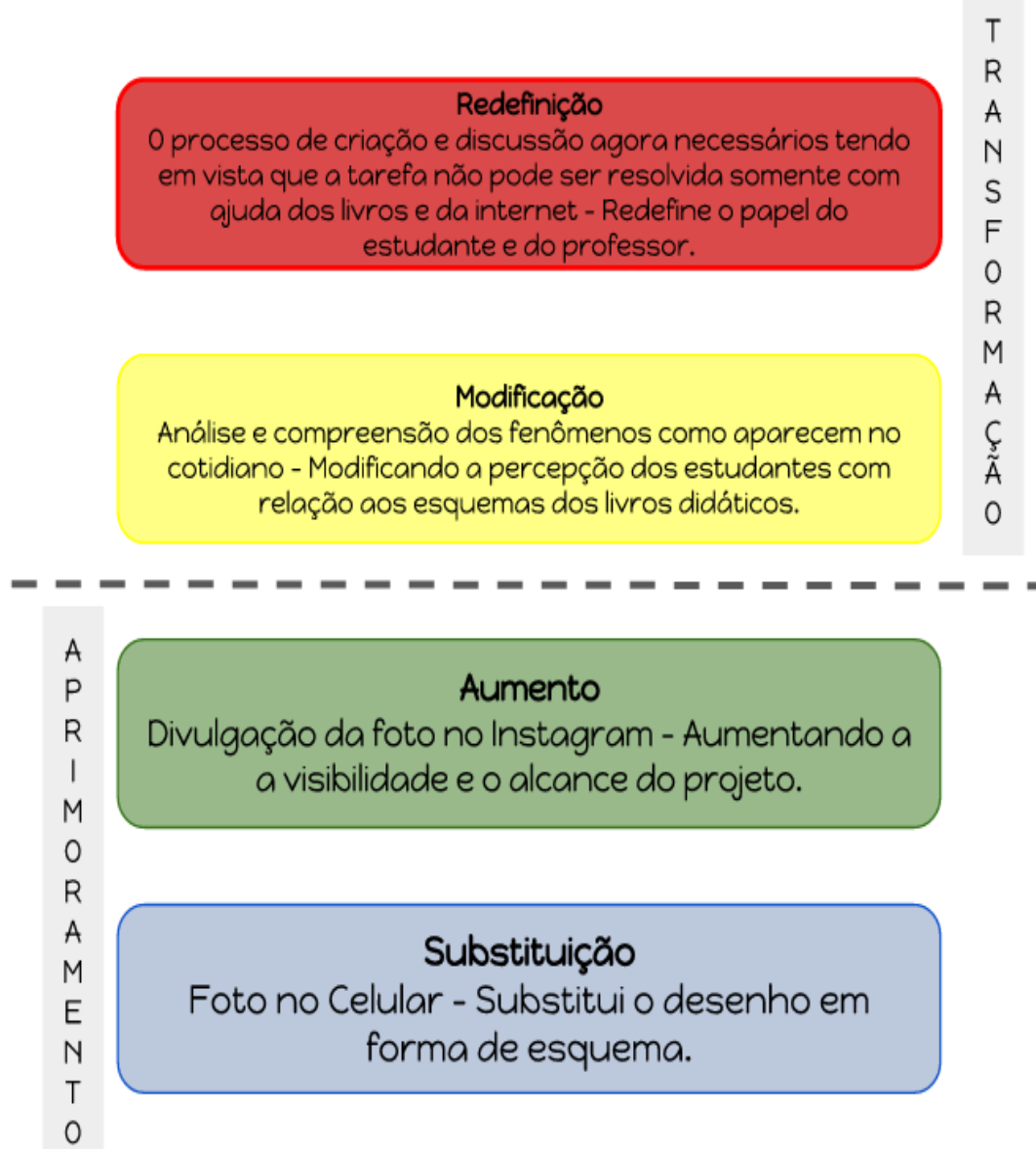

Figura 7 - Modelo SMAR de utilização da tecnologia [Puentendura, 2013] sob o ponto de vista da aprendizagem. Tradução e adaptação da autora

O Quadro mostra todo o processo de reestruturação das estratégias didáticas quando as tecnologias são introduzidas na sala de aula, o celular ou qualquer outro dispositivo móvel que se possa utilizar nesta proposta didática, passa a ser muito mais do que um espaço para devaneios e dispersão, tornandose um verdadeiro estúdio de aprendizagem. Nele o estudante pode além de tirar a foto para o projeto, editá-la e publicá-la, fazer uma pesquisa sobre o tema, discutir pelo WhatsApp com seus colegas a respeito do assunto, agendar reuniões e por fim, apresentar o seu produto final, mostrando todo o seu potencial para criação, cooperação e aprendizado. De acordo com Araújo e Mazur estratégias como as 
adotadas nesta proposta didática são importantes porque auxiliam os professores a:

Incentivar a adoção de um modelo de ensino que valorize o tempo em sala de aula, destinando-o para a aprendizagem ativa dos conteúdos por parte dos alunos, e não quase exclusivamente para transmissão de informações. [Araújo, Mazur, 2013, p. 365]

A substituição do esquema disponível nos livros para a foto no celular é apenas a primeira etapa da proposta, em seguida, é perceptível, o aumento das possibilidades de coconstrução do conhecimento e de divulgação científica quando a foto é publicada em uma rede social que também pode ser rica fonte de informação [Melo, 2014].

A partir deste ponto, os muros da escola são deixados para trás, o que antes era um projeto que pertencia somente a comunidade acadêmica, agora, faz parte da rede mundial de computadores, ou seja, a ampliação do impacto desta proposta didática está para além do espaço da sala de aula e da escola. A próxima etapa está na modificação que a proposta pode provocar na atividade solicitada, o que antes era estudado por meio de esquemas de forma sintética, passa a fazer parte do cotidiano dos jovens, pois os fenômenos ópticos não se resumem a uma mera geometrização e vão além das regras e definições. Além disso, os alunos possuem conhecimentos prévios a partir do que já vivenciaram [Albuquerque et al., 2015].

Por fim, o quadro mostra a ressignificação do papel do professor e do aluno na apresentação do projeto. Ao estruturar uma atividade como a que estamos a propor nesta dissertação, o professor passa a ter o papel de designer de aprendizagens, ou seja, o seu trabalho consiste em desenhar estruturas didáticas que permitam aos jovens o desenvolvimento da sua autonomia acadêmica, tornando-os protagonistas do seu processo de aprendizagem. Neste contexto, a aula expositiva perde espaço, sendo utilizada somente quando requerida pelos jovens para compreender alguma etapa do processo. Neste novo espaço que se 
abre o professor passa a ter o papel de consultor e de orientador no caminho trilhado pelos estudantes [Gabriel, 2013].

Ao analisar o modelo SAMR, sob a óptica do professor, perceberemos que a transformação é tão grande ou até maior do que para o aluno, vamos analisá-la no quadro a seguir.

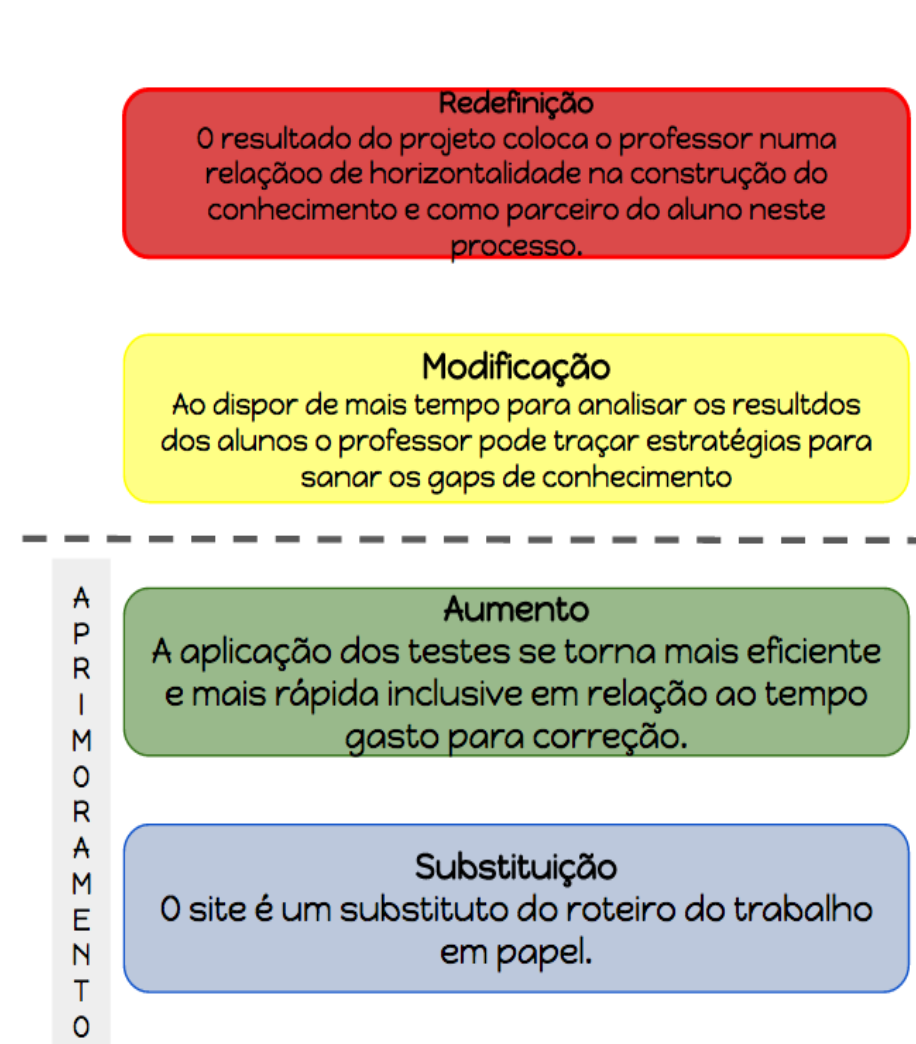

Figura 8 - Modelo SMAR de utilização da tecnologia [Puentendura, 2013] sob o ponto do trabalho docente. Tradução e adaptação da autora

Ao analisarmos o quadro, sob o ponto de vista do educador, percebemos que este processo também acontece de forma gradual, partindo do aprimoramento das atividades elaboradas até a completa transformação da sala de aula. Neste contexto, convém ressaltar a importância da capacitação docente no uso de novas ferramentas na sala de aula, inclusive nos cursos de licenciatura [Ferracioli e Sampaio, 2001] 
$\mathrm{Na}$ primeira escala do modelo, percebemos o site apenas como um substituto do roteiro que antes era entregue em papel. No entanto, vale ressaltar que nesta forma de apresentação há espaço para a introdução de vídeos e hiperlinks para complementação curricular, o que antes não era possível. Em segundo lugar, percebemos que o uso das novas tecnologias agiliza o processo de aplicação e correção das atividades, o que demanda menos tempo do professor, que, em terceira escala, pode analisar os resultados para fazer as intervenções de conteúdo que julgar necessárias, agora de forma completamente adaptada às demandas dos estudantes, esta modificação só pode ser proporcionada com a introdução das novas estratégias entrelaçadas às novas tecnologias.

Essa transformação leva à escala mais alta dos processos cognitivos, tais como, o desenvolvimento do pensamento crítico com relação as informações que encontram na rede, a criatividade, a cocriação, a comunicação e o desenvolvimento da inteligência coletiva, provocando uma significativa ressignificação do papel do professor e do aluno na sala de aula.

\section{REFERENCIAL TEÓRICO}

$\mathrm{Na}$ abordagem escolhida para este projeto, devemos observar que os processos de ensino/aprendizagem eficientes são, normalmente, elaborados por professores com um repertório variado de estratégias pedagógicas, bem como dependem da sua capacidade de ressignificação sobre o seu próprio trabalho. É imperativo ressaltar que as teorias mais aceitas, tais como, o Behaviorismo, cognitivismo e construtivismo foram desenvolvidas na era analógica, desconsiderando, portanto, a influência digital no aprendizado [Garcia, 2015].

Todavia, como não é possível abordar todos os pesquisadores que nos influenciaram nesta caminhada, optamos, neste momento, por nos dedicar aos temas geradores de Paulo Freire, não só por causa da sua importância para educação brasileira, mas por conta da sua preocupação a respeito do universo do 
aprendiz. Ao escolher uma rede social como ferramenta de aprendizagem mergulhamos no mundo da geração $Z$ e sabendo que a fotografia faz parte do cotidiano dos alunos desta geração [Karwatzki e Blauth, 2015] podemos aproveitar essa maneira de ver o mundo em favor da aprendizagem.

Analisando a concepção de Freire a respeito dos métodos tradicionais de ensino, que ele classifica como concepção bancária da educação, ou seja, aulas normalmente voltadas para a transmissão de conhecimentos e conteúdos e que essa escola acaba por ser mais um instrumento de opressão, percebemos 0 quanto é necessário romper barreiras. Um educador para novas habilidades intelectuais deve evitar o processo de reprodutivismo que em geral é alienante e gera uma visão distorcida da realidade. Consideramos então que o professor é o profissional mais habilitado a revolucionar processos de ensino e aprendizagem na escola, ele, segundo Freire deve estar a serviço da libertação. Afinal de contas, ninguém educa ninguém, ninguém educa a si mesmo, os homens se educam entre si, mediatizados pelo mundo [Freire, 1974].

Ao evitar ser apenas um transmissor do conhecimento e a trabalhar com estratégias que motivem a discussão na sala de aula, o professor rompe com a ideia de que a escola está distante da vida e que os conteúdos apreendidos nos servem apenas para passar nos testes e vestibulares. Os jovens, então, passam a desenvolver novas habilidades e competências relacionais e cognitivas.

A ideia do projeto foi concebida de forma a mostrar para o estudante que existe um mundo repleto de informações e fenômenos e que ele, aluno, já tem uma visão sobre esses fenômenos, enquanto, o professor também tem as suas ideias sobre aqueles tópicos, ou seja, ambos dominam o conhecimento de alguma forma, e quando eles discutem entre si todos os elementos e fatores associados ao tema, podem juntos construir uma explicação coerente para os fenômenos que ocorrem na natureza. Dessa maneira, professor aprende com aluno e aluno aprende com professor, numa relação horizontal, sem autoritarismo, mas com diálogo e autoridade cognitiva [Albuquerque et al., 2015]. 
Este projeto foi desenvolvido, pautado nas ideias de Paulo Freire e na teoria do conectivismo [Siemens, 2004], para desenvolver novas habilidades e competências a respeito dos fenômenos ópticos. Esta estrutura de pensamento está apresentada no esquema a seguir.

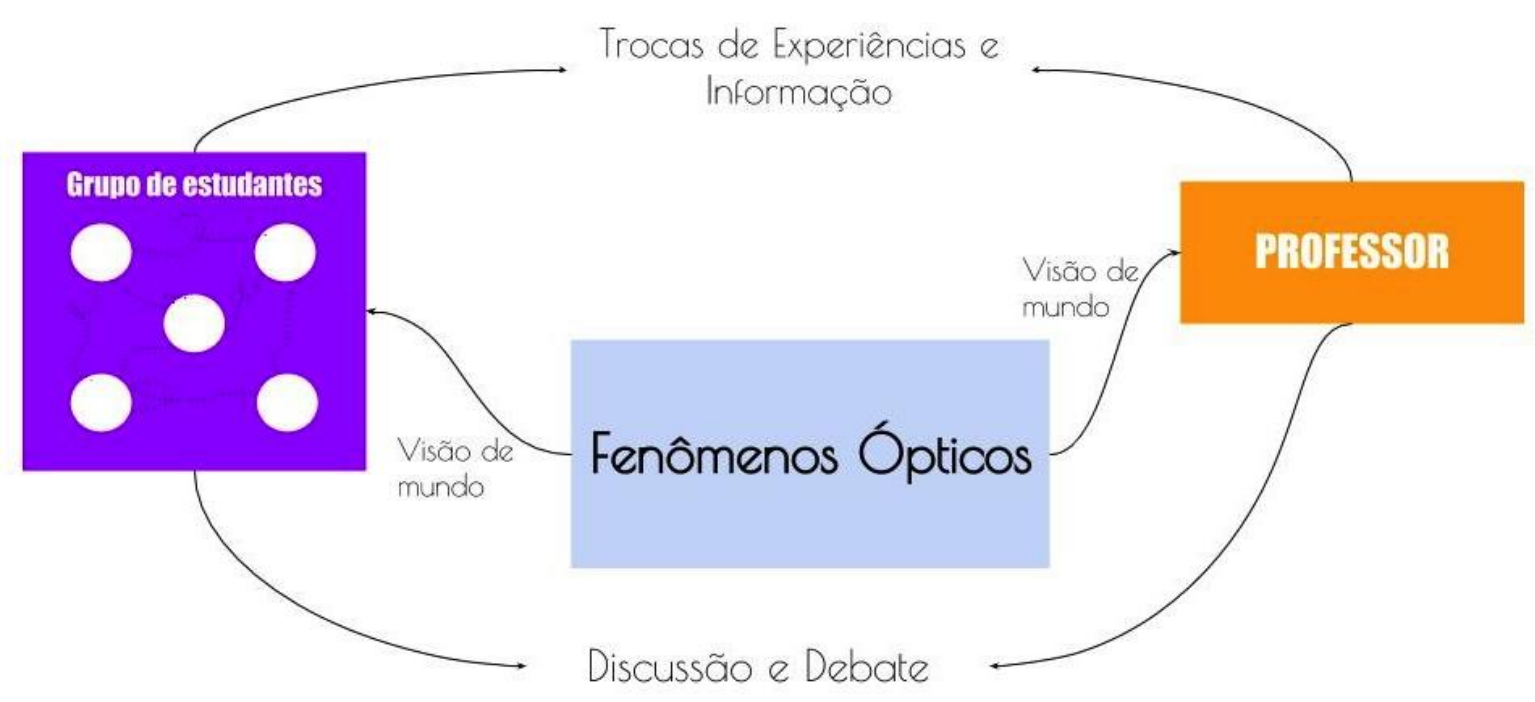

Figura 9 - Diagrama da concepção Freireana aplicada ao ensino de Física.

Segundo Freire [1974, p. 48], Fonte: Autora

O que temos de fazer, na verdade, é propor ao povo, através de certas contradições básicas, sua situação existencial, concreta, presente, como problema que, por sua vez, o desafia e, assim, Ihe exige resposta, não só no nível intelectual, mas no nível da ação.

[...] para que haja comunicação eficiente entre eles, é preciso que educador e político sejam capazes de conhecer as condições estruturais em que o pensar e a linguagem do povo, dialeticamente, se constituem.

$\mathrm{Na}$ figura 9, podemos perceber as interações que se dão, ao explorar a pedagogia dialógica de Paulo Freire, na realidade, o que observamos é que a aula tradicional perde espaço e que se abre para a criação de possibilidades diversas de aprendizagem em rede. 
Se de fato as aulas expositivas não estão entre os principais fatores que nos auxiliam a desenvolver as competências e habilidades que nos são caras, o que justifica ainda 0 investimento maciço de tempo e energia dispensados a elas? Em parte, talvez possa ser explicado por tradição. Fazia o maior sentido em outros tempos, quando as informações eram raras e o professor era, antes de mais nada, um erudito, que ele investisse em ditar ou copiar no quadro o que estava em suas anotações, ou em livros de difícil acesso. Desse modo, cada aluno seria capaz de ter uma cópia para si dos materiais.

Entretanto, o que justifica ainda esse modelo de ensino, claramente voltado para a disseminação de informações, quando poucas coisas são tão baratas e acessíveis hoje quanto a informação? Seja através da internet, de livros didáticos distribuídos gratuitamente ou de materiais fotocopiados, nunca foi tão fácil se informar. Talvez em algumas regiões carentes esse modelo, em certo grau, ainda faça sentido, mas está longe de ser o ideal naquelas que atingiram condições razoáveis de infraestrutura. Independentemente, o foco do ensino hoje deveria estar voltado para o compartilhamento e negociação de significados, sendo esse o "novo" papel do professor. [Araújo e Mazur, 2013, p. 380]

Além do diagrama apresentado na figura 9, convém analisar a estrutura das salas de aula quando dispostas para o ensino por meio dos métodos tradicionais (bancário) e quando dispostas durante aulas que utilizam as metodologias ativas de forma a proporcionar uma relação mais dialógica com o professor [Neto, 1983]. A figura a seguir esquematiza os dois casos. 


\section{Métodos Tradicionais}

\section{Métodos Ativos}

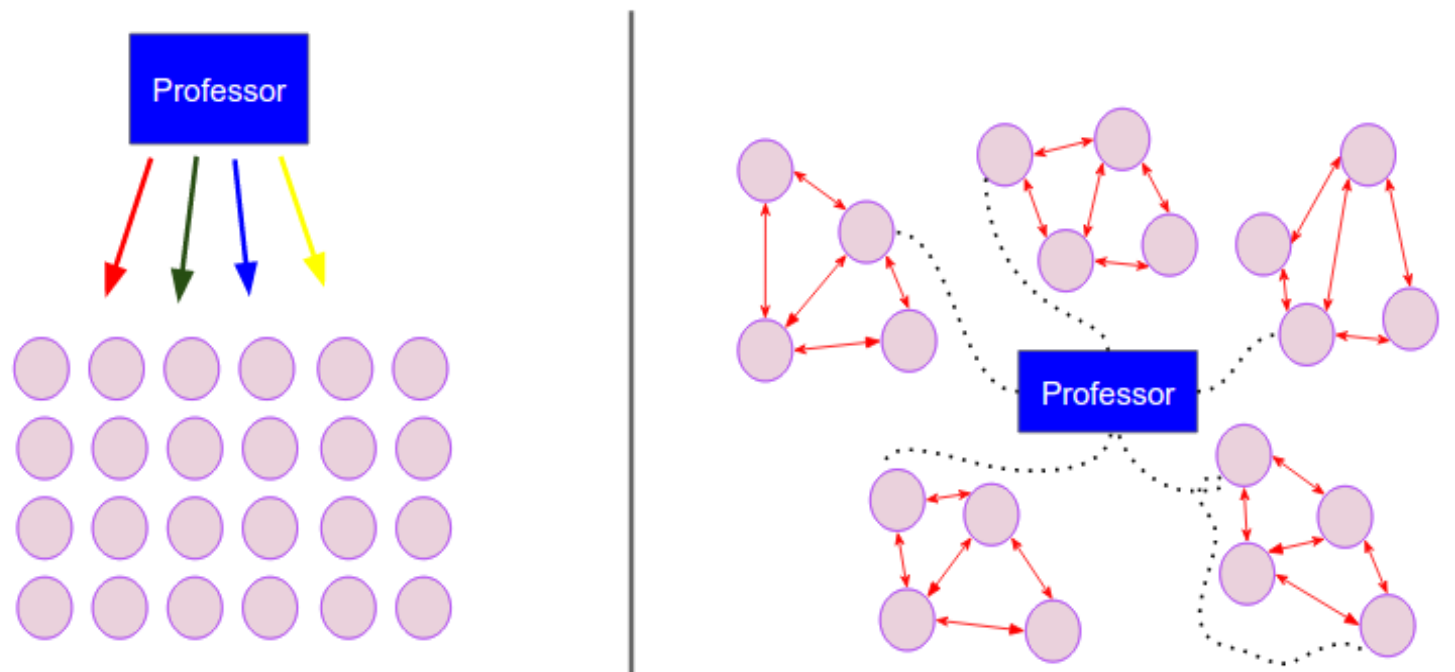

Figura 10 - Diagrama de comparação das metodologias tradicionais e ativas.

Fonte: Autora adaptado de

http://eventos.funadesp.org.br/xi encontro graduacao/docs/apresentacao/ives araujo.pdf

O incremento deste projeto está no uso das tecnologias para potencializar as conexões durante o processo de ensino/aprendizado, pois ao apresentar a possibilidade do uso de novas ferramentas e com a capacidade de conexão advinda das habilidades desta geração de jovens, o que percebemos é um aumento exponencial de conexões voltadas para o desenvolvimento de novas habilidades cognitivas. Este aumento se dá não somente na relação horizontal entre professor e estudantes, mas também como possibilidade de interação de outros agentes de aprendizagem. A figura 11 mostra como se desenham essas relações, mostrando a diferenças do uso de novas tecnologias utilizando-se métodos tradicionais e métodos ativos de ensino. 


\section{Métodos Tradicionais

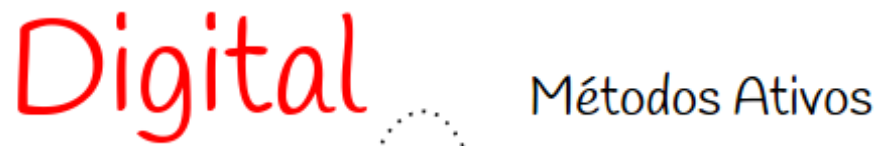

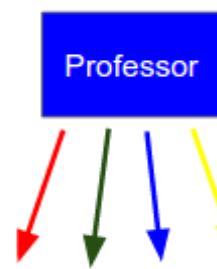
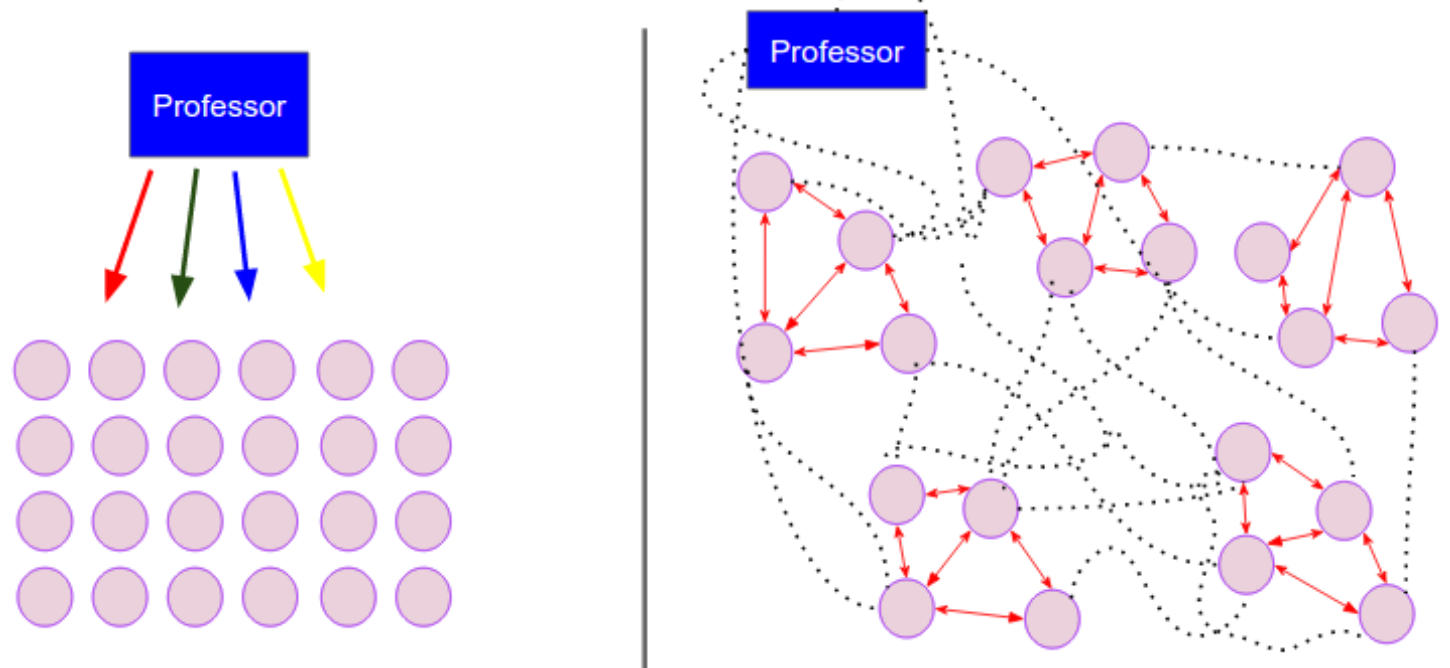

Figura 11 - Diagrama de comparação das metodologias tradicionais e ativas quando utilizadas com base na teoria do conectivismo. Fonte: Autora.

Ao compararmos as figuras 10 e 11 percebemos que a introdução de tecnologias sem a estruturação dialógica dos métodos ativos não provoca diferença nas conexões e interações quando utilizam-se métodos tradicionais. Portanto, esse diálogo proporcionado durante o desenvolvimento deste projeto, mediado pela tecnologia [Abegg e Bastos, 2012], mobiliza a quebra da concepção bancária da educação e rompe com a relação vertical, mostrando que o ser humano é um ser em construção constante e que não devem existir relações de dominação com relação aos saberes e ao conhecimento.

Ao utilizar uma rede social como ferramenta de comunicação com o jovem, o educador se aproxima da realidade dos estudantes, da sua linguagem, da sua forma de expressão, do contato com o mundo. Nesta dissertação vamos verificar que tal atitude potencializa a aprendizagem.

O que se pretende investigar, realmente, não são os homens, como se fossem peças anatômicas, mas 0 seu pensamento-linguagem referido à realidade, os níveis de sua percepção desta realidade, a sua visão do mundo, em que se encontram envolvidos seus "temas geradores. 
[...] nos parece que a constatação do tema gerador, como uma concretização, é algo a que chegamos através, não só da própria experiência existencial, mas também de uma reflexão crítica sobre as relações homens-mundo e homenshomens, implícitas nas primeiras. [Freire, 1974, p. 49]

Não estamos aqui a afirmar que houve nesse processo a busca e a investigação de um tema gerador, tendo em vista que o professor escolheu o tema do projeto, mas para compreender este caso vamos nos debruçar em sua concepção relatada a seguir.

Em 2013, durante uma aula de dispersão da luz por refração, percebemos que poderíamos explorar o tema de maneira mais dialógica com os estudantes. Pensou-se, naquela época, em fazer uso do Instagram como ferramenta de incentivo à busca por explicações para os fenômenos ópticos. Considerando então a relação horizontal do processo foi solicitado durante uma aula que os estudantes fizessem uma busca no Instagram pelos \#arcoíris e \#rainbow de forma a localizar imagens do arco-íris. A foto a seguir foi encontrada em uma rápida busca, agora, em junho 2016.

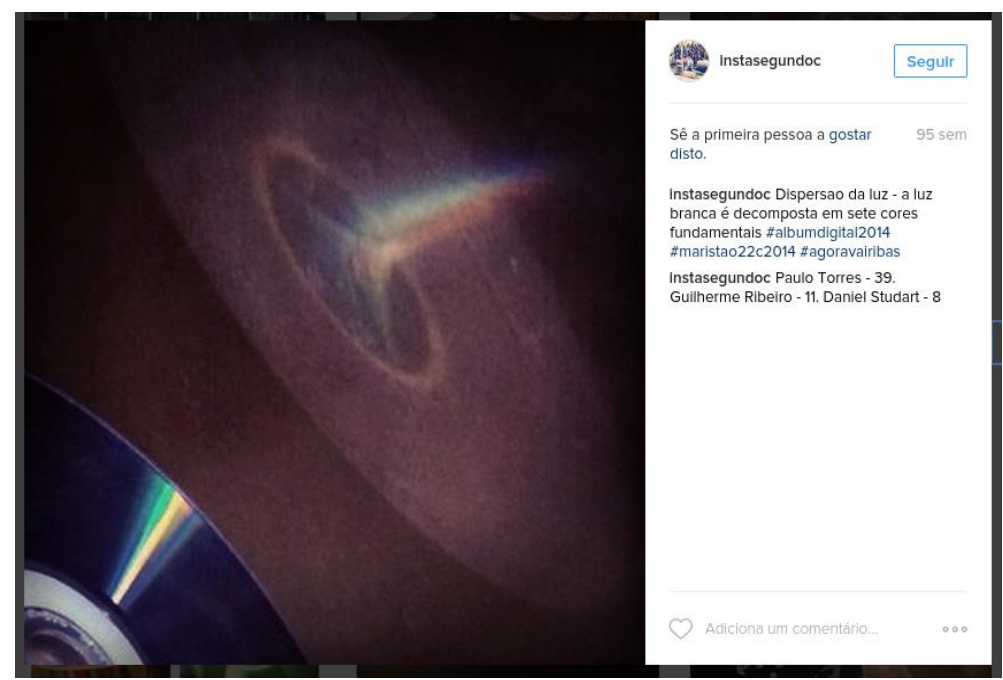

Figura 12 - Captura de tela de foto disponível no Instagram. Fonte:

https://www.instagram.com/p/rVzgingCDm/?tagged=albumdigital2014 Acesso em junho 2016 
Os alunos já estão familiarizados com as redes sociais. Mesmo que não queiram misturar educação com o lazer, eles já sabem utilizar essas ferramentas, por isso fica mais fácil explorar seus recursos. [Juliani et al, 2012, p. 02]

$\mathrm{Na}$ época os jovens encontraram, além das diversas fotos de arco-íris, imagens como a apresentada acima, no momento em que estas fotos foram encontradas e apresentadas para a turma, os jovens foram indagados a respeito do fenômeno: "será que ali realmente estava acontecendo o fenômeno da refração? " A turma inteira concordou, mas quando foram informados de que se tratava do fenômeno da dispersão da luz por redes de difração, houve um alvoroço e muitos se questionaram a respeito da validade das informações que encontramos na rede. A turma foi levada a discutir a importância do letramento científico e como nossa sociedade não se preocupa com esse letramento, a partir daí, foi sugerido pelos estudantes uma campanha que inundasse as redes sociais de explicações simples para fenômenos simples. Dessa aula nasceu o projeto: Fenômenos Ópticos.

Contudo, podemos perceber que apesar do tema do projeto não ter sido objeto de discussão com a turma, como prevê a metodologia freireana para investigação dos temas geradores como ponto de partida do processo de aprendizagem, o tema surgiu naturalmente e foi problematizado pelos próprios jovens em busca de aprimoramento do seu conhecimento e da preocupação com divulgação científica, pois ele é um esforço comum de consciência da realidade e de autoconsciência desta geração.

Considerando-se que há áreas do saber em que os professores pouco se utilizam da contextualização por considerarem "específicas demais", há a necessidade de proporcionar-Ihes estratégias diferenciadas que promovam a superação de tais dificuldades. [Costa e Pinheiro, 2013, p. 37] 
Dentro da investigação dos fenômenos que ocorrem em nosso cotidiano, como não se trata de um processo mecânico, é possível praticar a pedagogia freireana e auxiliar os sujeitos a descobrir, no encadeamento dos temas significativos, a interpenetração dos fenômenos que ocorrem na natureza. Quando discutimos sobre os fenômenos ópticos e os jovens passam a relatar suas percepções a respeito do assunto, passam a observar a beleza física do mundo que os cerca. A investigação quanto mais crítica, menos focalista, mostra todos os fatores que influenciam na problemática apresentada. Esta ação dialógica aparece no projeto com os seguintes elementos:

Colaboração

Organização

\section{União}

\section{Síntese científico-cultural}

Quadro 7 - Elementos da ação dialógica. Paulo Freire

É notório que todos os elementos apresentados acima são elementos de busca da libertação, a síntese científico-cultural é toda ação científica, na forma sistematizada e deliberada de ação que incide sobre a estrutura social. Tudo aquilo que criamos socialmente ou em grupo por meio do diálogo busca transformação alcançando um novo padrão cultural. Educação para Freire não é só um ato pedagógico e, sim, um projeto de engajamento para descoberta científica como vamos perceber nesta dissertação.

A principal característica que os ambientes digitais possuem e que transforma totalmente a educação, a meu ver, é a aprendizagem ativa, em que o estudante se coloca no centro da educação, passando de um recipiente passivo para um agente empoderado. Isso muda tudo! [Gabriel, 2016, p. 01]

Neste contexto, considerando a capacidade da geração $Z$ de efetuar novas conexões, percebemos que esta habilidade se torna uma competência fundamental na formação, pois a aprendizagem constrói-se, também, por meio destas interligações entre pessoas presentes nas redes sociais [Siemens, 2010]. 
Nesta proposta didática procuramos verificar se modificações na interação entre professor e estudantes permeada pelas tecnologias poderão conduzir a uma grande alteração no resultado obtido no final do processo ensino/aprendizagem. Estamos cientes da probabilidade do professor, como parte desta uma rede, poder influenciar o caminho a ser seguido pelos seus estudantes, mas consideramos que esta influência faz parte da teoria do conectivismo e, portanto, é de suma importância nos processos cognitivos. Apoiamo-nos em Garcia [2015, p. 26] que advoga:

Saber onde encontrar o saber, aumenta a
importância do fator social no processo de
ensino/aprendizagem, considerando, neste sentido,
social, para além de um conjunto de indivíduos,
aquilo que está entre os indivíduos. Assim o
conhecimento poderá ser adquirido através da
interação de uma rede formada por professor e
estudantes, e também por terceiros que venham a
constituir-se como parte desta rede.

Esta nova proposta não pretende usar o determinismo tecnológico, que considera as ferramentas tecnológicas como fatores únicos e determinantes daquilo que se entende como melhoria no processo ensino-aprendizagem. A ideia é compreender o papel que desempenham no redirecionamento da prática docente $\mathrm{e}$, das possibilidades e potencialidades que possuem para promover práticas mais dinâmicas de forma a ajudar educadores a lidar melhor com essa nova realidade. A nossa proposição é de que um novo desenho para uma unidade didática pode se tornar um campo frutífero para a realização de situações e estratégias de aprendizagem que tirem melhor proveito dos recursos que fazem parte do cotidiano dos estudantes, tal como os smartphones. Nesse novo espaço de aprendizagem pretende-se aumentar a interação, o protagonismo acadêmico e intensificar a relação horizontal entre professores e alunos. Passa a ser possível a troca de informações em que ambos podem comparar e discutir dados, descobertas e socializar dúvidas [Lacerda e Silva, 2015]. 


\subsection{Os fenômenos ópticos no PCN e no ENEM}

A proposta para o Ensino Médio, no que se relaciona às competências indicadas na Base Nacional Comum, correspondentes à área de Ciências da Natureza estão apresentadas em um documento conhecido como Parâmetros Curriculares Nacionais. Nesse documento, é possível encontrar as diretrizes para o ensino de Física e a sua leitura é matéria obrigatória nos cursos de licenciatura.

Convém ressaltar que o documento foi elaborado por uma equipe de professores e pesquisadores do ensino de Ciências e Matemática. Não houve em sua concepção a preocupação em se elaborar uma nova lista de conteúdos, mas sobretudo dar ao ensino de Física novas dimensões, ou seja, promover um conhecimento contextualizado e integrado à vida de cada jovem. Além disso, tem por propósito prover aos alunos condições para desenvolver uma visão de mundo atualizada, o que inclui uma compreensão mínima das técnicas e dos princípios científicos em que se baseiam. Desse documento, destacamos as seguintes competências e habilidades desenvolvidas nesta proposta didática.

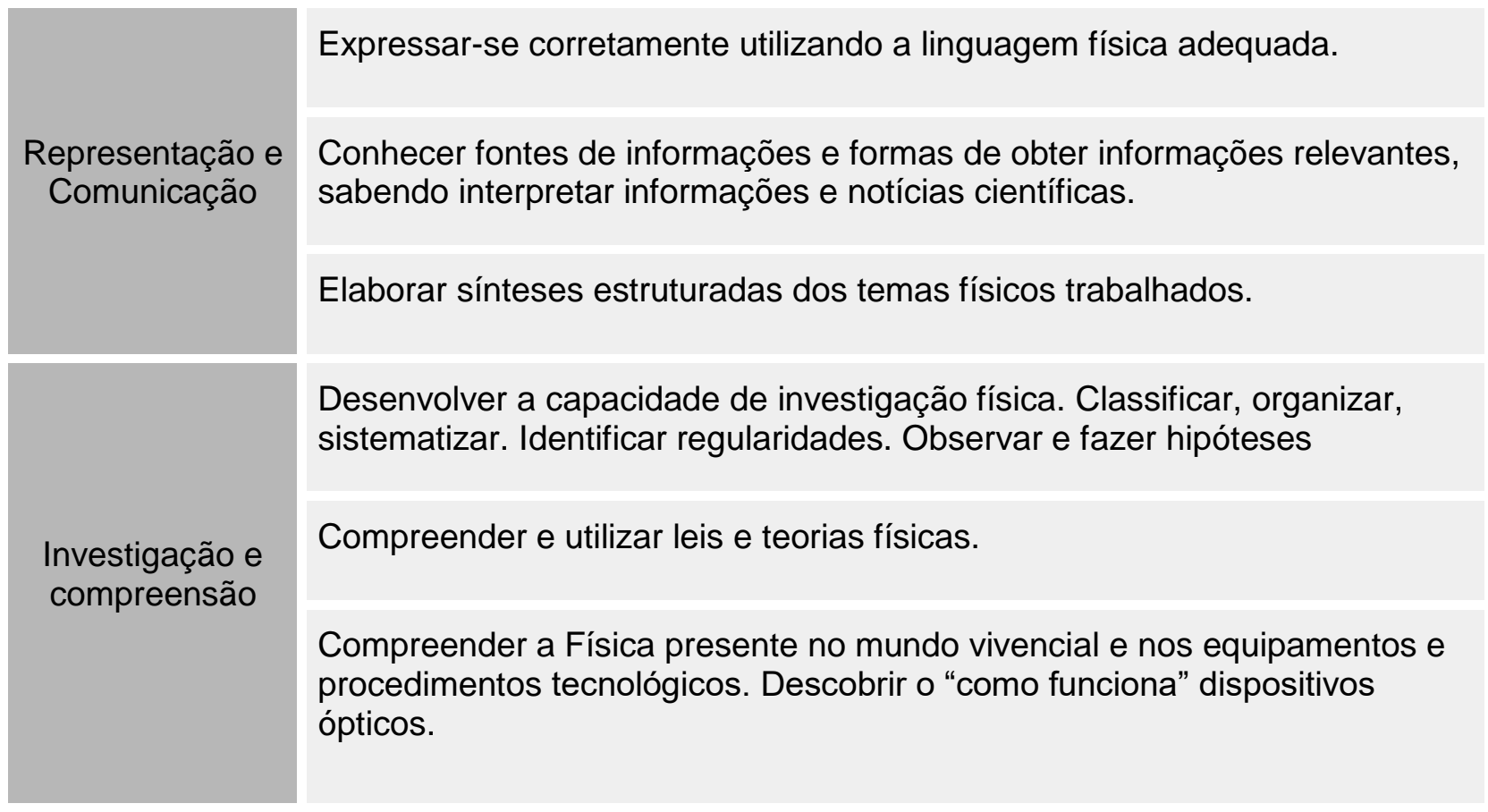


Contextualização sociocultural
Estabelecer relações entre o conhecimento físico e outras formas de expressão da cultura humana.

Reconhecer o papel da Física no sistema produtivo, compreendendo a evolução dos meios tecnológicos e sua relação dinâmica com a evolução do conhecimento científico.

Quadro 8 - Competências e habilidades apresentadas no PCN contemplados pela proposta didática. Fonte: Autora.

O documento ainda destaca que é comum o uso de aulas expositivas, como única técnica didática, ressaltando que esta é sempre cansativa e desinteressante, mas que por meio de novas estratégias podem ser adequadas a momentos de diálogo, do exercício da criatividade e do trabalho coletivo de elaboração do conhecimento. Em relação as aulas e livros, informa, contudo, que

[...]em nenhuma hipótese resumem a enorme diversidade de recursos didáticos, meios $\mathrm{e}$ estratégias que podem ser utilizados no ensino das Ciências e da Matemática. O uso dessa diversidade é de fundamental importância para o aprendizado porque tabelas, gráficos, desenhos, fotos, vídeos, câmeras, computadores e outros equipamentos não são só meios. Dominar seu manuseio é também um dos objetivos do próprio ensino das Ciências, Matemática e suas Tecnologias. Determinados aspectos exigem imagens e, mais vantajosamente, imagens dinâmicas; outros necessitam de cálculos ou de tabelas de gráfico; outros podem demandar expressões analíticas, sendo sempre vantajosa a redundância de meios para garantir confiabilidade de registro e/ou reforço no aprendizado. PCN, 1998, p. 53 - Grifo da autora

Observa-se que o documento elaborado em 1997 e publicado em 1998, já nos dava indícios de que projetos de Ciências da natureza, conforme o apresentado nesta dissertação, são recomendados como estratégias didáticas para o ensino de Física de forma a desenvolver conhecimentos mais associados às necessidades da vida contemporânea e à formação de uma cultura científica. [Albuquerque et al, 2015]. Além dos PCN, vamos ressaltar a presença do escopo 
deste projeto na Matriz de Referência de Ciências da Natureza e suas Tecnologias para o ENEM (Exame Nacional do Ensino Médio).

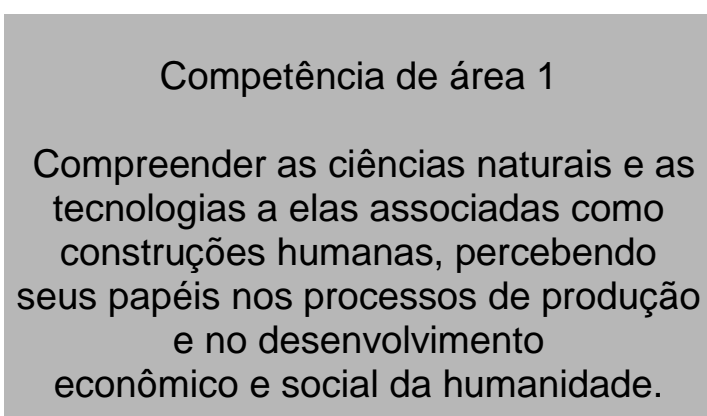

Competência de área 5

Entender métodos e procedimentos próprios das ciências naturais e aplicálos em diferentes contextos.

Competência de área 6

Apropriar-se de conhecimentos da física para, em situações-problema, interpretar, avaliar ou planejar intervenções científico-tecnológicas.
H1 - Reconhecer características ou propriedades de fenômenos ondulatórios ou oscilatórios, relacionando-os a seus usos em diferentes contextos.

H3 - Confrontar interpretações científicas com interpretações baseadas no senso comum, ao longo do tempo ou em diferentes culturas.

H17 - Relacionar informações apresentadas em diferentes formas de linguagem e representação usadas nas ciências físicas, químicas ou biológicas, como texto discursivo, gráficos, tabelas, relações matemáticas ou linguagem simbólica.

H18 - Relacionar propriedades físicas, químicas ou biológicas de produtos, sistemas ou procedimentos tecnológicos às finalidades a que se destinam.

H22 - Compreender fenômenos decorrentes da interação entre a radiação e a matéria em suas manifestações em processos naturais ou tecnológicos ou em suas implicações biológicas, sociais, econômicas ou ambientais.

Quadro 9 - Competências e Habilidades do ENEM contemplados pela proposta didática. Fonte: Autora

Contudo, podemos observar que os temas abordados no projeto estão em consonância com as demandas dos PCN e da matriz de referência do ENEM, validando o caminho escolhido, tendo em vista que ambos os documentos foram construídos, coletivamente, por um grande grupo de educadores. 


\section{METODOLOGIA}

Para elaborar o projeto que culminou no produto desta dissertação optamos pelo uso de ferramentas digitais e aplicamos estratégias didáticas alinhadas ao TPACK e o modelo SAMR que propõem o uso ferramentas como meio de aprendizagem permeadas por atividades presenciais. Esta metodologia foi adotada tendo em vista as recomendações dos PCN que vão ao encontro da teoria do conectivismo [SIEMENS, 2010] e os temas geradores de Paulo Freire.

Além disso, segundo artigo publicado, em 2014 no PNAS ${ }^{7}$, por Scott Freeman et al., o uso de metodologias ativas de ensino aumenta a performance dos estudantes em ciências, engenharia e matemática. Para testar a hipótese foram meta-analisados 225 estudos que relatavam dados sobre os resultados dos exames ou falhas na aprendizagem comparando o desempenho dos estudantes de graduação em ciências, tecnologia, engenharia e matemática sob metodologia tradicional em comparação às metodologias ativas. O estudo concluiu que há um aumento de $6 \%$ nas notas dos estudantes que participaram de aulas que utilizaram metodologias ativas de ensino.

Para verificar este incremento no desempenho, o público escolhido para o projeto fora formado por 320 estudantes do $2^{\circ}$ ano do Ensino Médio regular de uma escola privada de classe alta da cidade de Brasília, DF. A escolha desse público se deu para evitar intervenções alheias ao espaço da sala de aula como a falta de recursos tecnológicos. No entanto, ressaltamos que a mesma atividade foi aplicada em turmas da rede pública de ensino no ano seguinte apresentando a mesma eficácia, os resultados encontrados farão parte de um outro estudo após a publicação desta dissertação.

\footnotetext{
7 PNAS - Proceedings of the National Academy of Sciences of the United States of America. Disponível em <www.pnas.org> acesso em junho/2016.
} 
Não se trata de substituir os modelos convencionais de fazer educação. Trata-se de introduzir a cultura digital no ambiente educativo, com o intuito de promover a criatividade, a autonomia e a autoria dos envolvidos, na busca por estimular um processo de aprendizagem motivador e de fato permanente.

É preciso promover o debate e apontar possibilidades de uso, assim entende-se que é possível questionar a rigidez dos padrões e tornar a sala de aula mais flexível. Ganha o ensino de física, ganham professores e alunos e principalmente abrem-se novos horizontes para a Educação. [Lacerda e Silva, 2015, p. 177]

Nesta proposta as turmas foram divididas em grupos de, no mínimo, três e, no máximo, cinco estudantes. A proposta didática foi desenvolvida em 5 (cinco) etapas:

- 1aㅡ Etapa: Elaboração de sequência didática para orientação do projeto. Optouse por construir um site utilizando uma ferramenta gratuita chamada GOOGLE SITES, que se trata de um aplicativo que faz parte do pacote de Google Apps para educação, disponível gratuitamente para usuários de uma conta Google e permite o desenvolvimento de sites de maneira simples e acessível. Foram necessários cerca de $10 \mathrm{~h}$ de trabalho, na elaboração do site, considerando a expertise do usuário. O site é de domínio público e poderá ser utilizado como modelo para os educadores que desejarem fazer uso desta metodologia em suas aulas. Está disponível no link reduzido: bit.ly/fenomenosopticos. ${ }^{8} \mathrm{~A}$ figura 13, a seguir, apresenta a captura da tela inicial do site.

8 Para auxiliar o professor que desejar construir seu próprio site, foi elaborado pela autora uma vídeo-aula disponível no link: bit.ly/googlesitecomsamara 


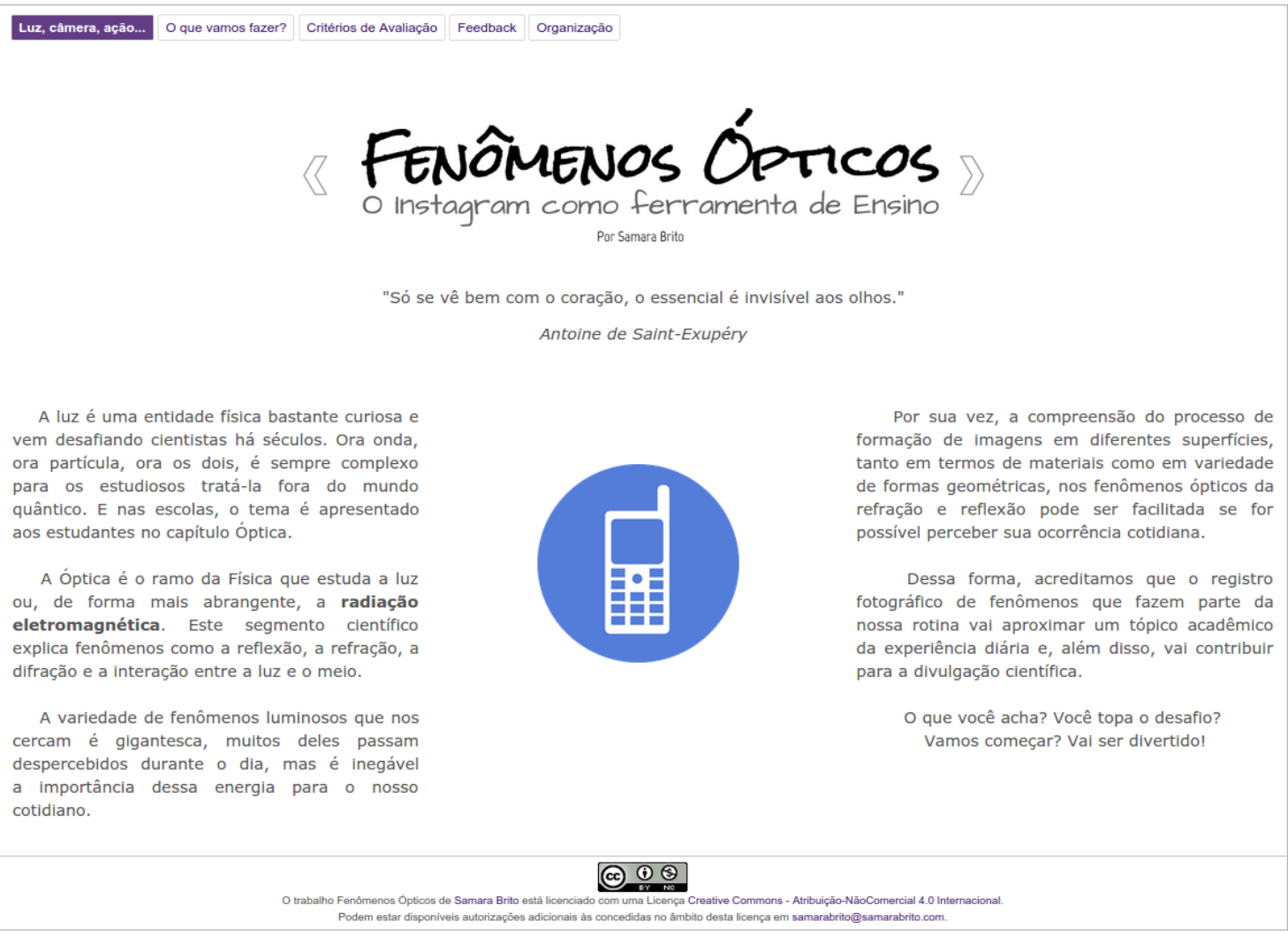

Figura 13 - Captura da tela inicial do site

- 2a Etapa: Apresentação do roteiro digital do projeto para os estudantes e aplicação do questionário de sondagem - formulário construído no Google Forms. $^{9}$ O tempo necessário para elaboração do formulário é de aproximadamente $3 \mathrm{~h}$ considerando a experiência do usuário. Optou-se por trabalhar com questões de múltipla escolha, com a possibilidade de aleatoriedade das respostas. Para esta atividade os estudantes estavam livres para consultar a internet e o seu material de apoio. Foram necessárias duas aulas para explicação do projeto e aplicação da sondagem conforme cronograma apresentado no site.

\footnotetext{
9 Ferramenta gratuita disponível no Google Apps para educação, gratuitamente para qualquer usuário de uma conta Google que pode ser utilizada para elaboração de questionários e atividades avaliativas. Para auxiliar o professor que desejar construir seu próprio formulário, foi elaborado pela autora uma vídeo-aula disponível no link: bit.ly/googleformscomsamara
} 


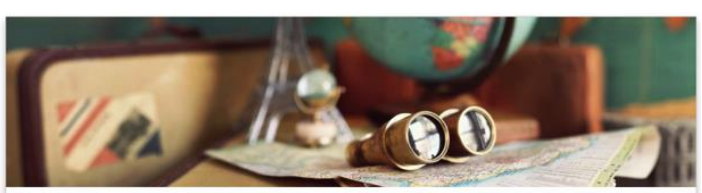

Atividade 1

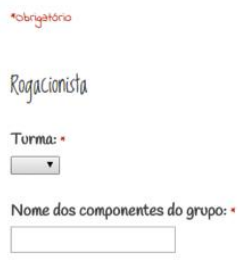

Nomero na Chamada *

-

Nómero na Chamada.

-

Nómero na Chamada.

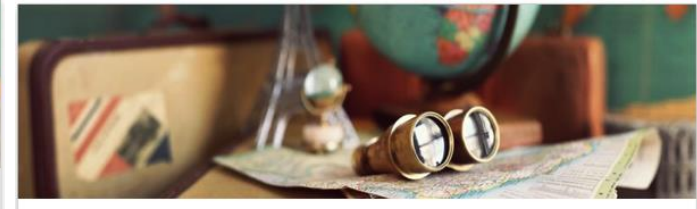

Atividade 1

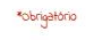

Pré - Teste

Fotogafár é una arte que se popularizou con as cellares e se intensificou com as redes sociais.

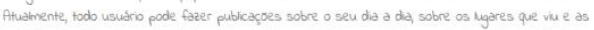

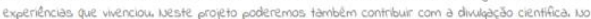
entanta, antes de relatar nossas expeniencia cotdiana com os diversos fenemenos opticos que nos

cercam, vamos testar nossos conhecimentos sobre este assunta

\section{Ban trobathd}

Samorare Brits

Figura 14 -Captura da tela do formulário aplicado em sala.

Para realização da sondagem os estudantes foram orientados em sala de que se tratava de uma atividade para levantar informações a respeito do seu domínio sobre o tema do projeto.

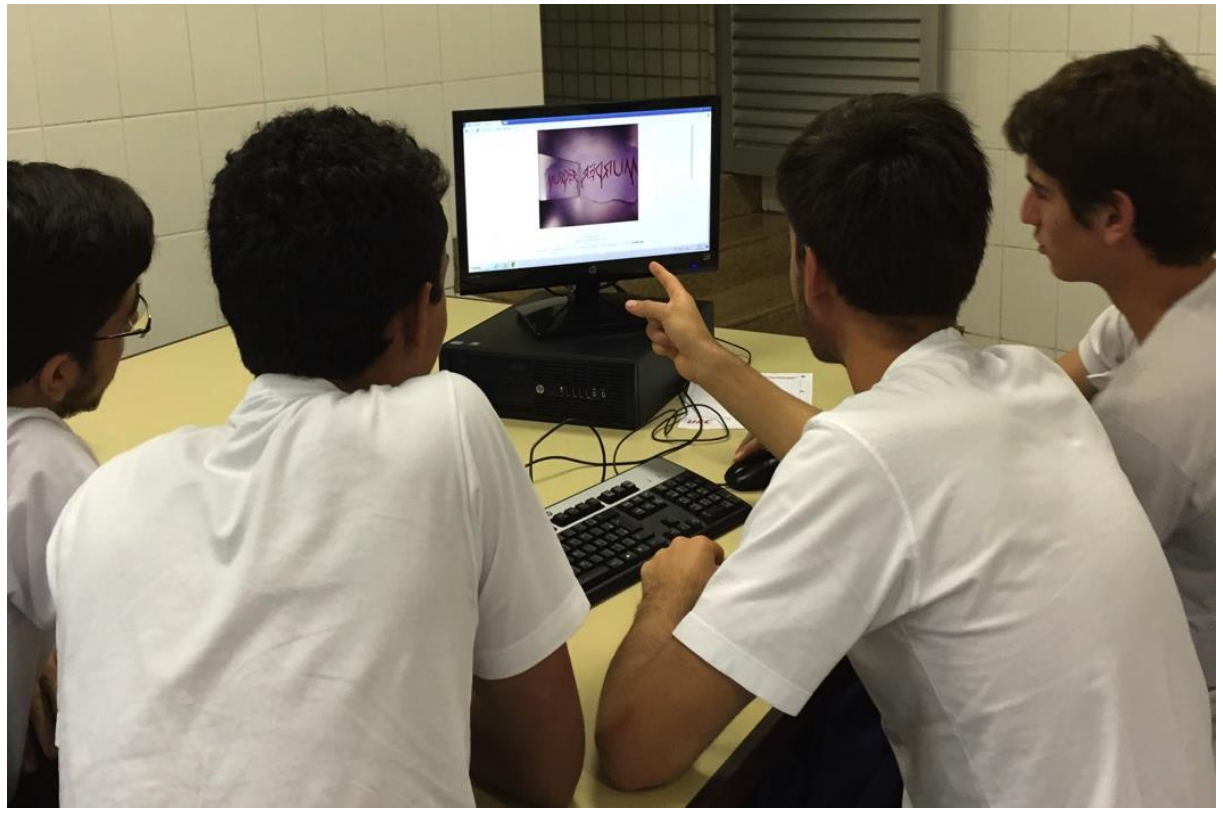

Foto 1 - Aplicação da atividade de sondagem. Fonte: Arquivo pessoal da autora. 


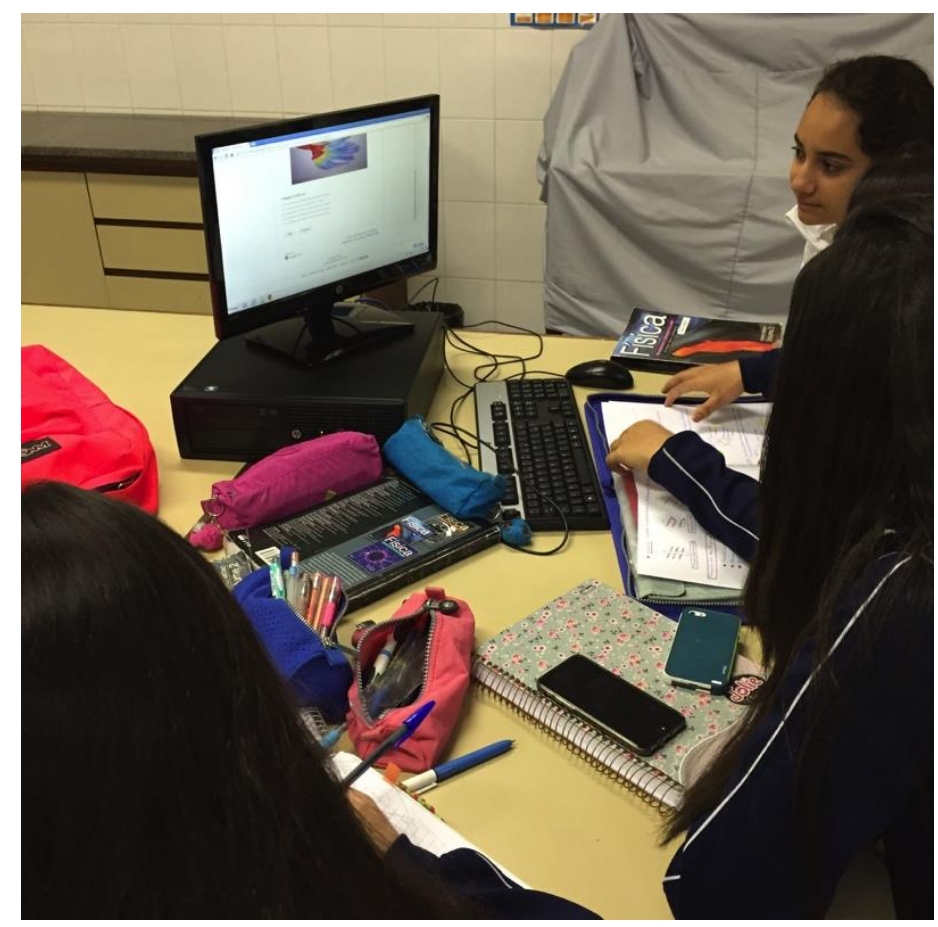

Foto 2 - Aplicação da atividade de sondagem. Fonte: Arquivo pessoal da autora

- 3a Etapa: Apresentação, do álbum digital que foi construído dentro do Instagram, utilizando-se as fotos autorais que os estudantes tiraram a respeito dos fenômenos ópticos solicitados no projeto, em sala de aula, para a turma e para a professora. É válido ressaltar que nesta proposta didática não foi permitido o uso de imagens já disponíveis na rede. Os grupos se organizaram para fazer fotos inéditas sobre os temas. Para apresentação das fotos de cada grupo optou-se pela ferramenta ICONOSQUARE ${ }^{10}$, por conta da sua capacidade de filtrar as fotos pela hashtag ${ }^{11}$. A utilização das hashtags é uma forma de mobilizar um grupo de indivíduos para determinada causa [Coelho, 2014]. Durante a apresentação, a professora fez a correção dos eventuais erros cometidos, discutiu com a turma cada uma das fotos e fenômenos

10 Website/ferramenta de monitoramento do app Instagram, que permite ao usuário verificar estatísticas de engajamento, realizar buscas por hashtags e usuários, e criar relatórios de performance. <iconosquare.com>

11 O termo hashtag representa a união de uma frase ou palavra-chave [tags] e o sinal gráfico de uma cerquilha [\#], com o objetivo de categorizar e organizar mensagens pertencentes a um determinado assunto ou tópico. Dicionário Oxford. Disponível em: $<$ www.oxforddictionaries.com/definition/english/hashtag> 
apresentados e avaliou o projeto por meio de um formulário construído no Google Forms. No entanto, atualmente, com a atualização das ferramentas pode-se utilizar para apresentação o site instagram.com. Foram necessárias duas aulas para essa atividade.

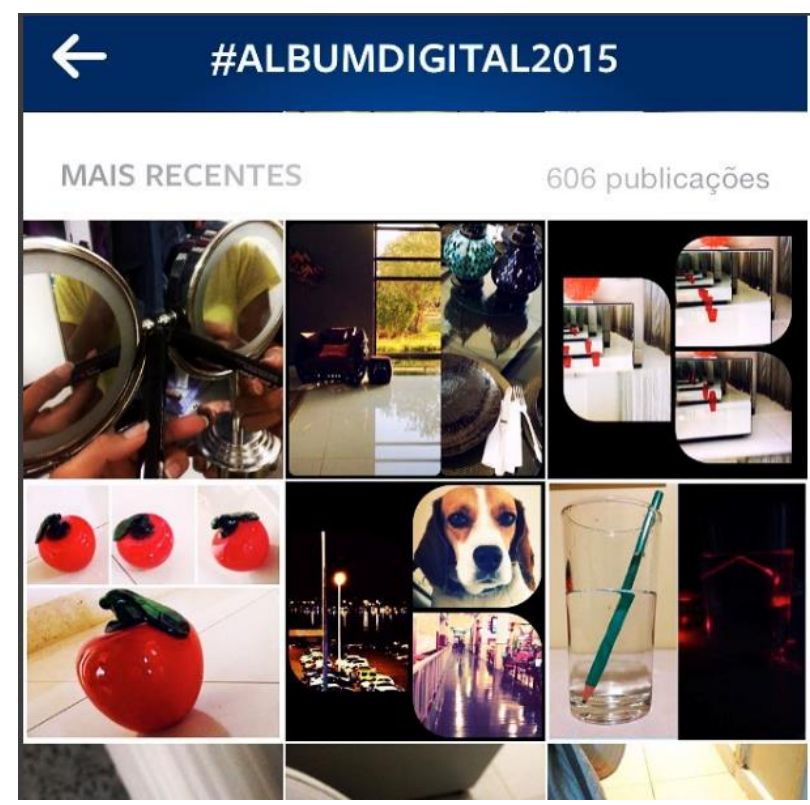

Figura 15 - Captura de tela do Instagram em pesquisa sob a hashtag: \#albumdigital2015 apenas para ilustrar como é possível localizar uma imagem.

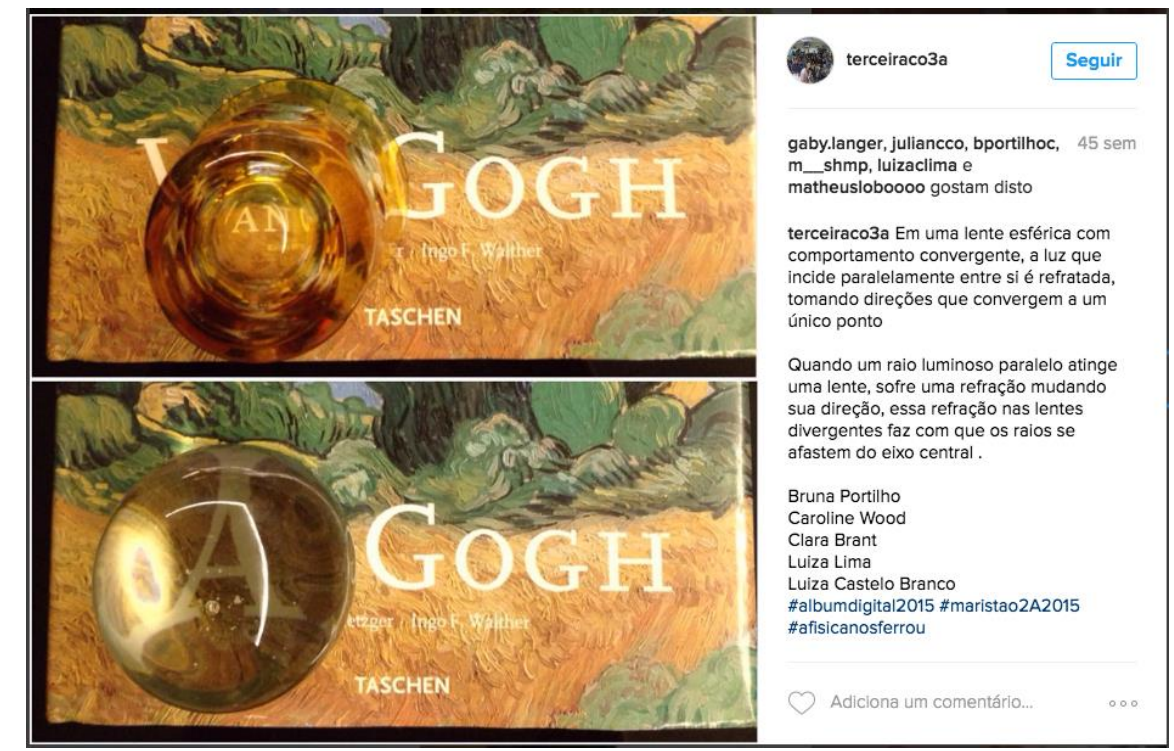

Figura 16 - Captura de tela do Instagram de uma das fotos apresentadas durante 0 projeto. 
- 4a Etapa: realização de uma atividade de pós-teste e uma atividade de feedback por parte dos estudantes, mais uma vez, via Google Forms, a fim de avaliar, sob o ponto de vista do jovem, sua percepção acerca do projeto. Nessa aula foram apresentadas as notas de cada grupo.

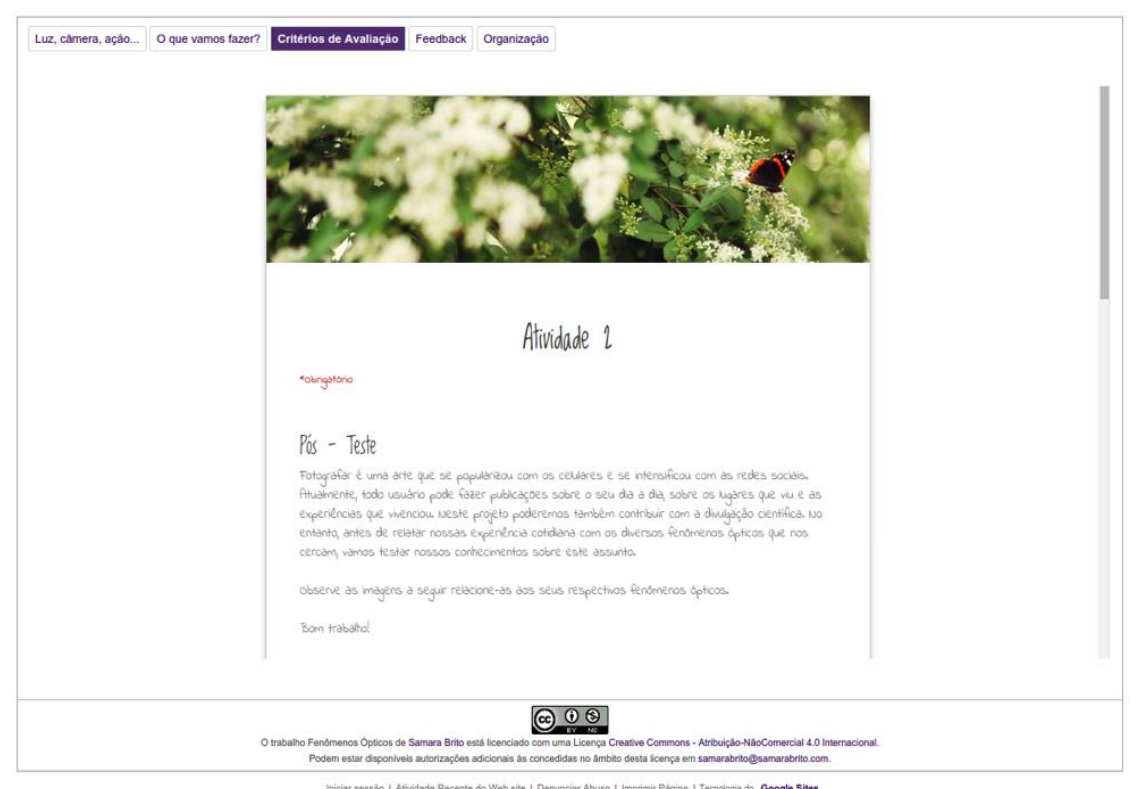

Figura 17 - Aplicação do Pós-teste. Fonte: Captura de tela do site do projeto

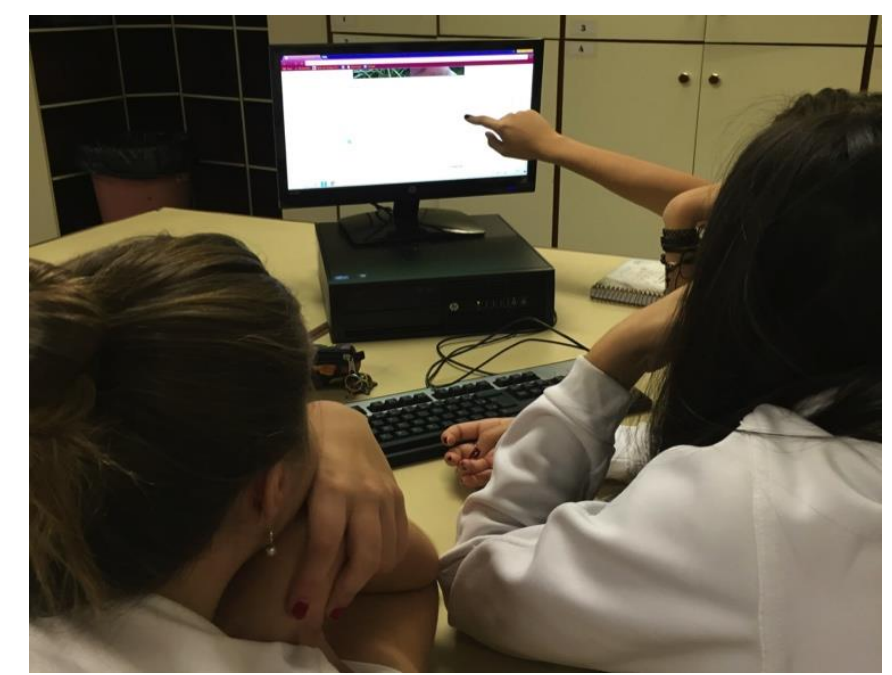

Foto 3 - Aplicação do Feedback. Fonte: Arquivo pessoal da autora. 


\subsection{Produto: Site sobre o projeto}

O produto desta dissertação é um modelo de site para uso de novas metodologias na sala de aula. O site foi construído utilizando o recurso Google Sites conforme mencionado anteriormente e possui a estrutura apresentada a seguir.

\section{Mapa do Site - Fenômenos Ópticos}

Luz, câmera, ação - Texto motivador de introdução ao conteúdo.

Objetivos - Apresentação dos objetivos do projeto

O que vamos fazer?

Sequência de atividades a serem realizadas durante o projeto.

Critérios de Avaliação Apresentação dos critérios de correção do projeto.
Motivação - Texto motivador a respeito do Ano Internacional da Luz

Temas - Lista dos temas a serem abordados no projeto.

Desafios - Lista de desafios a serem concluído para realização do projeto.

Cronograma - Cronograma das atividades a serem desenvolvidas ao longo do projeto e data de apresentação.

\section{Sondagem}

Atividade de sondagem para levantar os conhecimentos dos estudantes.

\section{Pós-Teste}

Atividade para verificação de aprendizagem aplicada após a apresentação do projeto.

Feedback - Formulário de pesquisa a respeito da percepção dos estudantes sobre o projeto

Organização - Apresentação dos educadores que auxiliaram na construção do site.

Mensagem para educadores - Mensagem para os professores que desejarem utilizar o modelo adotado nesta proposta didática.
Vídeo Aulas para elaboração de Formulários

Vídeo Aulas para construção de um Site

Avaliação - Formulário com a rubrica de avaliação do projeto.

Fotos de projetos anteriores.

Quadro 10 - Estrutura do Site do Projeto. Fonte: Autora 
Nas imagens a seguir, estão apresentadas as páginas construídas para o site conforme esquema do quadro 10.

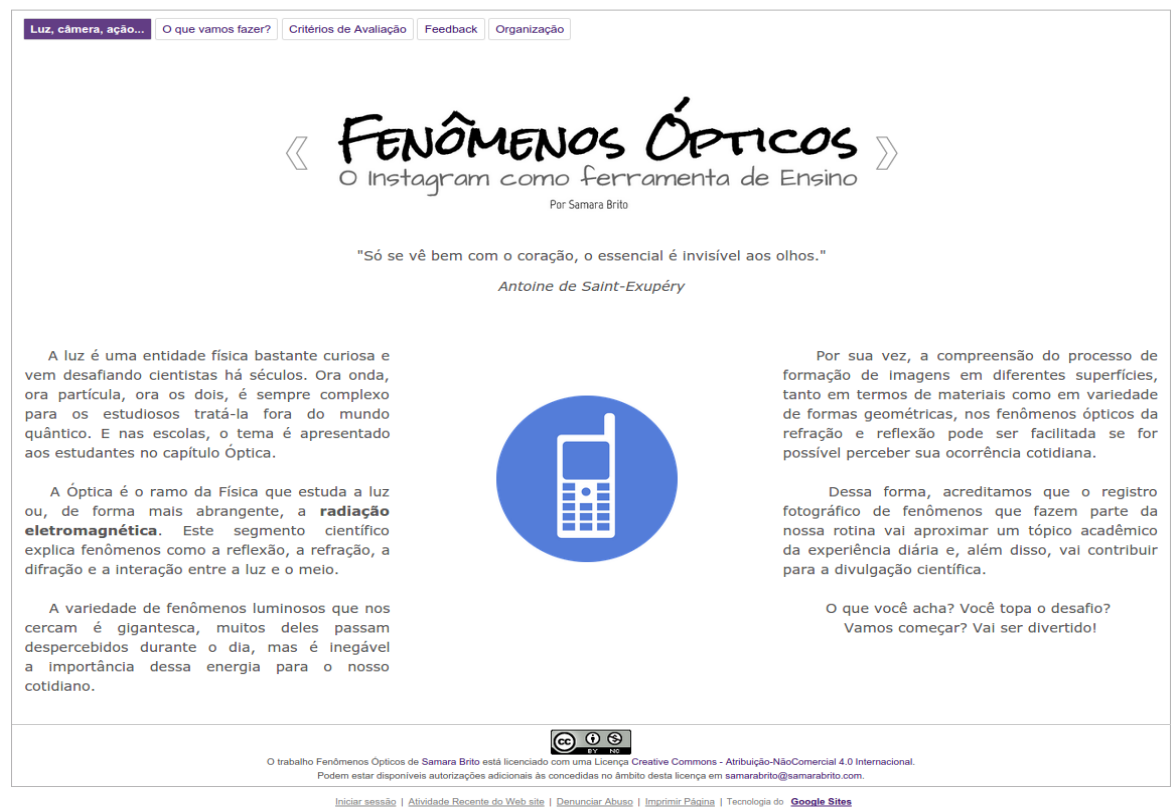

Figura 18 - Captura da tela da página inicial do site. ${ }^{12}$

Na tela inicial do site - Luz, câmera, ação... foi feita uma apresentação da importância do estudo da luz e um convite aos estudantes para fazer parte de um desafio. A intenção é dar início ao diálogo com os estudantes.

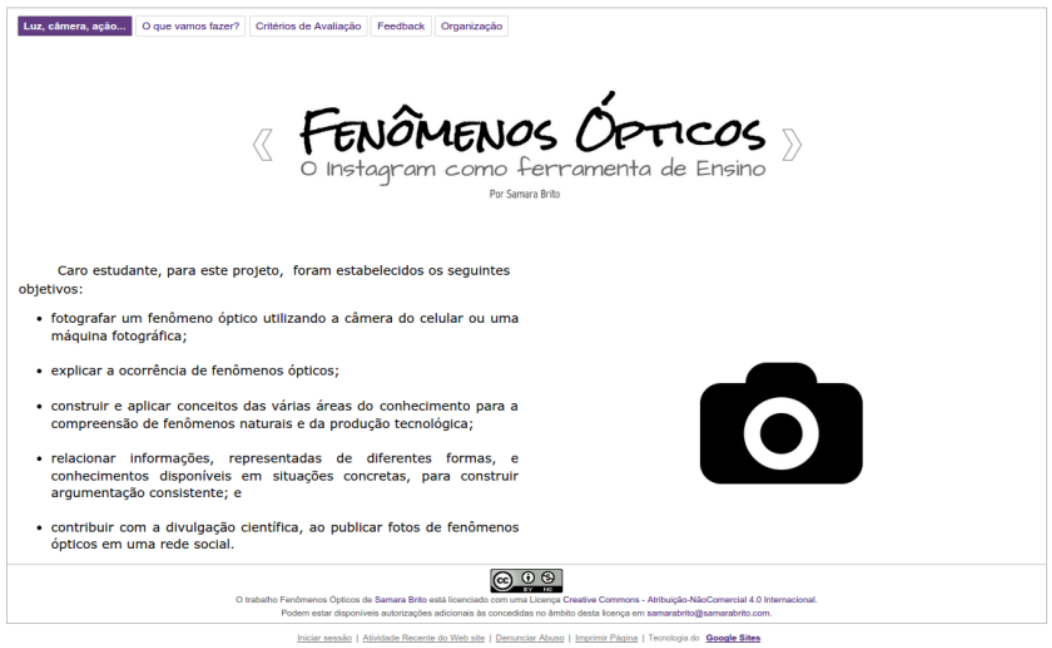

Figura 19 - Captura da tela dos objetivos do projeto.

${ }^{12}$ Disponível no link: https://sites.google.com/a/samarabrito.com/fenomenos-opticos/home 
$\mathrm{Na}$ aba intitulada Objetivos, foram apresentados os objetivos pedagógicos do projeto. Desta forma toda vez que estivessem em dúvida sobre aonde deveriam chegar com a sua pesquisa os estudantes poderiam acessar as informações diretamente no site.

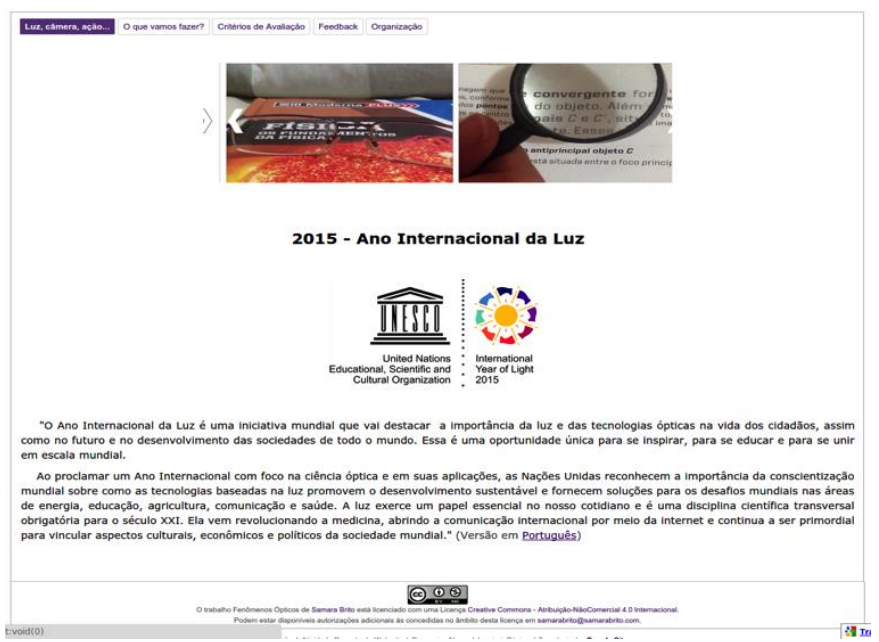

Figura 20 - Captura da tela da motivação para o projeto.

Nessa aba intitulada Motivação, foi feita a apresentação do ano internacional da luz, uma feliz coincidência em relação ao tema do projeto que foi introduzida de forma a ampliar os horizontes dos estudantes sobre o estudo da óptica.

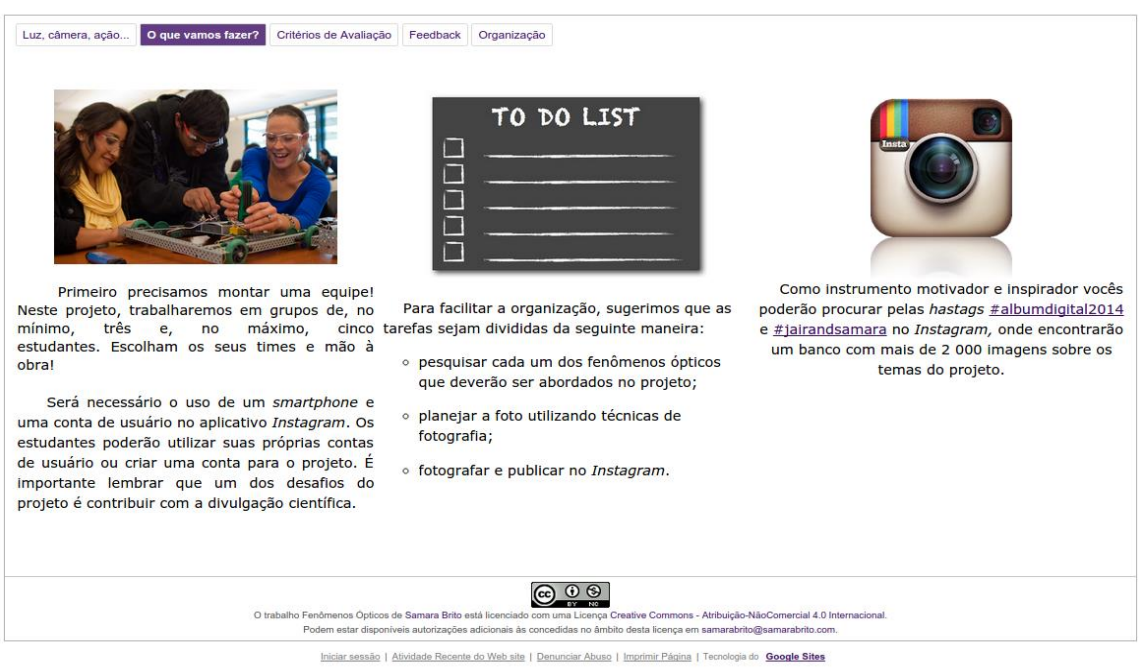

Figura 21 - Captura da tela de apresentação do projeto. 
$\mathrm{Na}$ aba, $\mathrm{O}$ que vamos fazer?, foi apresentada uma sequência de tarefas como forma de auxílio aos estudantes na organização das suas atividades para o projeto.

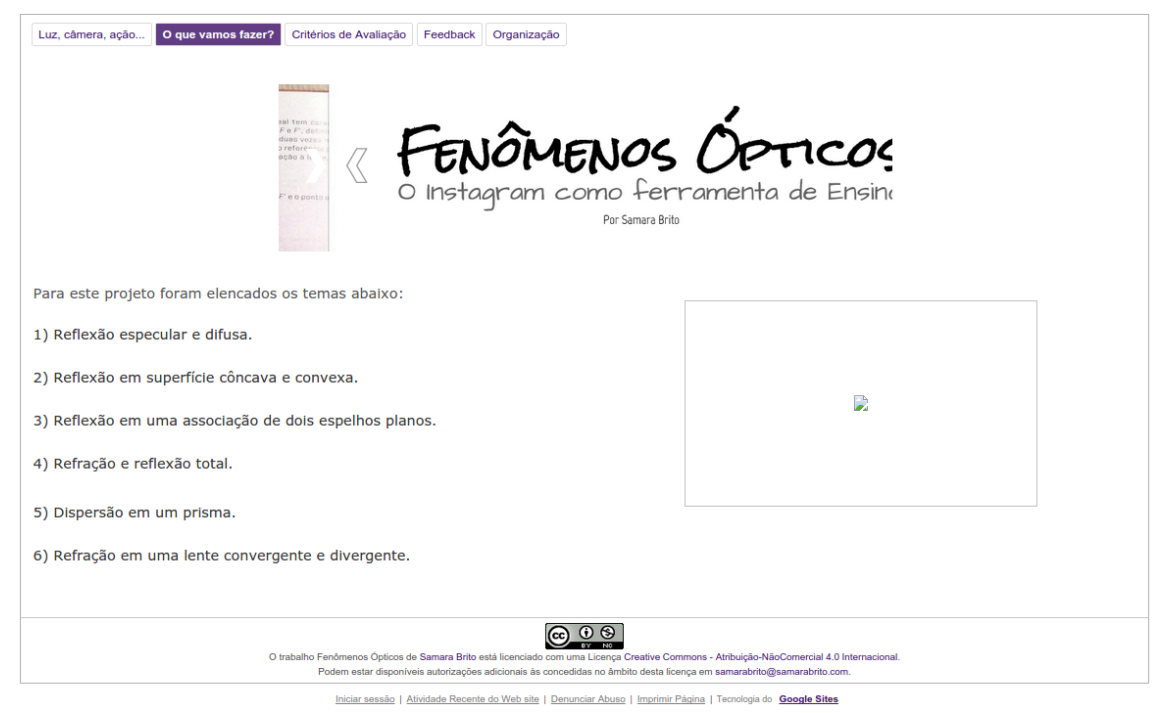

Figura 22 - Captura da tela que apresenta os temas do projeto.

Nesta aba Temas, colocamos à disposição dos estudantes os temas de cada foto a ser desenvolvida no projeto.

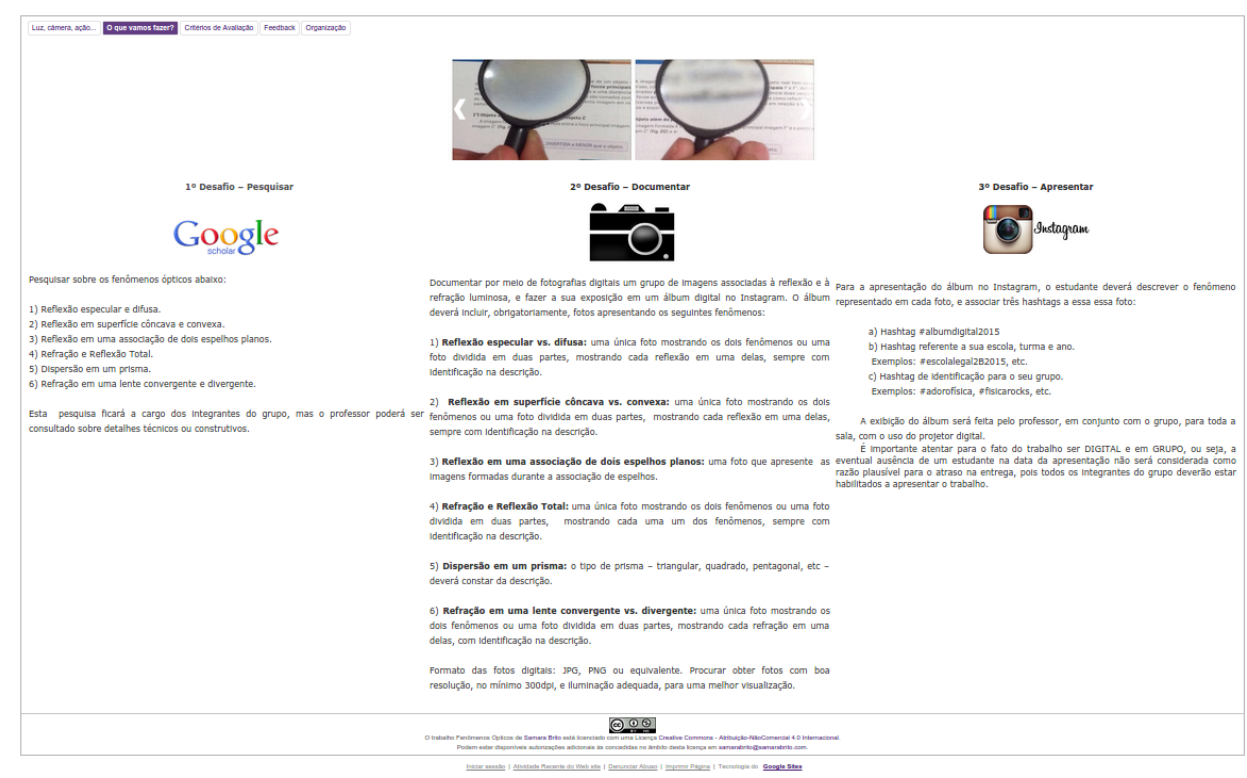

Figura 23 - Captura da tela com os desafios que os estudantes terão que realizar para construir o seu projeto. 
Como forma de auxiliar os estudantes nas atividades que deveriam desenvolver, apresentamos na aba Desafios, uma lista de atividades que deveriam ser realizadas ao longo do projeto até a construção e publicação das fotos.

O primeiro desafio consistia em fazer uma pesquisa na rede mundial de computadores a respeito dos temas do projeto. O segundo desafio estava associado a documentação por meio de fotos dos fenômenos pesquisados, além de instruções detalhadas sobre como deveriam ser apresentadas cada uma das fotos. O terceiro desafio era a postagem da foto no Instagram de acordo com as instruções do projeto além de informações a respeito da apresentação a ser realizada em sala posteriormente.

Para permitir uma melhor organização das atividades a aba seguinte apresenta um cronograma do projeto.

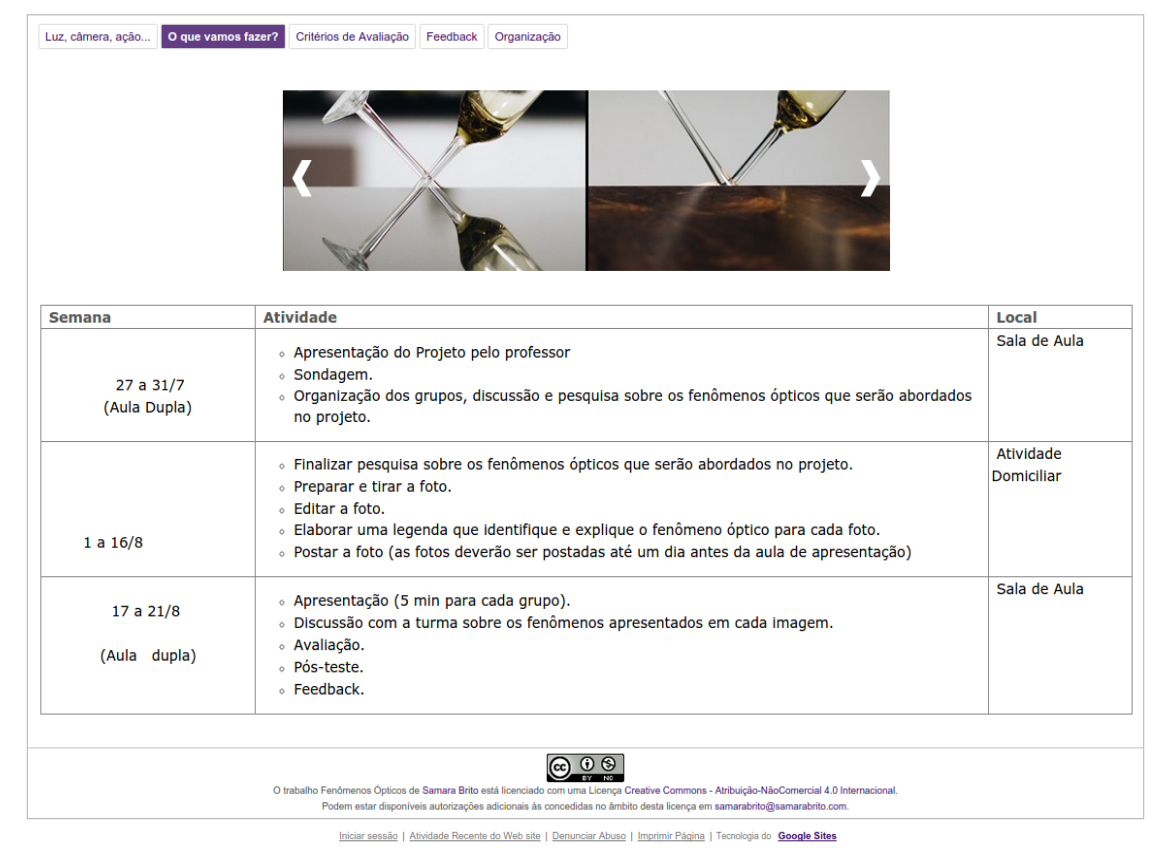

Figura 24 - Captura da tela do cronograma do projeto.

Para facilitar a organização dos grupos foi apresentado um cronograma de atividades a serem desenvolvidas até o dia da entrega do projeto. 


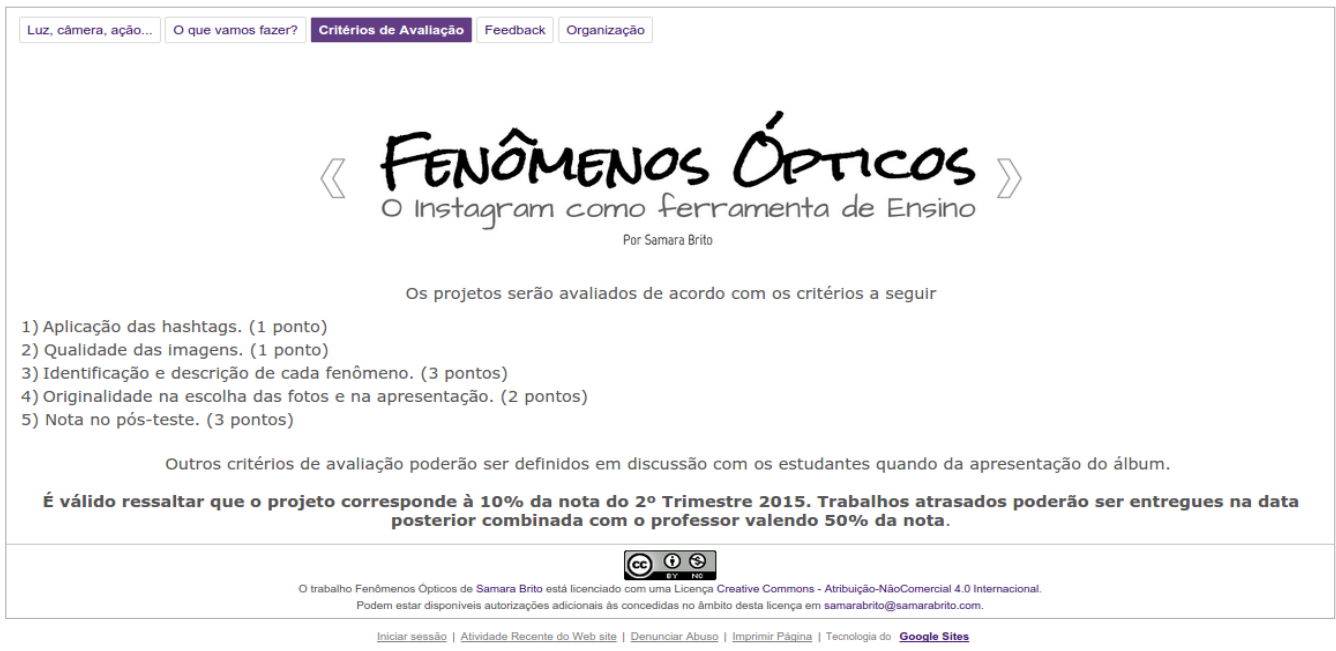

Figura 25 - Captura da tela dos critérios de avaliação.

Para garantir um processo transparente de avaliação foi apresentado aos estudantes os critérios de correção e aberta discussão para definição de outros critérios caso desejassem. Nenhuma turma apresentou novos critérios e todos concordaram com os critérios estabelecidos. Na subpágina seguinte estava disponível o formulário de sondagem.

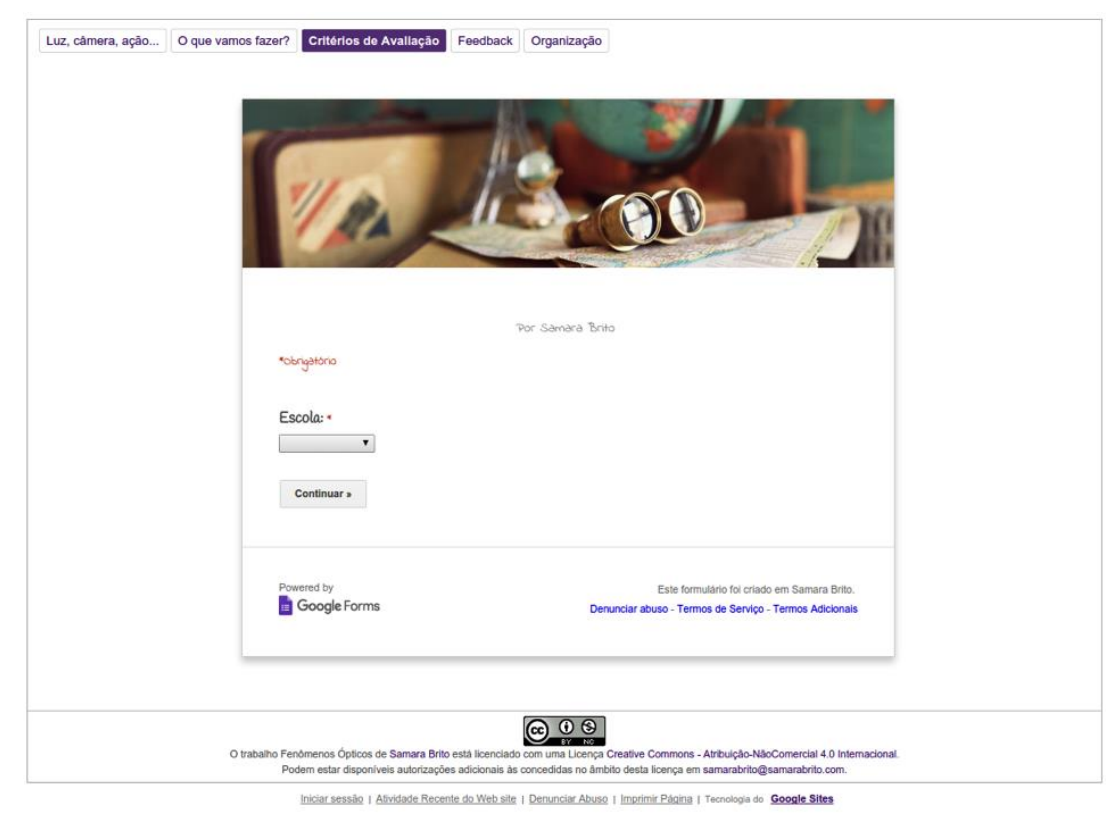

Figura 26 - Captura da tela da sondagem. 
Dessa forma, logo após a apresentação do projeto, os estudantes puderam realizá-la. A aba seguinte só foi disponibilizada depois da apresentação do projeto em sala de aula, para evitar que os estudantes a consultassem antes do estudo realizado.

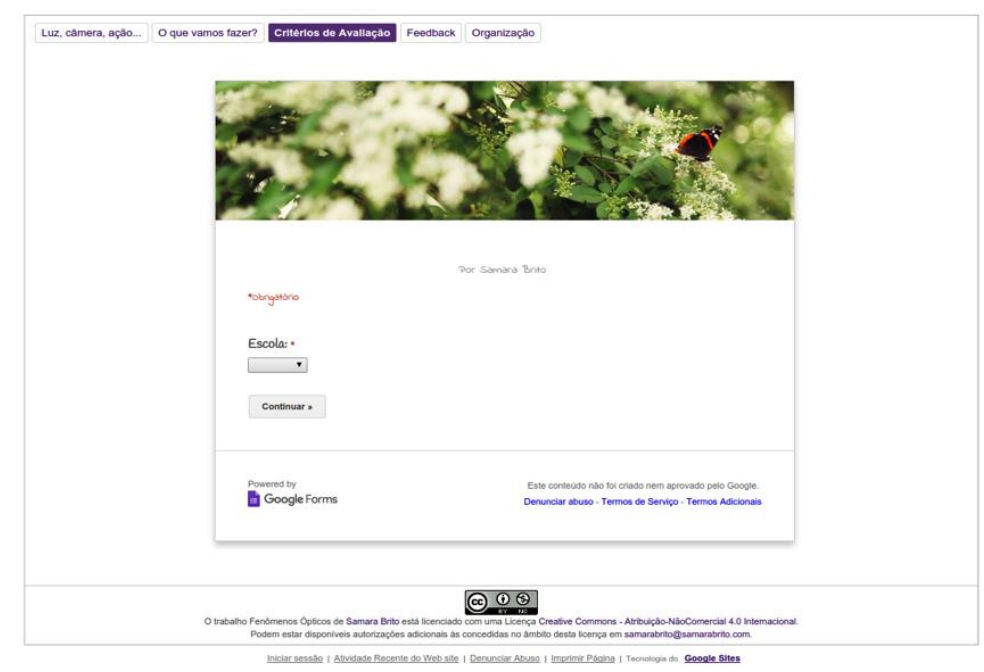

Figura 27 - Captura da tela do Pós-Teste.

Também após a apresentação do projeto foi adicionado na página seguinte o formulário de Feedback, que tinha por objetivo identificar a percepção dos estudantes a respeito do projeto e da sua forma de apresentação.

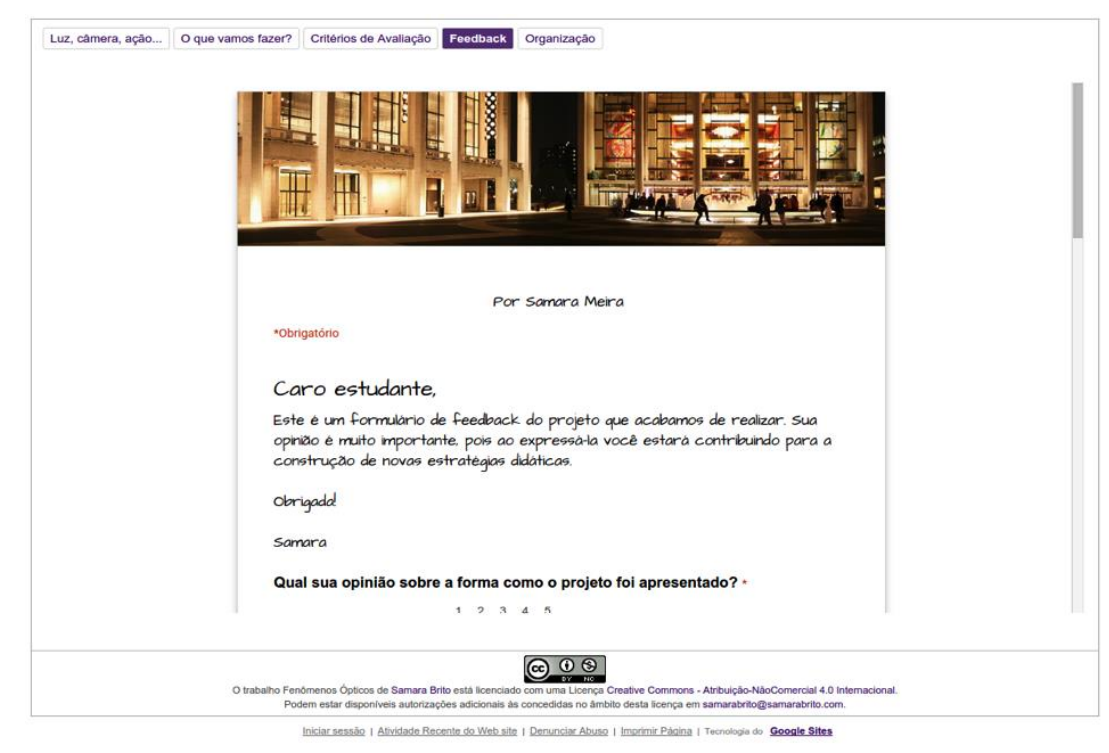

Figura 28 - Captura da tela do Formulário de Feedback. 
$\mathrm{Na}$ aba seguinte foi apresentada uma pequena bibliografia dos organizadores do projeto. Convém ressaltar que os estudantes ficaram muito empolgados em saber que havia mais de um educador envolvido na elaboração daquelas atividades.
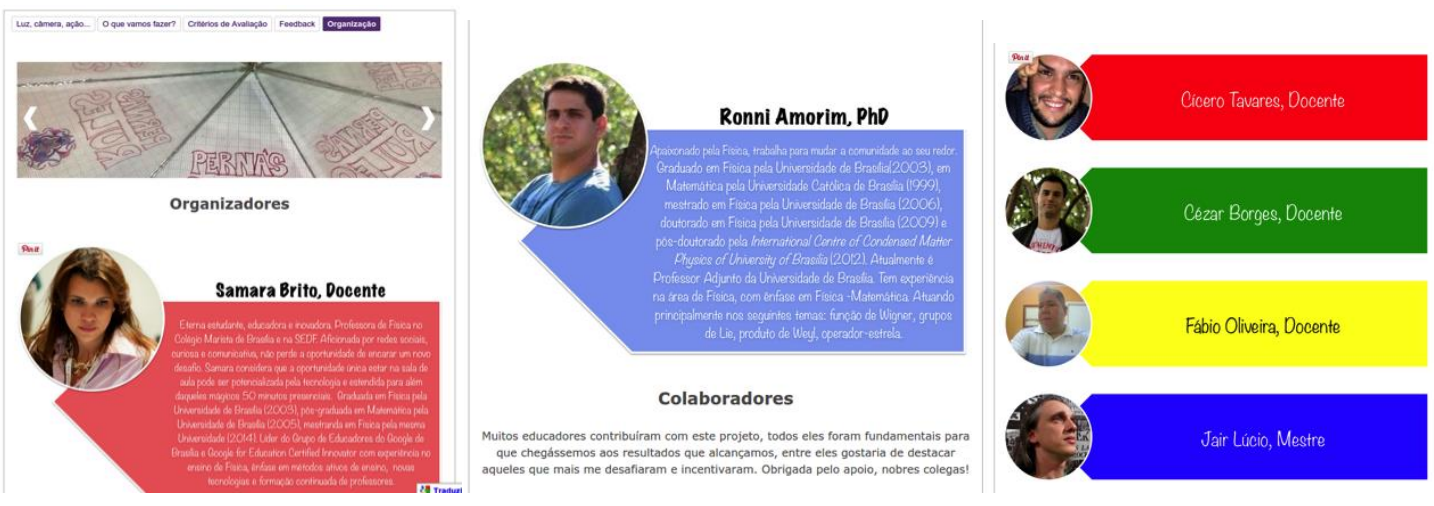

Figura 29 - Captura da tela da equipe organizadora do projeto.

$\mathrm{Na}$ última página do site, com intuito de incentivar mais educadores a adotar estratégias como as utilizadas nesta proposta didática, optamos por enviar uma mensagem e categorizar o material utilizado e vídeo-aulas com instruções para construção do próprio site, além de abrir um canal de comunicação com a comunidade docente.

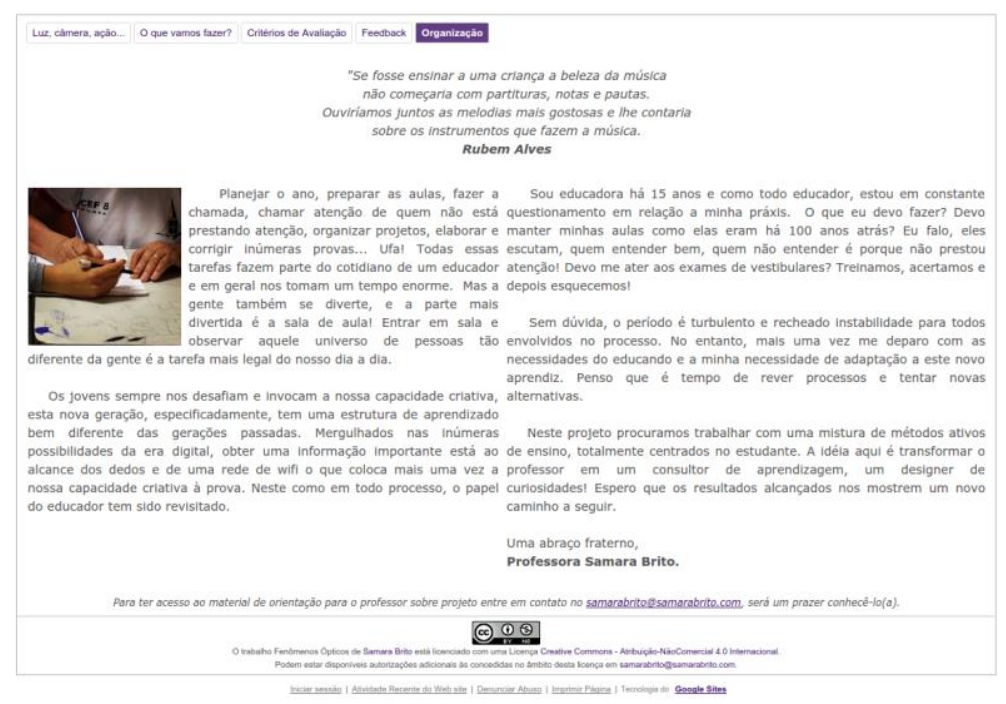

Figura 30 - Captura da tela da mensagem para os professores. 
Como subpágina da mensagem para os educadores adicionamos 0 formulário utilizado para fazer a avaliação do projeto.

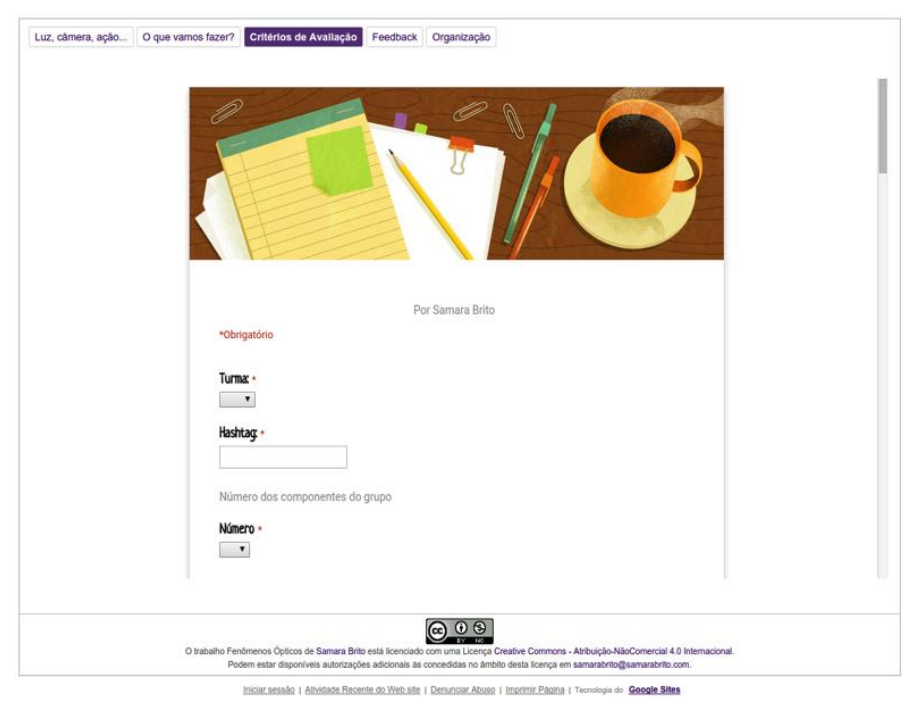

Figura 31 - Captura da tela da do formulário utilizado para avaliar as fotos postadas pelos alunos.

Para auxiliar educadores que desejarem fazer uso das ferramentas apresentadas nesta proposta didática, adicionamos uma subpágina com vídeoaulas sobre o Google Sites, Google Forms e Flubaroo. 


\section{ANÁLISE DE DADOS}

Para esta dissertação serão abordadas duas frentes para análise dos dados, uma quantitativa e outra qualitativa. Para fazer as duas análises e verificar a ocorrência ou não de aprendizagem foram elaboradas atividades de sondagem, pós-teste e feedback. A avaliação quantitativa está pautada na rubrica criada para avaliação do projeto e nos resultados dos estudantes na atividade de sondagem e no pós-teste. A avaliação qualitativa está pautada na percepção desta educadora durante a aplicação do projeto e no feedback dos estudantes a respeito da abordagem utilizada.

\subsection{Sondagem}

A atividade de sondagem foi construída utilizando-se a ferramenta Google Forms $^{13}$, com intuito de detectar o nível de conhecimento que os estudantes apresentavam sobre fenômenos ópticos cotidianos. Para isso foram utilizadas fotos do projeto aplicado no ano de 2014 , ou seja, fotos com a percepção de alunos da mesma faixa etária. A atividade foi planejada para ser respondida em grupos de, no mínimo 3 e no máximo 5 pessoas, era necessário identificar-se por meio do e-mail pessoal, além de identificar a instituição de ensino a qual pertenciam. Para aplicação da sondagem os estudantes foram orientados a pesquisar na internet sobre o tema e consultar o material didático, na época, o livro Física 2 - Termologia - Óptica - Ondulatória. Bonjorno, Clinton e Luís. $1^{\text {a }}$ Edição. Editora FTD.

Durante a aplicação da atividade, podemos notar que em geral os estudantes procuram primeiramente por respostas diretamente pelos sites de busca disponíveis na internet, no entanto, esta atividade foi concebida de forma totalmente personalizada e inovadora, sendo difícil encontrar uma resposta pronta nas ferramentas de busca. Acreditamos que ao se preparar uma atividade dessa

\footnotetext{
${ }^{13}$ O formulário completo está disponível no link: https://sites.google.com/a/samarabrito.com/fenomenosopticos/sondagem
} 
natureza estamos mostrando para o jovem que nem todas as respostas estão ao alcance dos dedos e que por vezes se faz necessária uma investigação para construção do conhecimento.

Numa primeira análise, parece que será fácil encontrar um gabarito pela rede, mas ao se deparar com a dificuldade de encontrar um resultado os estudantes passam a analisar o livro didático em busca de questões semelhantes, mais uma vez se encontraram com desafio difícil de cumprir, pois o livro também não possuía uma explicação direta para as questões. Por fim o que percebemos é que, os estudantes abandonam a procura por respostas fáceis e passam a discutir entre si as possíveis soluções para o problema apresentado. Também observamos que, superada esta etapa, os estudantes passam a fazer uma pesquisa mais direcionada na internet procurando apenas termos desconhecidos e procurando fazer ligações com a sua experiência cotidiana.

Acreditamos que esta etapa permitiu o desenvolvimento da inteligência coletiva e colaborativa, conforme defende Siemens [2010], para o processo de aprendizagem, o que torna os jovens protagonistas da sua aprendizagem e demonstra a importância do conhecimento científico para compreensão dos fenômenos que ocorrem na natureza. Nas imagens a seguir, apresentamos a pergunta utilizada na sondagem seguida da análise qualitativa e quantitativa da sua resposta.

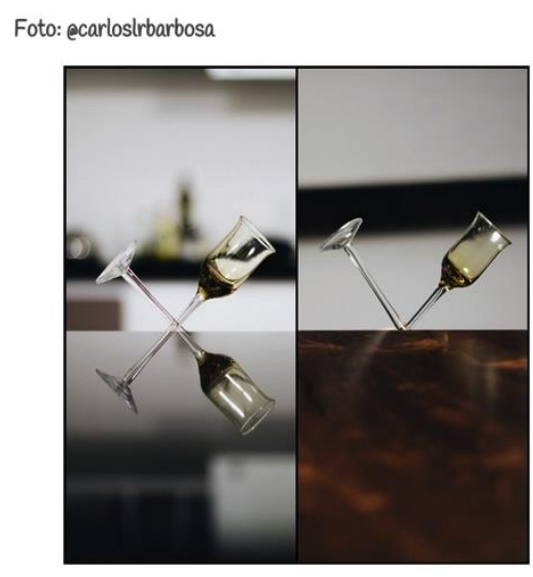

A imagem 1 refere-se *

ao fenômeno da reflexáo difusa nos dois casos.

ao fenômeno da refraçăo total nos dois casos.

ao fenômeno da reflexăo total e da refraçăo.

ao fenômeno da reflexáo regular e reflexăo difusa.

ao fenômeno da reflexăo regular nos dois casos.

Figura 32 - Captura da tela da questão. 


\section{A imagem 1 refere-se}
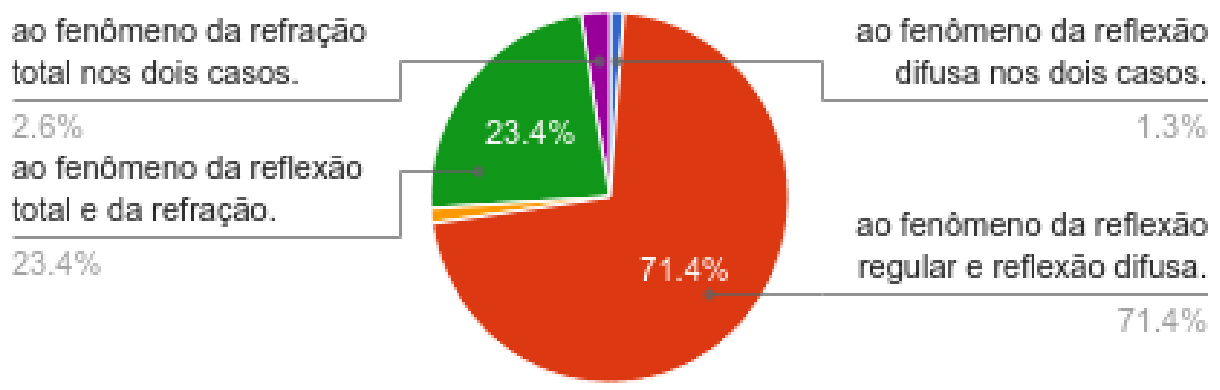

Gráfico 5 - Distribuição das respostas da questão 1. Fonte: Gráfico gerado pela autora na aplicação do formulário de sondagem.

Imagem 2

Foto: eanaj_mila_will

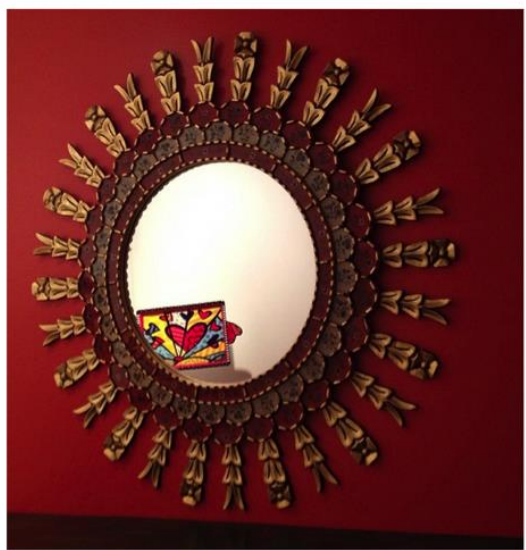

A imagem 2 refere-se*

ao fenômeno da refraçăo e reflexăo total.

ao fenômeno da reflexáo total.

a a fenômeno da reflexáo difusa, näo havendo neste caso reflexáo especular.

ao fenômeno da reflexáo regular e da reflexăo difusa.

ao fenômeno da refraçáo total.

Figura 33 - Captura da tela da questão 2.

\section{A imagem 2 refere-se}

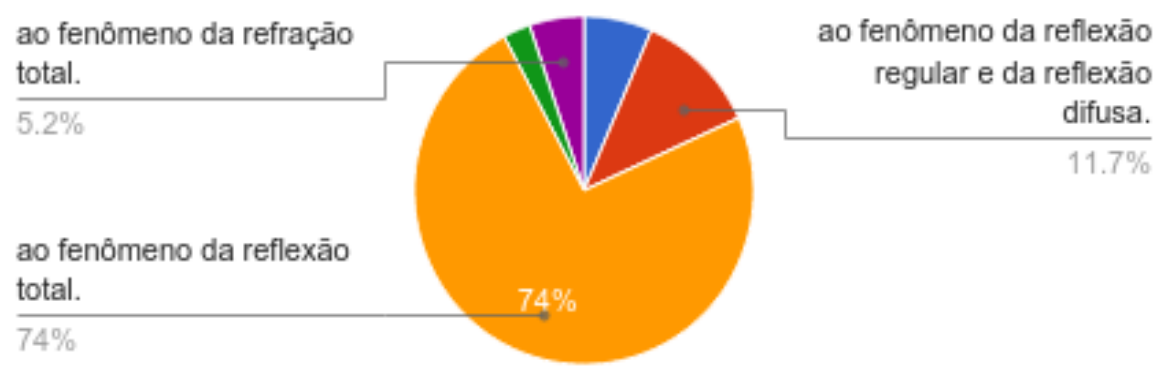

Gráfico 6 - Distribuição das respostas da questão 2. Fonte: Gráfico gerado pela autora na aplicação do formulário de sondagem. 


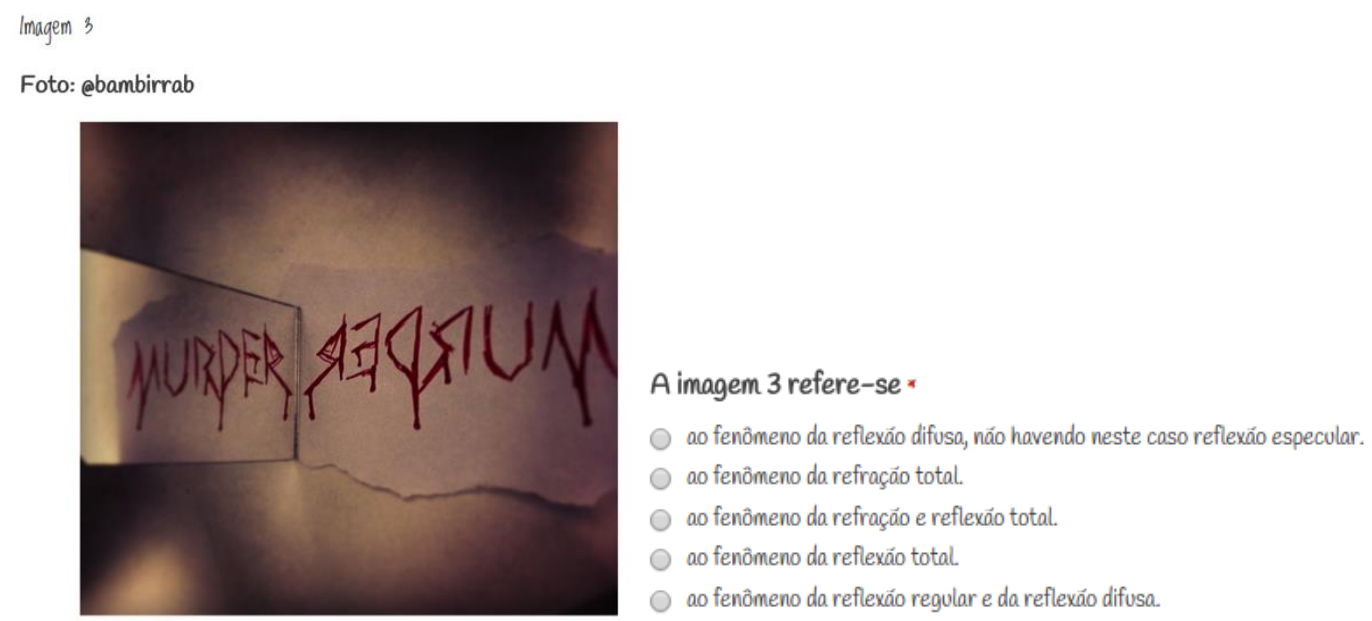

Imagem 12 - Captura da tela da questão 3.

\section{A imagem 3 refere-se}

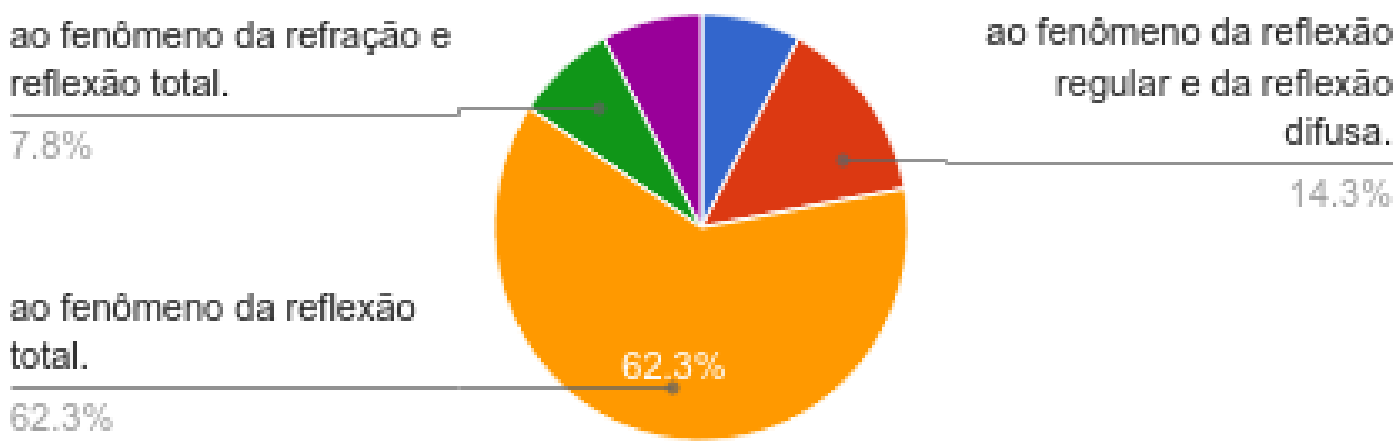

Gráfico 7 - Distribuição das respostas da questão 3. Fonte: Gráfico gerado pela autora na aplicação do formulário de sondagem.

O objetivo das questões 1, 2 e 3 era verificar se o estudante era capaz de diferenciar o fenômeno da reflexão especular [regular] do fenômeno da reflexão difusa. Foram elaboradas três questões abordando o mesmo tema para confrontar as respostas ao acaso e a existência de alguma compreensão sobre tema abordado. Dessa forma, a resposta correta para os itens era: ao fenômeno da reflexão regular e difusa. Observa-se que na questão 1 a maioria, $71,4 \%$, dos estudantes marcaram a opção correta demostrando que, em geral, conseguem diferenciar os dois fenômenos. 
No entanto, como a primeira imagem mostra um reflexo perfeito da taça, percebe-se que cerca de $23,4 \%$ dos alunos acabaram optando pela resposta: ao fenômeno da reflexão total e da refração. Sendo assim, podemos concluir primeiramente que alguns estudantes desconheciam totalmente o fenômeno da reflexão total e da refração, confundindo conceitos importantes relacionados aos fenômenos ópticos.

Em relação à questão 2, podemos observar que apesar desse item apresentar um fenômeno corriqueiro, um espelho pendurado em uma parede refletindo a imagem de uma bolsa colorida, percebemos que a maioria dos alunos, $74 \%$, escolheram como opção de resposta o fenômeno da reflexão total. 0 resultado nos leva a acreditar que o índice de acerto da primeira questão pode ter sido causado por eliminação e/ou acerto ao acaso.

A questão 3 tem resultados semelhantes ao da questão 2, ou seja, a maioria, neste caso, $62,3 \%$ dos estudantes, acredita que o fenômeno apresentado é resultado da reflexão total. É valido notar que, no caso da questão 2, cerca de $11,7 \%$ e, no caso da questão $3,14,3 \%$ dos estudantes acertam o item, o que nos remete à pesquisa realizada por David Hestenes e Ibrahim Halloun publicada no American Journal of Physics, em 1985, em que divulgam que, em uma sala de aula, cerca de $10 \%$ dos estudantes são capazes de aprender os conteúdos que lecionamos independente da presença de um professor. Nossa intenção com este projeto é fazer com que mais estudantes alcancem esse patamar de protagonistas do seu processo de aprendizagem.

Agora faremos a análise das questões 4, 5, 6 e 7 que abordam o tópico espelhos esféricos. Optamos por imagens de vários tipos de espelhos esféricos, inclusive os não gaussianos, tendo em vista que o objetivo era conhecer as estruturas cognitivas do estudante a respeito de situações cotidianas do fenômeno da reflexão da luz e do processo de formação de imagens dos espelhos esféricos. 


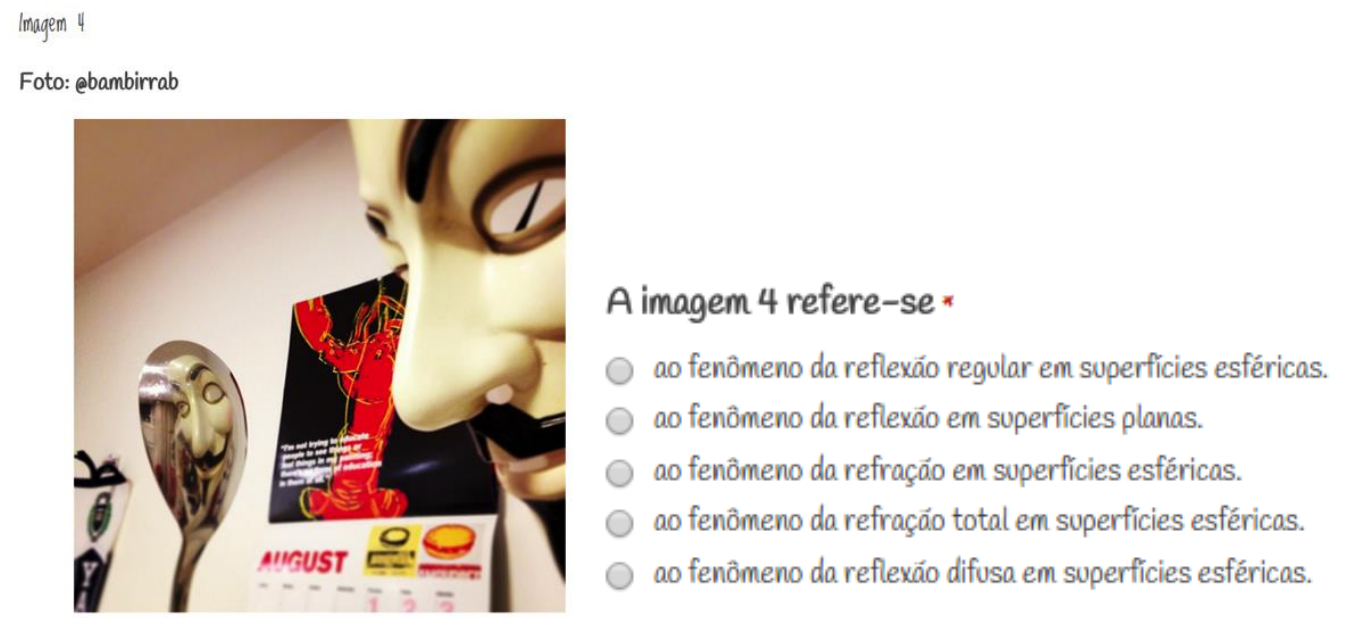

Figura 34 - Captura da tela da questão 4.

\section{A imagem 4 refere-se}

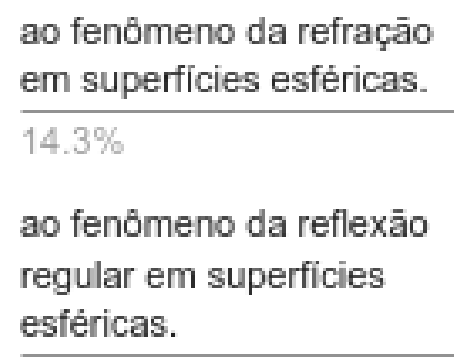

$46.8 \%$

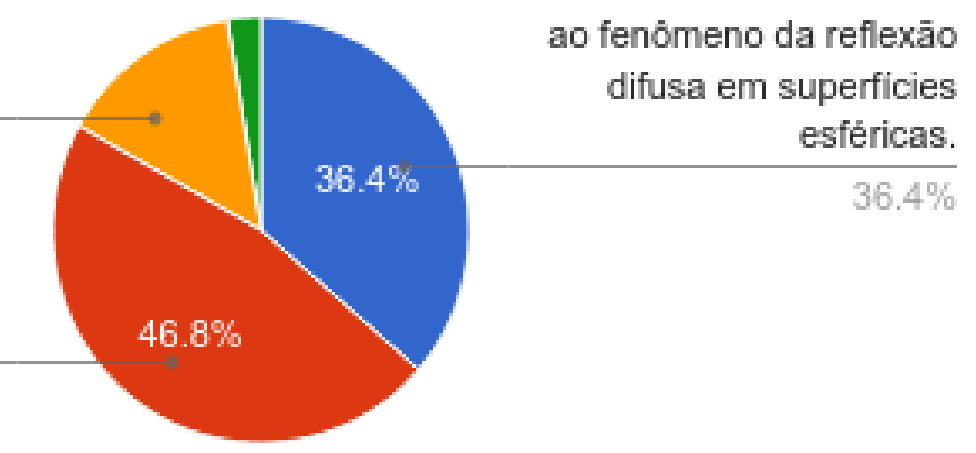

Gráfico 8 - Distribuição das respostas da questão 4. Fonte: Gráfico gerado pela autora na aplicação do formulário de sondagem.

A questão 4 apresenta o fenômeno da reflexão da luz em espelhos esféricos sem classificá-lo, portanto, a resposta correta era: ao fenômeno da reflexão regular em superfícies esféricas. A distribuição das respostas nos mostra que cerca de metade dos estudantes, 46,8\%, reconhece como correta essa afirmação. No entanto, $36,4 \%$ dos alunos consideram que o fenômeno é resultado da reflexão difusa, demonstrando mais uma vez que os estudantes não conhecem o conceito. Neste item, ainda é importante ressaltar que um grupo de $14,3 \%$ afirma que o fenômeno apresentado se trata da refração da luz. 
Imagen 5

Foto: @arte_estheraragao

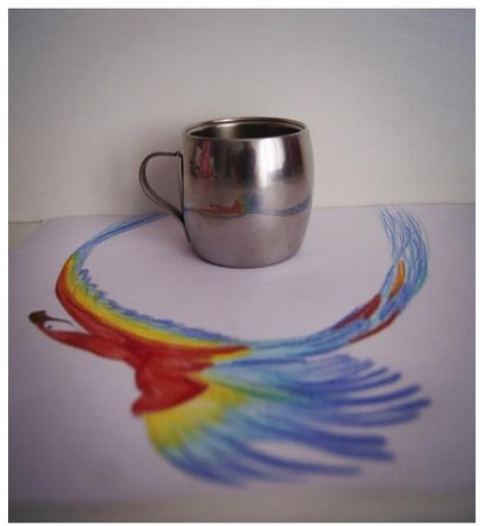

$A$ imagem 5 refere-se *

ao fenômeno da reflexáo regular em espelhos côncavos.

a a fenômeno da reflexáo difusa em espelhos convexos.

ao fenômeno da reflexăo regular em espelhos convexos.

ao fenômeno da refraçăo em espelhos côncavos.

ao fenômeno da refraçáo total em espelhos côncavos.

Figura 35 - Captura da tela da questão 5.

\section{A imagem 5 refere-se}

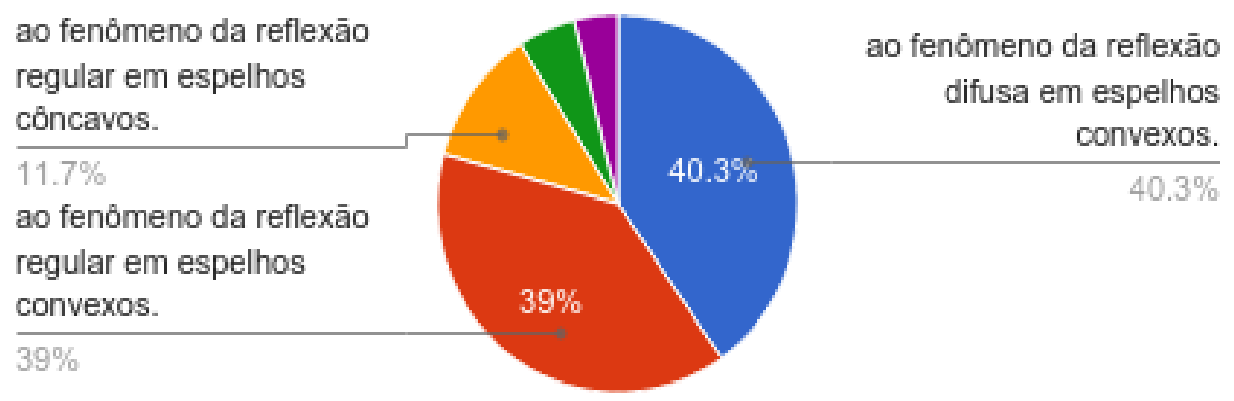

Gráfico 9 - Distribuição das respostas da questão 5. Fonte: Gráfico gerado pela autora na aplicação do formulário de sondagem.

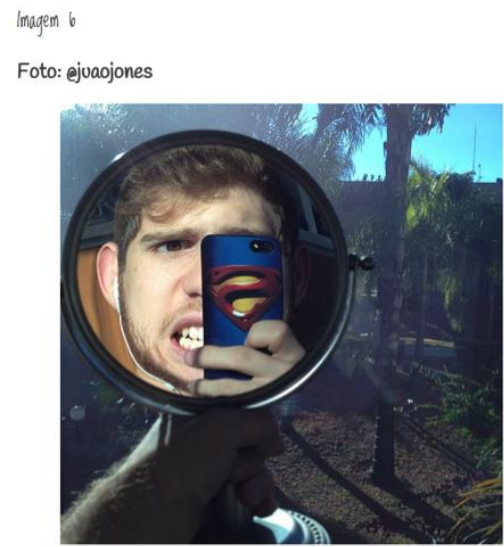

A imagem 6 refere-se *

ao fenômeno da reflexáo difusa em espelhos convexos.

a co fenômeno da refraçáo em espelhos côncavos.

ao fenômeno da refraçáo total em espelhos côncavos.

- ao fenômeno da reflexáo regular em espelhos côncavos.

- ao fenômeno da reflexáo regular em espelhos convexos.

Figura 36 - Captura da tela da questão 6. 


\section{A imagem 6 refere-se}

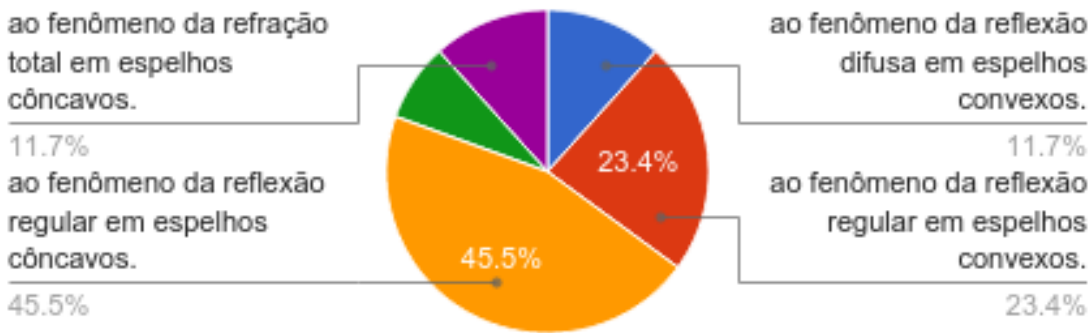

Gráfico 10 - Distribuição das respostas da questão 6. Fonte: Gráfico gerado pela autora na aplicação do formulário de sondagem.

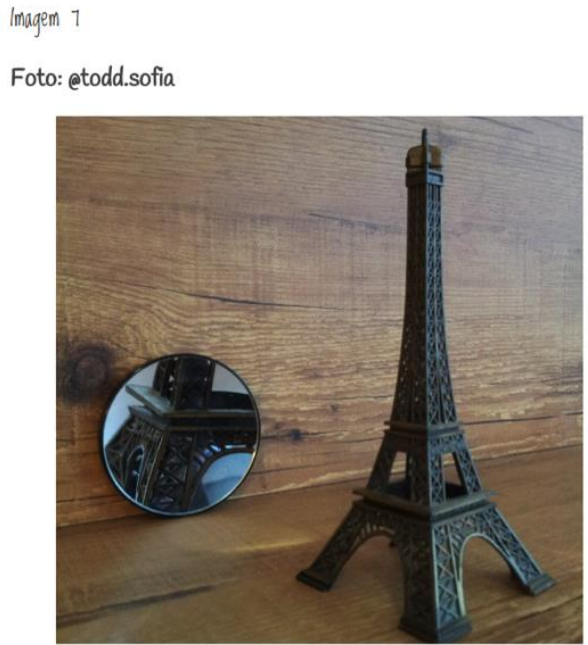

A imagem 7 refere-se *

ao fenômeno da reflexáo regular em espelhos convexos.

ao fenômeno da refraçăo em espelhos côncavos.

ao fenômeno da reflexăo difusa em espelhos convexos.

ao fenômeno da refraçăo total em espelhos côncavos.

ao fenômeno da reflexáo regular em espelhos côncavos.

Figura 37 - Captura da tela da questão 7.

\section{A imagem 7 refere-se}

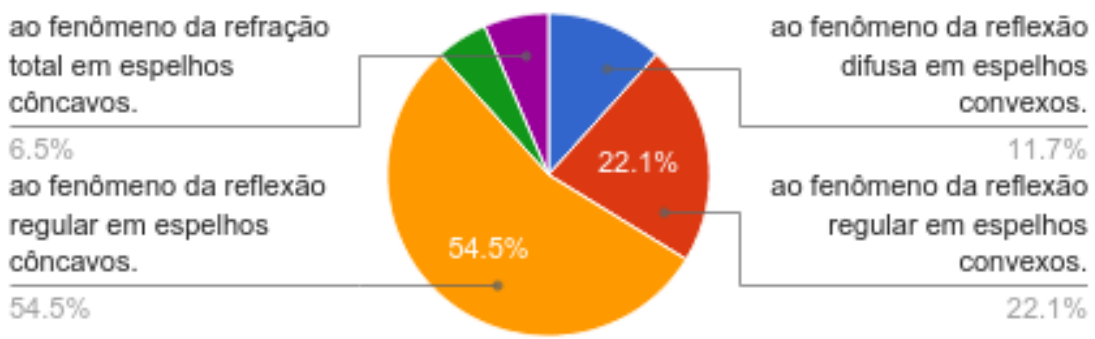

Gráfico 11 - Distribuição das respostas da questão 7. Fonte: Gráfico gerado pela autora na aplicação do formulário de sondagem

As questões 5, 6 e 7 também exploram o fenômeno da reflexão dos espelhos esféricos, no entanto, aqui optou-se por apresentar o nome dos espelhos 
para verificar se o grupo era capaz de diferenciar um espelho côncavo de um espelho convexo. A resposta correta para a questão 5 era: ao fenômeno da reflexão regular em espelhos convexos. É possível verificar uma distribuição mais harmônica no padrão de respostas, 39\% dos estudantes optaram pela resposta correta, referente à questão 5 , enquanto $40.3 \%$ acertaram o tipo do espelho, mas ainda confunde a reflexão difusa com a reflexão regular.

Nas questões 6 e 7, a resposta esperada era: ao fenômeno da reflexão regular em espelhos côncavos, cerca de $45,5 \%$ dos estudantes marcaram o item correto para a questão 6 e 54.5\% marcaram o item correto para a questão 7 , ainda é possível perceber estudantes, 23,4\%, referente à questão 6 e 22,1\% quanto à questão 7 , escolhendo a opção correta com relação ao tipo de reflexão, mas sem conseguir identificar o tipo de espelho que gera a imagem virtual, direita e maior.

A análise desse padrão de respostas nos permite inferir que os estudantes do ensino médio, em geral, não encontram dificuldades na classificação dos espelhos, mas desconhecem o processo de formação das imagens nesses dispositivos ópticos.

As questões 8, 9 e 10 exploram a associação de espelhos planos em diversas situações. Aqui procurou-se explorar a diferença entre os espelhos esféricos e os espelhos planos. Dessa forma a resposta esperada era: ao fenômeno da reflexão regular numa associação de espelhos planos.

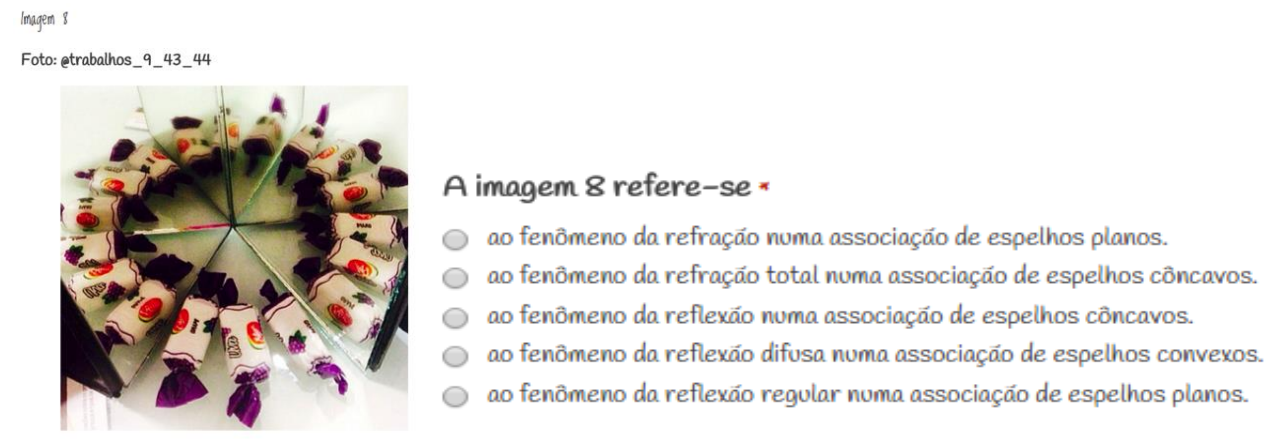

Figura 38 - Captura da tela da questão 8. 


\section{A imagem 8 refere-se}

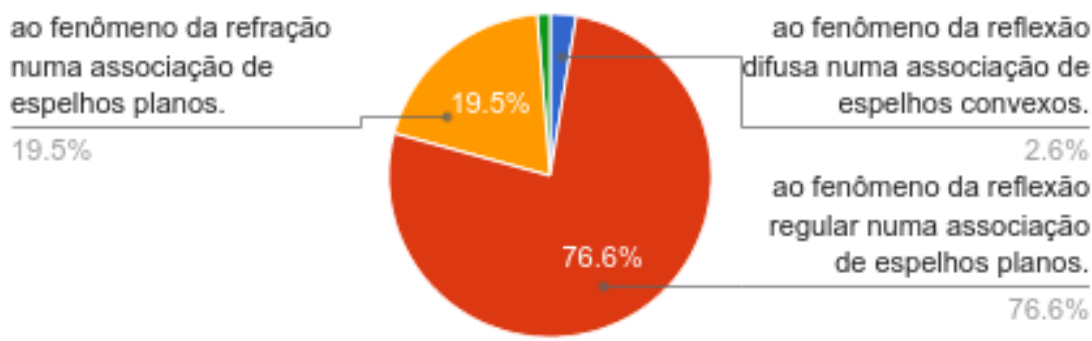

Gráfico 12 - Distribuição das respostas da questão 8. Fonte: Gráfico gerado pela autora na aplicação do formulário de sondagem

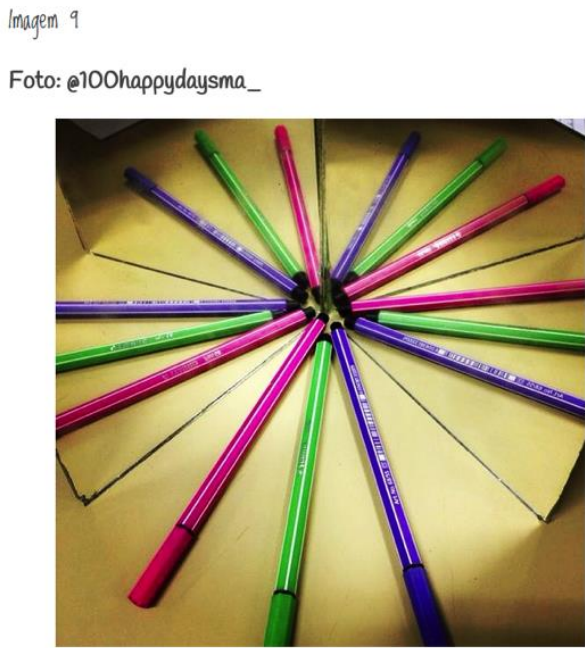

A imagem 9 refere-se *

ao fenômeno da refraçáo numa associaçáo de espelhos planos.

a cenômeno da reflexáo difusa numa associaçăo de espelhos convexos.

ao fenômeno da reflexăo numa associaçăo de espel hos côncavos.

ao fenômeno da reflexáo regular numa associaçăo de espelhos planos.

ao fenômeno da refraçăo total numa associaçáo de espelhos côncavos.

Figura 39 - Captura da tela da questão 9.

\section{A imagem 9 refere-se}

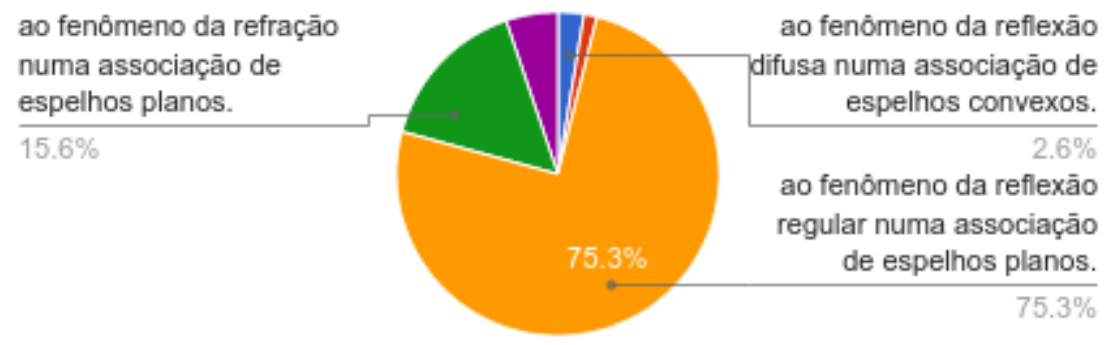

Gráfico 13 - Distribuição das respostas da questão 9. Fonte: Gráfico gerado pela autora na aplicação do formulário de sondagem 


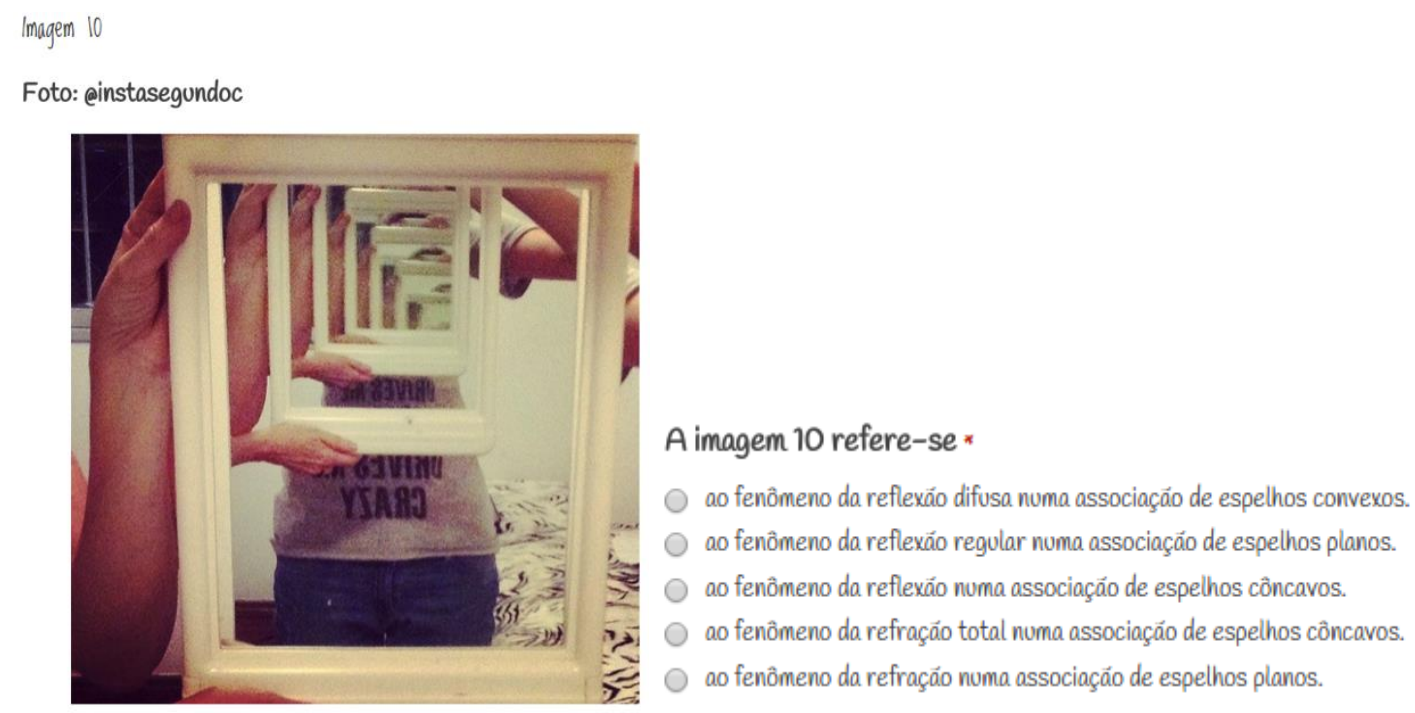

Figura 40 - Captura da tela da questão 10.

\section{A imagem 10 refere-se}

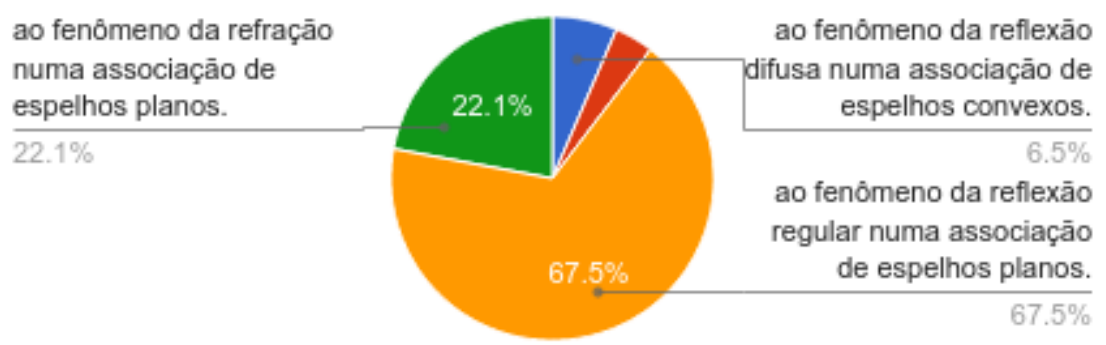

Gráfico 14 - Distribuição das respostas da questão 10. Fonte: Gráfico gerado pela autora na aplicação do formulário de sondagem

Analisando os resultados das questões 8 e 9, podemos perceber que são praticamente idênticos, ou seja, $76,6 \%$ dos estudantes marcaram o item correto para a questão 8 e 75,3\% marcaram o item correto para a questão 9.

$\mathrm{Na}$ questão 10, podemos perceber uma pequena diminuição neste percentual, $67,5 \%$. Acreditamos que o fenômeno ocorra devido à dificuldade de se encontrar nos livros didáticos um exemplo de associação de espelhos paralelos. Lembramos que durante essa atividade os estudantes tinham acesso livre à internet e ao livro e que, em geral, as imagens anteriores são apresentadas como exemplos nas duas vias. 
Há ainda um percentual que chama atenção na opção sobre o fenômeno da refração - 19,5\% para a questão $8,15,6 \%$ para a questão 9 , e 22,1\% para a questão 10 - mostrando que é imprescindível auxiliar os alunos a perceber a diferença entre os dois fenômenos.

As questões 11 e 12 abordaram o fenômeno da dispersão da luz num prisma. O objetivo era verificar se os estudantes reconheciam o fenômeno.

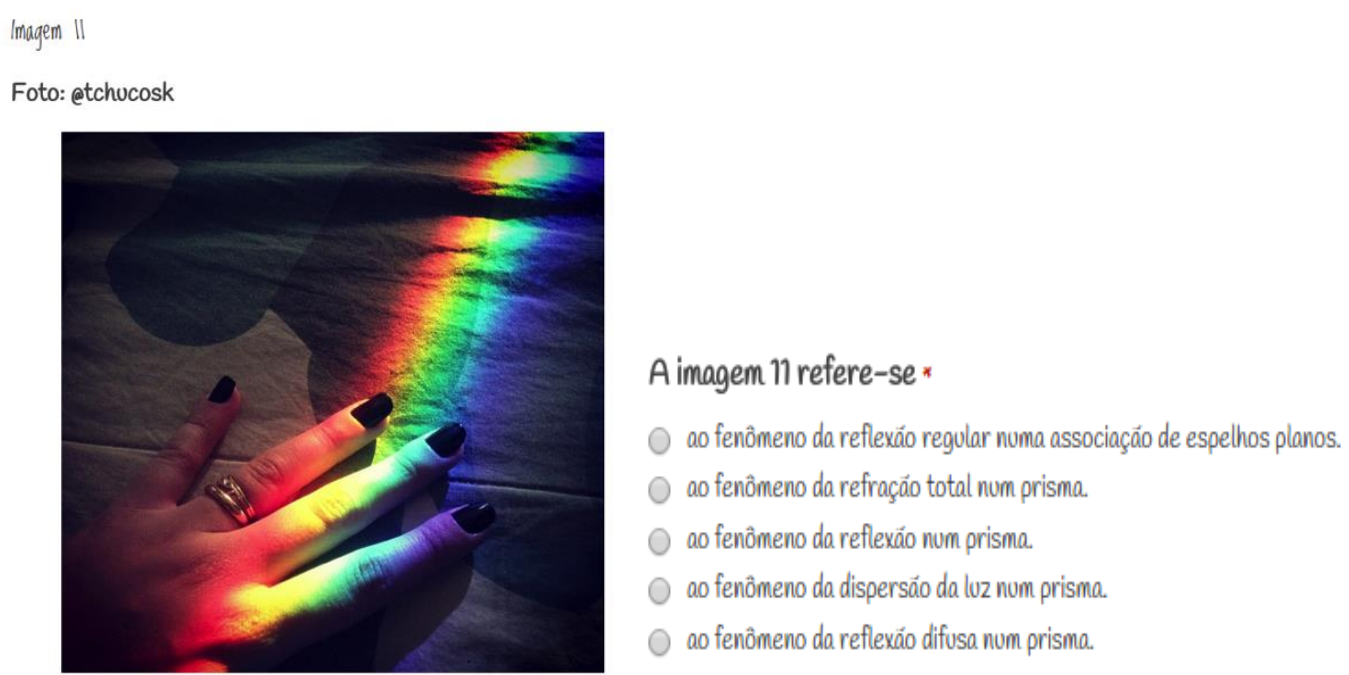

Figura 41 - Captura da tela da questão 11.

\section{A imagem 11 refere-se}

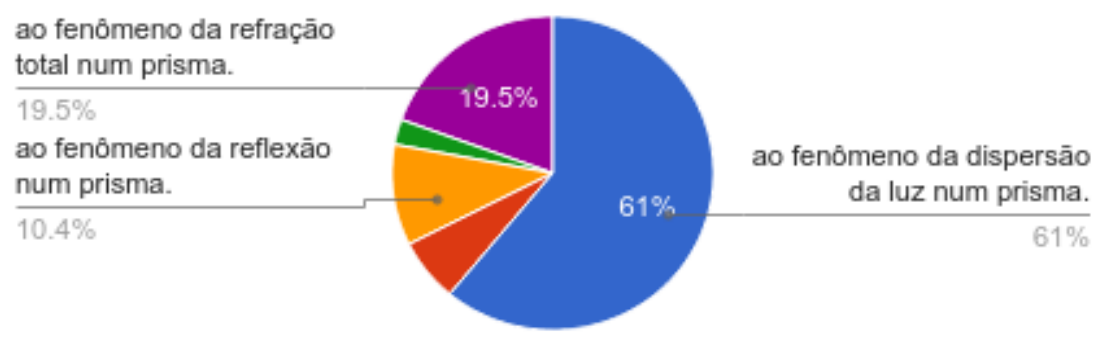

Gráfico 15 - Distribuição das respostas da questão 11. Fonte: Gráfico gerado pela autora na aplicação do formulário de sondagem 


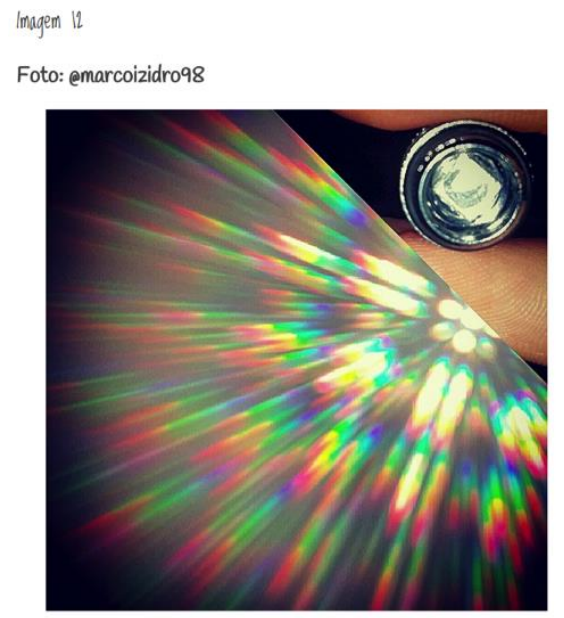

A imagem 12 refere-se *
ao fenômeno da reflexăo difusa num prisma.
ao fenômeno da dispersáo da luz num prisma.
ao fenômeno da reflexáo regular numa associaçáa de espelhos planos.
ao fenômeno da reflexáo num prisma.
ao fenômeno da refraçáo total num prisma.

Figura 42 - Captura da tela da questão 12

\section{A imagem 12 refere-se}

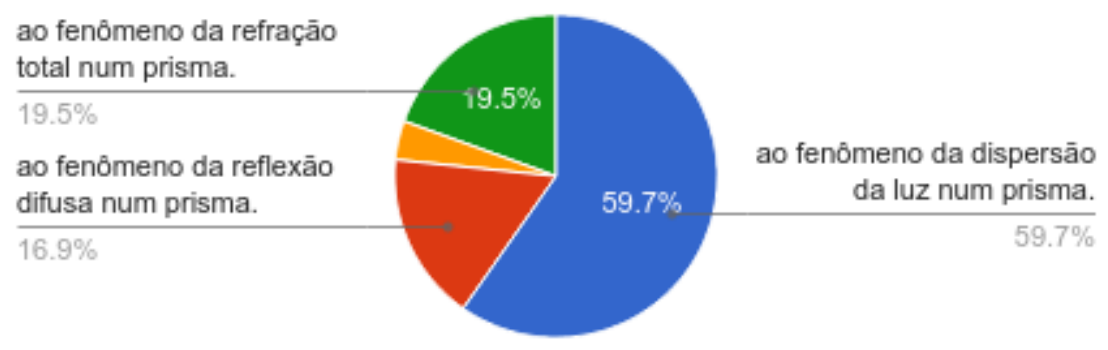

Gráfico 16 - Distribuição das respostas da questão 12. Fonte: Gráfico gerado pela autora na aplicação do formulário de sondagem

O percentual de acerto das questões é bem considerável, cerca de $61 \%$ e $59,7 \%$ dos estudantes acertaram a resposta para as questões 11 e 12 . É interessante constar que cerca de 19,5\%, em ambas as questões, referiram-se a um fenômeno que não existe. Mais uma vez, entendemos que o alto índice de acerto esteja ligado a disponibilidade de imagens sobre o tema na rede mundial de computadores e nos livros didáticos.

As questões 13, 14 e 15 referem-se às lentes esféricas. Optou-se por utilizar imagens que comparavam as lentes de bordas finas, ou seja, comportamento convergente, com as lentes de bordas grossas, comportamento divergente, ambas mergulhadas no ar. 


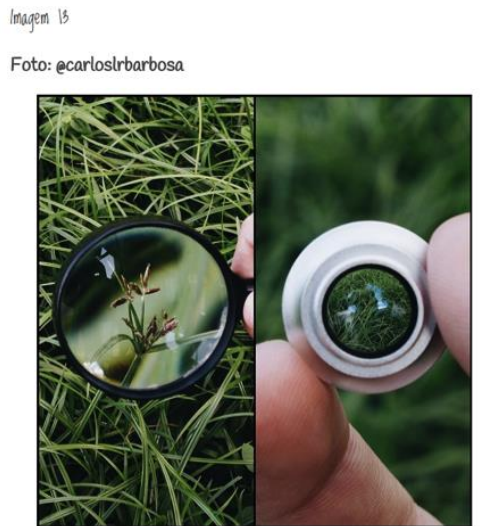
A imagem 13 refere-se *
ao fenômeno da reflexáo em lentes esféricas. A lente da esquerda é convergente e a da direita divergente.
ao fenômeno da reflexáo difusa em lentes esféricas. A lente da esquerda é divergente e a da direita convergente.
a cenômeno da reflexáo regular em lentes esféricas. A lente da esquerda é divergente e a da direita convergente
ao fenômeno da dispersáo da luz em lentes esféricas. A lente da esquerda é convergente e a da direita divergente.
ao fenômeno da refraçáo em lentes esféricas. A lente da esquerda é convergente e a da direita divergente

Figura 43 - Captura da tela da questão 13.

\section{A imagem 13 refere-se}

\begin{abstract}
ao fenômeno da refraçāo em lentes esféricas. A lente da esquerda é convergente e a da direita divergente $35.1 \%$
\end{abstract}
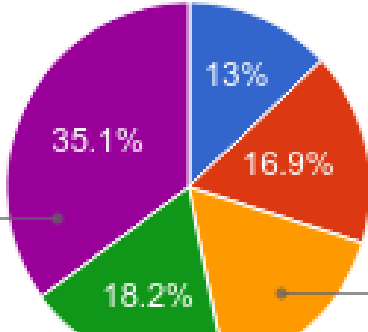

ao fenômeno da reflexāo em lentes esféricas. A lente da esquerda è convergente $\mathrm{e}$ a da direita divergente. $16.9 \%$

Gráfico 17 - Distribuição das respostas da questão 13. Fonte: Gráfico gerado pela autora na aplicação do formulário de sondagem

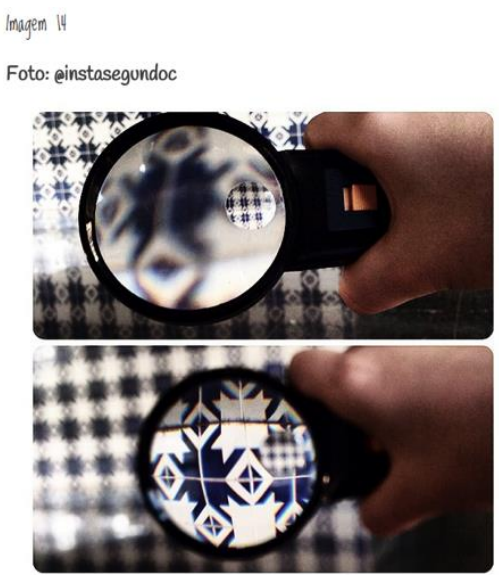

A imagem 14 refere-se*

- ao fenômeno da reflexáo difusa em lentes esféricas. A lente da cima é convergente e a de baixo divergente.

ao fenômeno da refraçáa em lentes esféricas. Ambas sắo convergentes.

- ao fenômeno da reflexáo em lentes esféricas. A lente da cima é convergente e a de baixo divergente.

a a fenômeno da dispersăo da luz em lentes esféricas. Ambas săo convergentes.

ao fenômeno da reflexắo regular em lentes esféricas. Ambas sáo divergentes.

Figura 44 - Captura da tela da questão 14. 


\section{A imagem 14 refere-se}

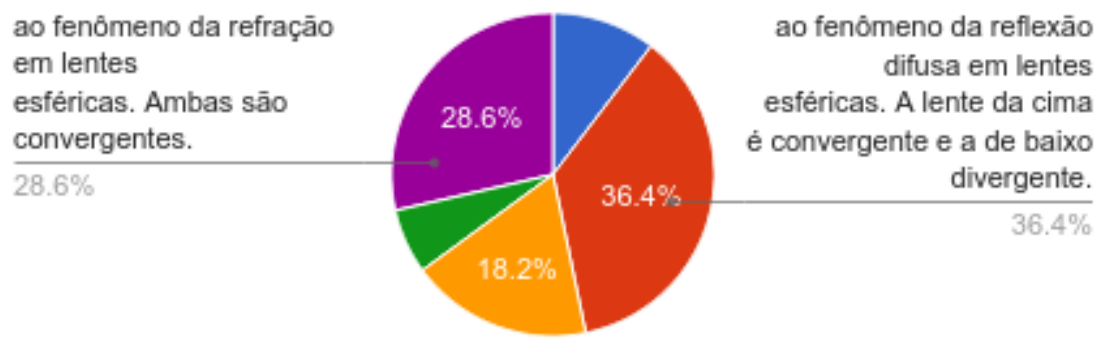

Gráfico 18 - Distribuição das respostas da questão 14. Fonte: Gráfico gerado pela autora na aplicação do formulário de sondagem

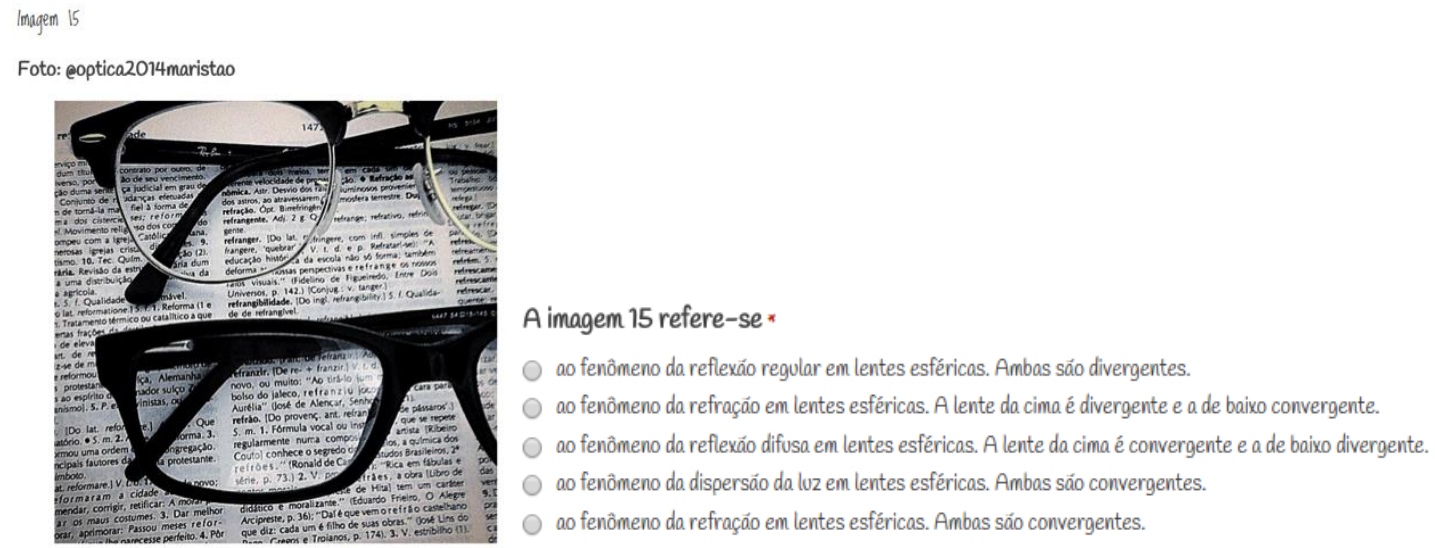

Figura 45 - Captura da tela da questão 15.

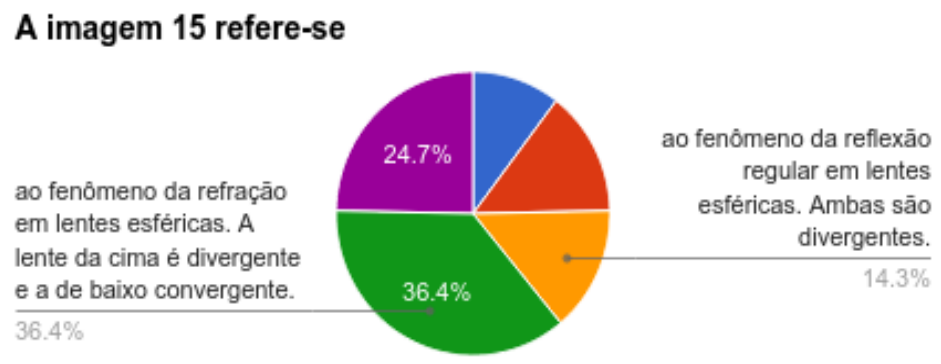

Gráfico 19 - Distribuição das respostas da questão 15. Fonte: Gráfico gerado pela autora na aplicação do formulário de sondagem.

Analisando as questões 13, 14 e 15, podemos perceber que os estudantes, em geral, não diferenciam o fenômeno da reflexão do fenômeno da refração. Sendo assim, percebemos um percentual de acerto abaixo da expectativa, a 
saber, $35,1 \%, 28,6 \%$ e $36,4 \%$ respectivamente. Mais uma vez, ressaltamos que em geral os livros didáticos não apresentam o conteúdo mediante o uso de imagens desta natureza, restringindo-se, na maioria das vezes, aos esquemas gráficos, o que nos leva a concluir que os estudantes não conseguem relacionar esses esquemas com a representação cotidiana do fenômeno. Os dados denotam que os estudantes não possuem discernimento dos fenômenos ópticos comuns, sendo, portanto, importante fazer um pós-teste após a aplicação do projeto para verificar se essa diferenciação passa a ser atribuída pelo corpo discente.

Para completar esta análise e com efeito de comparação, foi feita a correção da sondagem por meio de um complemento conhecido como FLUBAROO $^{14}$, que nos permitiu analisar quantitativamente as notas que os estudantes tiraram na atividade. Essa avaliação não foi apresentada para os alunos, servindo apenas de referência para esta dissertação, no quadro abaixo podemos observar o resumo com os resultados dos estudantes.

\begin{tabular}{|l|r|}
\hline \multicolumn{2}{|c|}{ Resultados - Sondagem } \\
\hline Pontos possíveis & 30 \\
\hline Pontuação média & 13,79 \\
\hline Número de formulários submetidos & 77 \\
\hline
\end{tabular}

Quadro 11 - Média das notas alcançadas na atividade de sondagem.

As notas correspondem a média aritmética da pontuação obtida pelos estudantes de 0 a 30 pontos e mostram que, em média, eles ficaram abaixo dos $50 \%$ de rendimento. A sondagem foi aplicada após a apresentação do projeto para os estudantes, momento em que eles foram informados da necessidade de se verificar o que sabiam sobre o assunto. Todos foram orientados a consultar os livros e a rede mundial de computadores. Os estudantes fizeram as atividades utilizando os computadores disponíveis na escola, seus dispositivos pessoais, tais

14 Trata-se de um complemento que pode ser adicionado às planilhas geradas pelo Google Forms para fazer a correção automática das atividades. Para auxiliar os professores no uso deste complemento foi elaborado uma vídeo-aula disponível no link bit.ly/flubaroocomsamara 
como tablets e smartphones, tranquilamente durante a aula, mostrando-se sempre curiosos a respeito do tema.

Os resultados apresentados nos levam a perceber que cada estudante possui um sistema de crenças e intuições sobre fenômenos físicos que são oriundos de sua experiência pessoal. Esse sistema funciona como uma teoria do senso comum a respeito do mundo físico e o aluno a utiliza para interpretar fenômenos. Esse sistema de crenças deve ser o principal determinante que 0 estudante usa para aprender durante o curso. No entanto, o ensino tradicional parece falhar quase completamente por não levar esta informação em conta [Hestenes e Halloun, 1985].

\subsection{Aula de apresentação do Álbum Digital}

Nesta etapa, os estudantes estavam desafiados a apresentar o seu álbum para a turma, discutindo a veracidade das informações que encontraram para explicar os fenômenos, ou seja, era necessário apresentar a foto no Datashow informando o fenômeno abordado. A turma foi instigada pelos professores a avaliar a veracidade das informações apresentadas. Em geral a receptividade das turmas é muito boa durante esta discussão, tendo em vista que se veem na condição de disseminador de conhecimento e se sentem na responsabilidade de apresentá-los de maneira adequada.

Quando havia alguma incoerência que não era percebida pela turma, o tema era imediatamente abordado pelos professores e tratado com a turma para esclarecimento de dúvidas e devidas correções. Em geral, o próprio grupo reconhecia que não havia pesquisado profundamente sobre o tema, ou que realmente não havia compreendido o fenômeno.

A ideia de apresentar o trabalho para a turma é pautada nas estruturas cognitivas desenvolvidas por meio das metodologias ativas de ensino, em que o estudante é o centro do processo de aprendizagem. Neste caso, optamos por 
adaptar a metodologia desenvolvida por Eric Mazur conhecida como peer instruction ou instrução pelos pares, que tem por objetivo promover o desenvolvimento de conhecimento em rede, ou seja, rizomaticamente [Deleuze e Guattarri, 1995]. Ao promover a discussão dos estudantes com os seus pares, ou seja, seus colegas de classe, o tópico abordado é, em geral, apresentado utilizando-se uma linguagem mais adequada à idade dos estudantes, o que faz com que eles compreendam mais facilmente determinados conteúdos.

\subsection{Da avaliação do projeto}

O Processo de avaliação de projetos compreende uma etapa extremamente complexa, tanto para professores quanto para estudantes, pois, em geral, projetos dessa natureza são avaliados qualitativamente, o que, segundo a visão desta educadora, por vezes gera uma expectativa ruim nos estudantes, tendo em vista que há sempre a dúvida por parte dos estudantes se o professor está avaliando o projeto pautado nas suas perspectivas emocionais. Para evitar e diminuir a insegurança dos estudantes numa análise meramente qualitativa que resulte numa nota, para este projeto propusemos uma rubrica criada no Google Forms conforme modelo a seguir.

\begin{tabular}{|l|l|}
\hline \multicolumn{2}{|l|}{ Rubrica para Avaliação de Projeto em Fotos } \\
\hline Estrutura & Pontuação Possível \\
\hline Critério & 0,3 pontos \\
\hline Hashtag \#albumdigital2015 & 0,3 pontos \\
\hline Hashtag referente à turma & 0,4 pontos \\
\hline Hashtag original para o grupo & \\
\hline Avaliação da Foto & Pontuação Possível \\
\hline Critério
\end{tabular}




\begin{tabular}{|l|l|}
\hline Qualidade das imagens & 1 ponto \\
\hline Pertinência e correção da identificação e descrição & 3 pontos \\
\hline Originalidade na escolha das fotos e na apresentação & 2 pontos \\
\hline \multicolumn{2}{|l}{} \\
\hline Para 6 fotos o valor total do projeto será & 37 pontos \\
\hline
\end{tabular}

Quadro 12 - Rubrica de avaliação. Créditos: Autora

Dessa forma, a avaliação de cada foto foi realizada durante a apresentação marcando-se a escala abaixo:

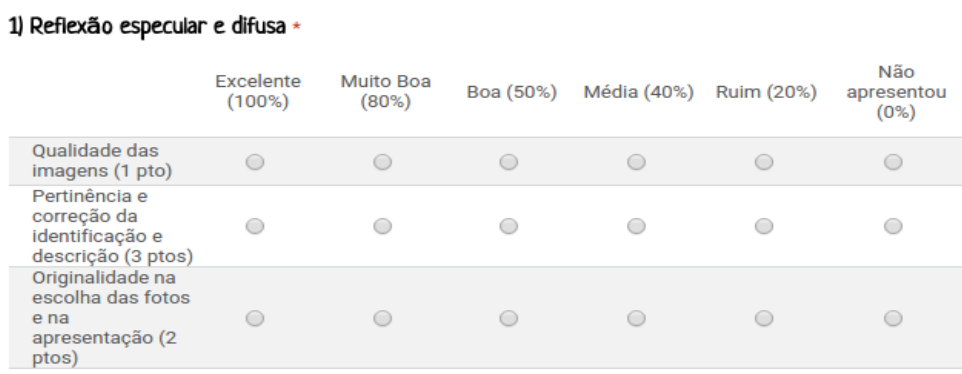

Figura 46 - Captura da tela da escala utilizada para avaliação do projeto.

As marcações coletadas pelo formulário são convertidas automaticamente numa tabela conforme apresentada abaixo.

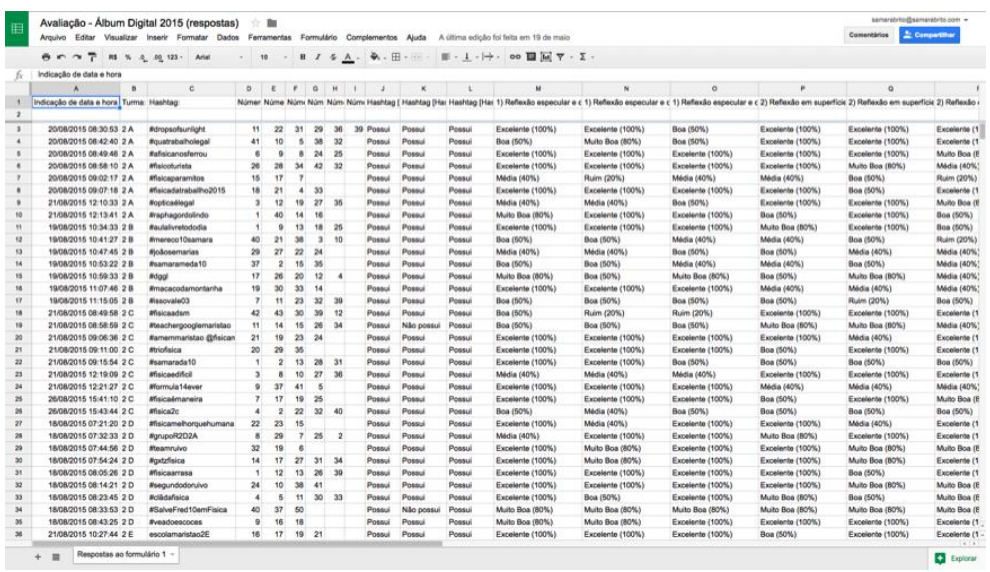

Quadro 13 - Captura de tela da tabela gerada para avaliação do projeto. ${ }^{15}$

\footnotetext{
${ }^{15}$ Imagem meramente ilustrativa, para ter acesso aos dados completos da tabela acesse o link bit.ly/tabelacompleta
} 
A Tabela apresentada pode ser facilmente preparada para calcular a nota dos estudantes. Foram utilizadas as ferramentas substituir para converter as opções Excelente, Muito Boa, Boa, Média e Ruim em números e em seguida uma expressão para calcular a nota de 0 a $10^{16}$, conforme modelos abaixo.

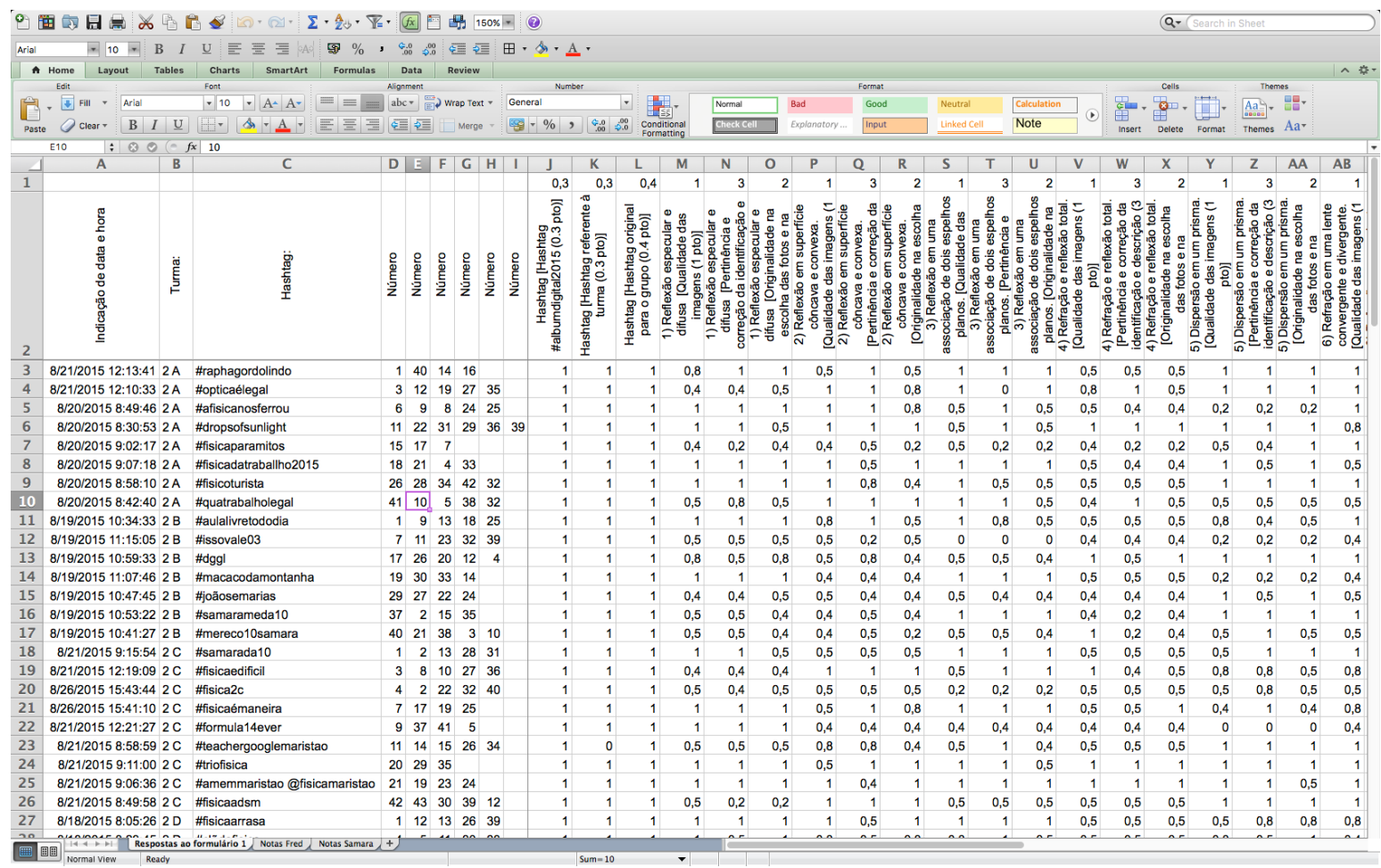

Quadro 14 - Planilha utilizada para dar notas aos estudantes no projeto. ${ }^{17}$

Dessa forma, ao final das apresentações de todas as turmas o professor pode entregar as notas aos estudantes esclarecendo a pontuação que obtiveram.

\subsection{Pós-teste}

Para verificar o processo de aprendizagem, optou-se, nesta proposta didática, por aplicar o mesmo questionário da sondagem no pós-teste. A ideia é demostrar se, após a realização do projeto, os estudantes passam a reconhecer

${ }_{16}$ Uma vídeo-aula foi elaborada para auxiliar os professores nesse processo que está disponível no link bit.ly/avaliandoprojetoscomsamara

17 Figura meramente ilustrativa para ter acesso a planilha inteira acesse bit.ly/notasalbumdigital2015 
os fenômenos em seu cotidiano. Durante o período de realização do projeto, as turmas continuaram a ter aulas tradicionais de óptica, ou seja, abordou-se o tema durante as aulas expositivas e na ocasião da correção de exercícios. Observouse, durante este período, que os estudantes estavam mais motivados a descobrir como se comportavam dispositivos ópticos, sempre fazendo referência aos conteúdos que estavam pesquisando para o projeto.

O pós-teste foi aplicado após a aula de apresentação das fotos para a turma, durante esta aula os estudantes não puderam consultar o material. $O$ resultado do pós-teste está apresentado nas imagens e gráficos a seguir.

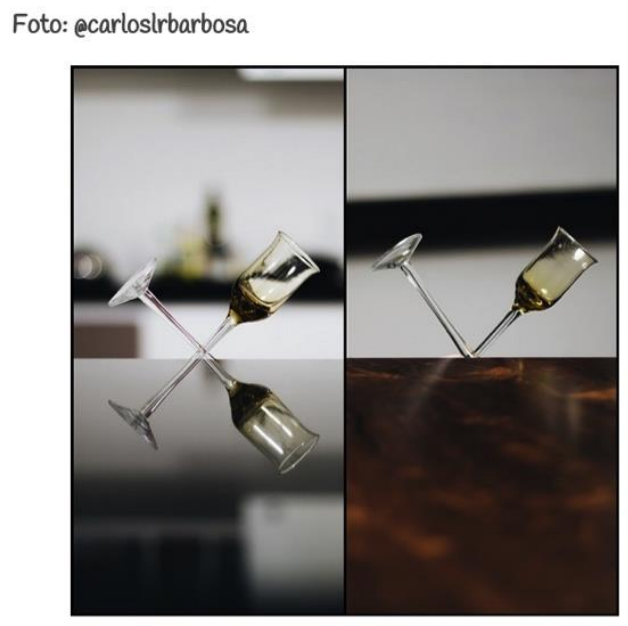

A imagem 1 refere-se *

ao fenômeno da reflexáo difusa nos dois casos.

ao fenômeno da refraçáo total nos dois casos.

ao fenômeno da reflexáo total e da refraçăo.

ao fenômeno da reflexăo regular e reflexăo difusa.

ao fenômeno da reflexăo regular nos dois casos.

Figura 47 Captura da tela da questão. ${ }^{18}$

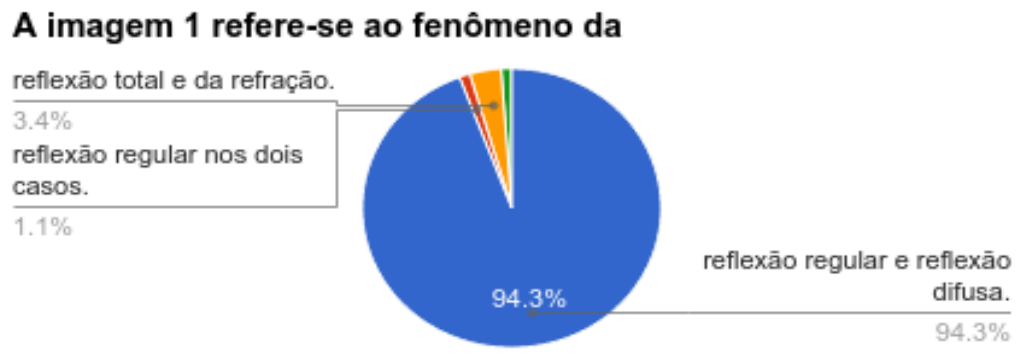

Gráfico 20 - Distribuição das respostas da questão 1 - Pós-teste.

\begin{tabular}{lcccccc}
\hline 18 & 0 & formulário & completo está disponível no link: \\
https://sites.google.com/a/samarabrito.com/fenomenos-opticos/sondagem
\end{tabular}


Imagem 1

Foto: eanaj_mila_will

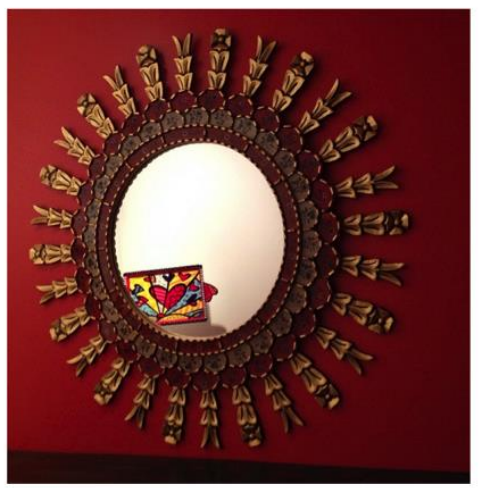

A imagem 2 refere-se *

ao fenômeno da refraçáo e reflexăo total.

ao fenômeno da reflexáo total.

ao fenômeno da reflexăo difusa, náo havendo neste coso reflexăo especular.

a conômeno da reflexáo regular e da reflexăo difusa.

ao fenômeno da refraçáo total.

Figura 48 - Captura da tela da questão 2.

\section{A imagem 2 refere-se ao fenômeno da}

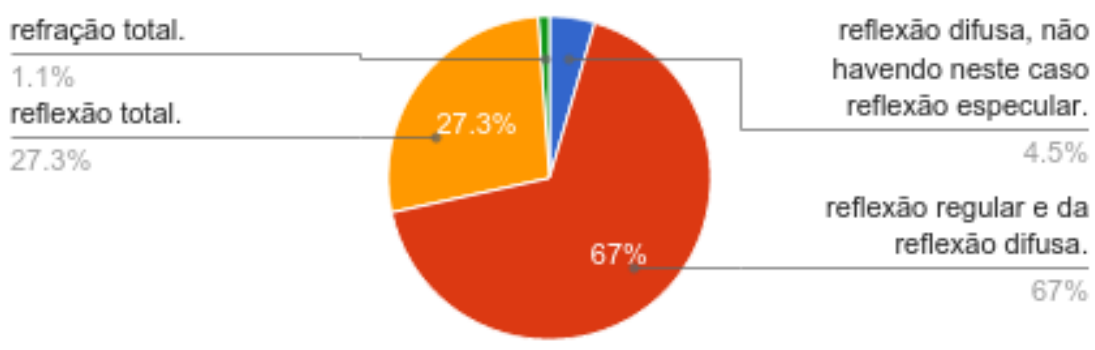

Gráfico 21 - Distribuição das respostas da questão 2 - Pós-teste.

Imagem 3

Foto: @bambirrab

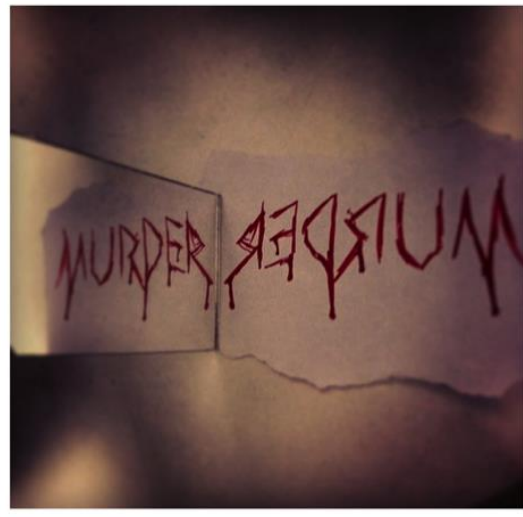

A imagem 3 refere-se *

a conômeno da reflexáo difusa, náo havendo neste caso reflexáo especular.

ao fenômeno da refraçăo total.

ao fenômeno da refraçáo e reflexăo total.

ao fenômeno da reflexáo total.

ao fenômeno da reflexáo regular e da reflexăo difusa.

Figura 48 - Captura da tela da questão 3. 


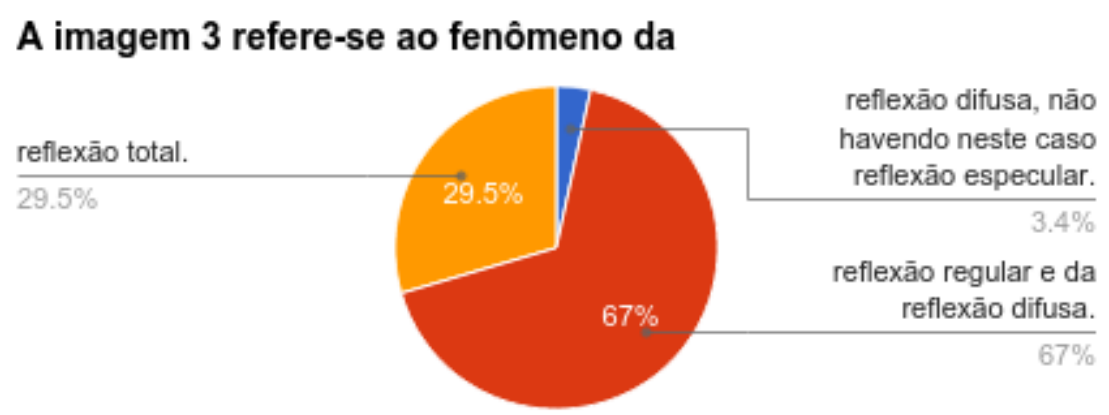

Gráfico 22 - Distribuição das respostas da questão 3 - Pós-teste.

Conforme citado anteriormente, o objetivo das questões 1, 2 e 3 era verificar se o estudante era capaz de diferenciar o fenômeno da reflexão especular [regular] do fenômeno da reflexão difusa. Portanto, a resposta esperada para os itens era: ao fenômeno da reflexão regular e difusa.

Na sondagem, o percentual de acerto para a questão 1 foi de $71,4 \%$, já, no pós-teste, alcançou-se $94,3 \%$ de acerto, o que mostre que a partir de então mais estudantes conseguem diferenciar os dois fenômenos. Na questão 2, que tratava de um fenômeno corriqueiro, um espelho pendurado em uma parede refletindo a imagem de uma bolsa colorida, percebemos que houve uma diminuição considerável no percentual de estudantes que escolheram como opção de resposta o fenômeno da reflexão total - na sondagem $74 \%$ e no pós-teste apenas $27,3 \%$ - o que demostra que o projeto contribuiu efetivamente na diferenciação entre os dois fenômenos.

A questão 3 mais uma vez tem resultados semelhantes ao da questão 2. No entanto, desta vez quanto à marcação da opção correta, $67 \%$ dos estudantes acertam o item. Podemos neste momento perceber a influência positiva do projeto no processo de cognição, já que, antes das atividades, apenas cerca de $10 \%$ dos alunos acertavam as questões. Considerando que durante o projeto a interferência do professor é mínima, podemos inferir que os estudantes ao assumir o papel de protagonistas do seu processo de aprendizagem obtêm excelentes resultados. 
Em seguida, faremos a análise das questões 4, 5, 6 e 7 que abordam o tópico espelhos esféricos. Vejamos os resultados do pós-teste comparados à sondagem.

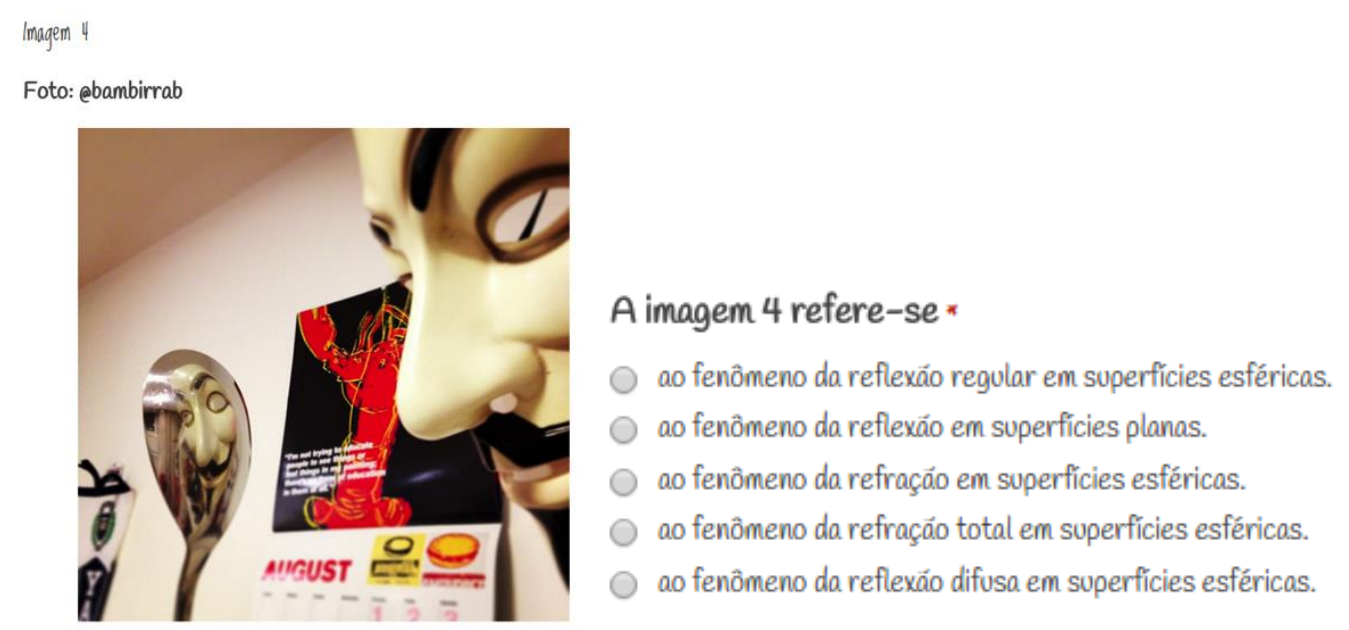

Figura 49 - Captura da tela da questão 4.

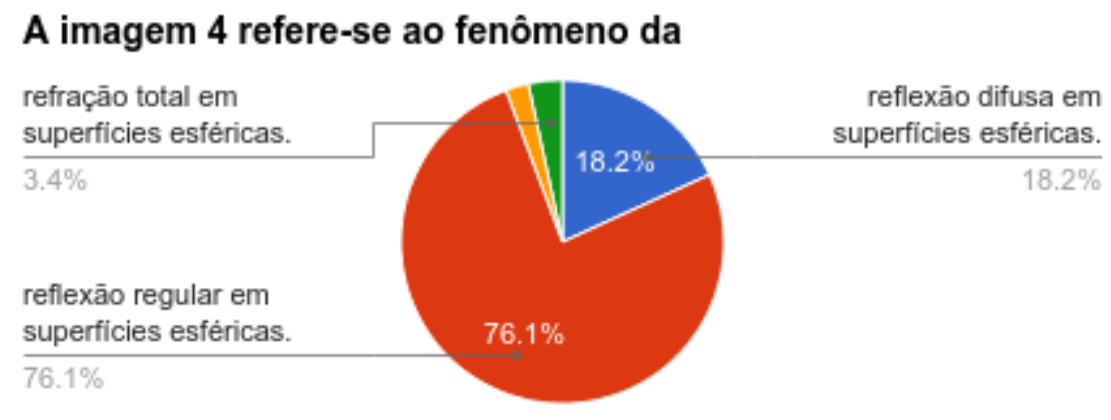

Gráfico 23 - Distribuição das respostas da questão 4 - Pós-teste.

Para a questão 4 a resposta esperada era: ao fenômeno da reflexão regular em superfícies esféricas. Na sondagem, a distribuição das respostas mostrou que cerca de metade dos estudantes, $46,8 \%$, reconhecia como correta essa afirmação. No pós-teste, o valor alcança $76,1 \%$ e o percentual de alunos que considerava que o fenômeno era resultado da reflexão difusa passou de $36,4 \%$ para $18,2 \%$. Essa queda demonstrar como o projeto tem o potencial de mudar a perspectiva do estudante, ajudando-os a ressignificar conceitos. Ainda há um percentual muito pequeno de estudantes que não conhece o fenômeno - na 
sondagem esse valor correspondia a $14,3 \%$ no pós-teste passou para $3,4 \%$ - 0 que vai ao encontro das estatísticas relacionadas aos grupos de estudantes que sofrem de transtornos de aprendizagem [Inhauser et al, 2010], no entanto, consideramos que não constitui base para tal asseveração, mas denota que há um percentual de estudantes que ainda não compreende o fenômeno.

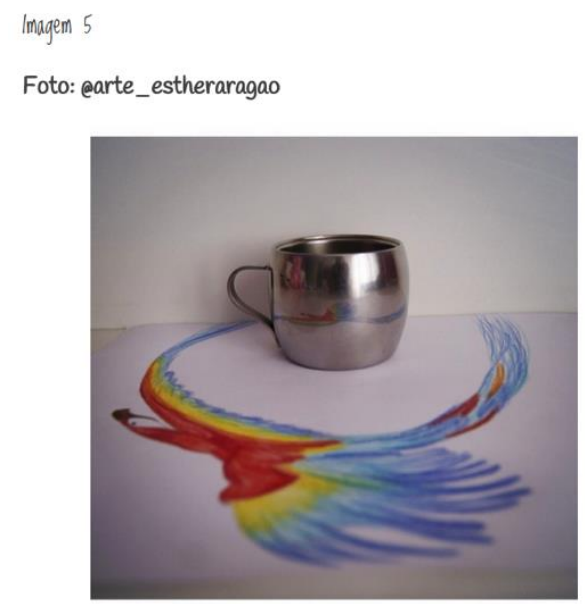

A imagem 5 refere-se *

ao fenômeno da reflexăo regular em espelhos côncavos.

ao fenômeno da reflexáo difusa em espelhos convexos.

ao fenômeno da reflexáo regular em espelhos convexos.

ao fenômeno da refraçăo em espelhos côncavos.

ao fenômeno da refraçáo total em espelhos côncavos.

Figura 50 - Captura da tela da questão 5.

\section{A imagem 5 refere-se ao fenômeno da}

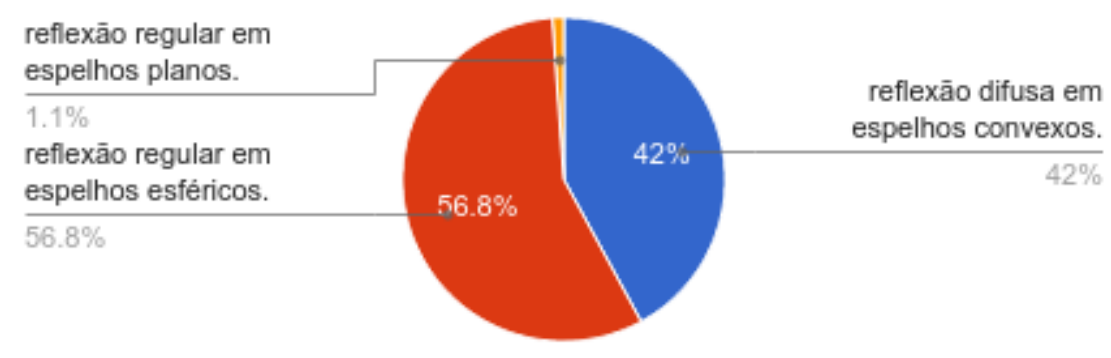

Gráfico 24 - Distribuição das respostas da questão 5 - Pós-teste. 


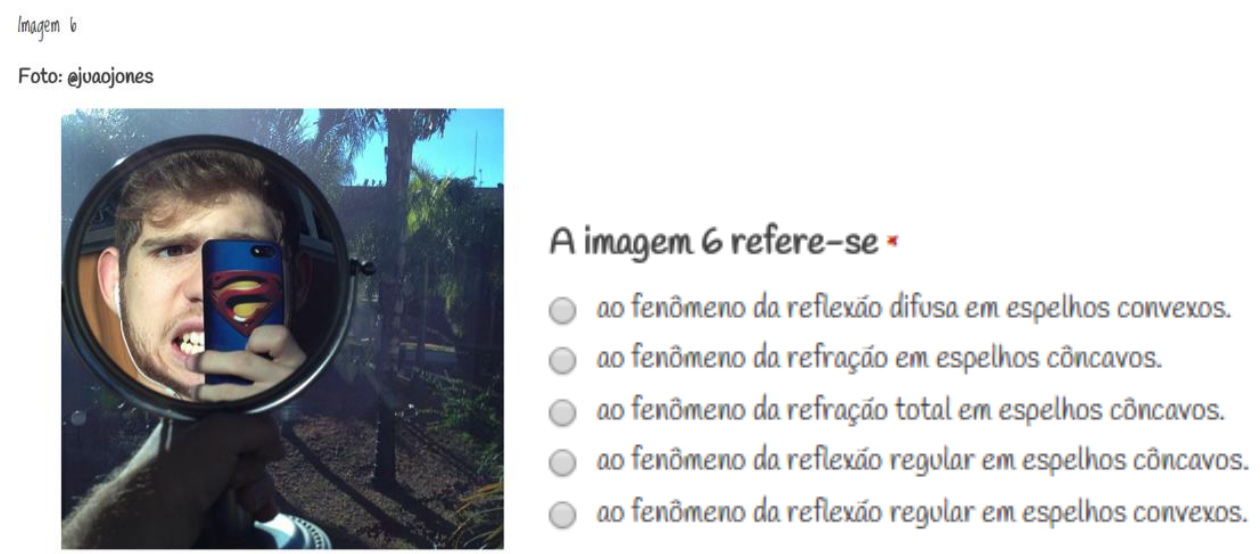

Figura 51 - Captura da tela da questão 6.

\section{A imagem 6 refere-se ao fenômeno da}

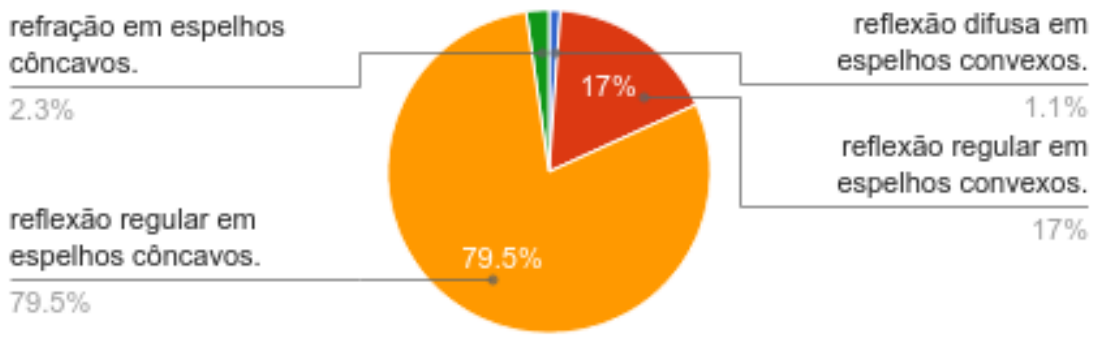

Gráfico 25 - Distribuição das respostas da questão 6 - Pós-teste.

Imagem 1

Foto: etodd.sofia

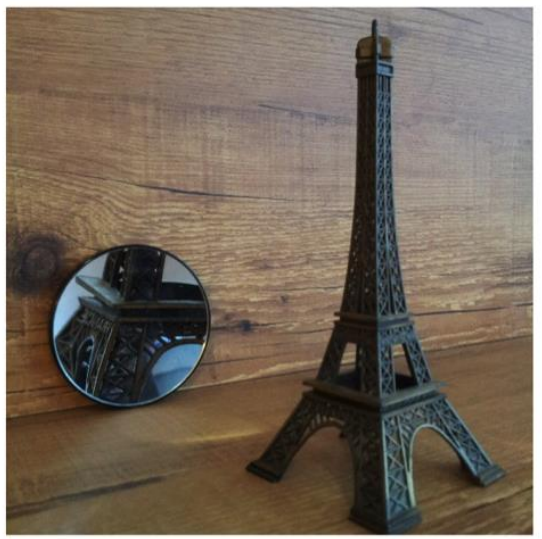

A imagem 7 refere-se *

ao fenômeno da reflexáo regular em espelhos convexos.

ao fenômeno da refraçáo em espelhos côncavos.

ao fenômeno da reflexäo difusa em espelhos convexos.

ao fenômeno da refraçăo total em espelhos côncavos.

a co fenômeno da reflexáo regular em espelhos côncavos.

Figura 52 - Captura da tela da questão 7. 


\section{A imagem 7 refere-se ao fenômeno da}

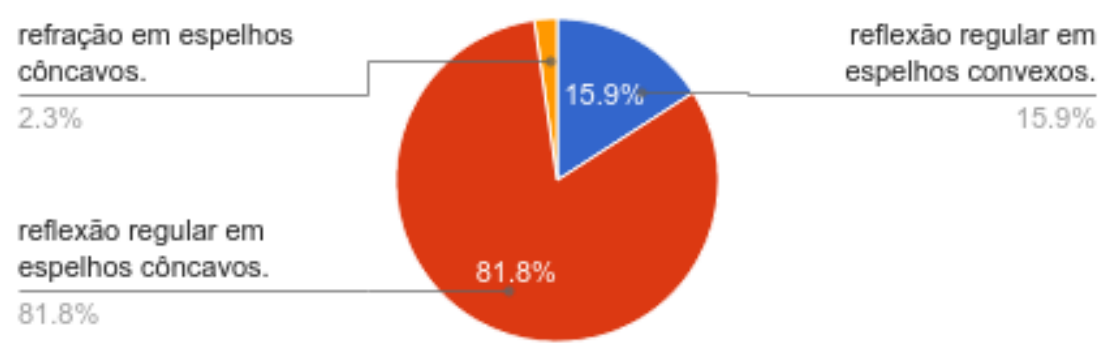

Gráfico 26 - Distribuição das respostas da questão 7 - Pós-teste.

As questões 5, 6 e 7 exploram o fenômeno da reflexão dos espelhos esféricos, de forma a verificar se o grupo era capaz de diferenciar um espelho côncavo de um espelho convexo. A resposta correta para a questão 5 era: ao fenômeno da reflexão regular em espelhos convexos. Na sondagem foi possível verificar uma distribuição harmônica nas respostas, 39\% dos estudantes optaram pela resposta correta, já no pós-teste o percentual subiu para $56,8 \%$. No entanto, metade dos alunos ainda tem dificuldade em diferenciar a reflexão regular da reflexão difusa. O conteúdo foi abordado durante as apresentações.

Nas questões 6 e 7, assim como na sondagem a resposta esperada era: ao fenômeno da reflexão regular em espelhos côncavos, nessa etapa o percentual de acerto que era de 45,5\% passou a ser de 79,5\% para a questão $6 \mathrm{e}$ $81,8 \%$ para a questão 7 , que anteriormente apresentava $54,5 \%$. Ainda é possível perceber estudantes, $17 \%$, referente à questão 6, e 15,9\%, no tocante à questão 7, escolhendo a opção correta com relação ao tipo de reflexão, mas sem conseguir identificar o tipo de espelho. Entretanto, consideramos que esse número é razoável sob o ponto de vista do aprendizado.

Nessa etapa, podemos concluir que o padrão de respostas nos permite inferir que os estudantes do ensino médio, em geral, passaram não só a reconhecer a classificação dos espelhos esféricos, mas também passaram a compreender o processo de formação das imagens nesses dispositivos ópticos. 
As questões 8, 9 e 10, assim como na sondagem exploraram a associação de espelhos planos em diversas situações. Dessa forma, a resposta esperada era: ao fenômeno da reflexão regular numa associação de espelhos planos.

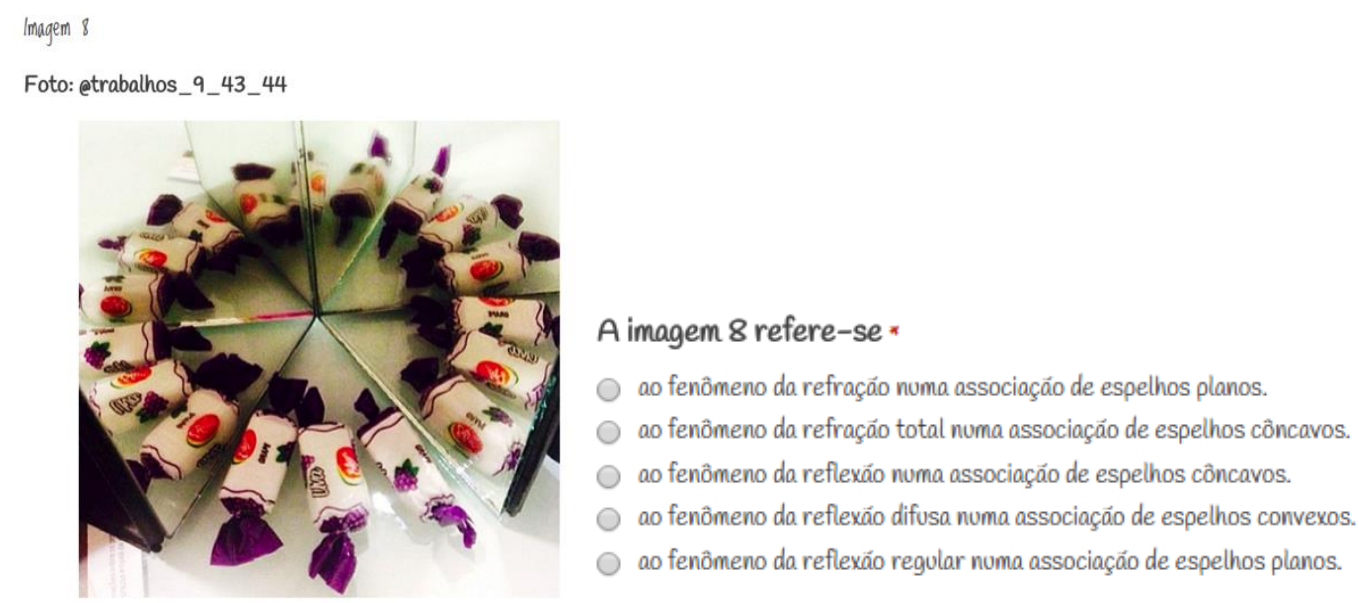

Figura 53 - Captura da tela da questão 8.

\section{A imagem 8 refere-se ao fenômeno da}

refraçāo numa associaçāo de espelhos planos.

$3.4 \%$

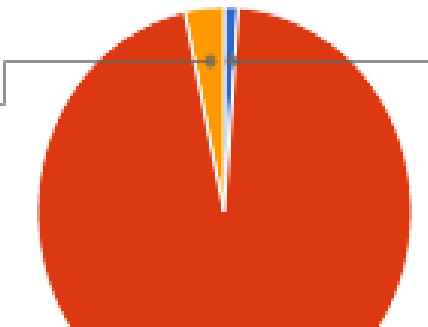

$95.5 \%$

reflexāo numa associaçāo de espelhos cóncavos.

reflexāo regular numa associaçāo de espelhos planos. $95.5 \%$

Gráfico 27 - Distribuição das respostas da questão 8 - Pós-teste. 


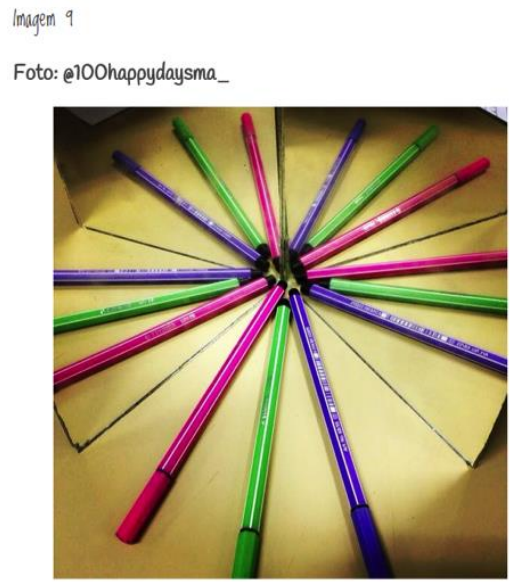

\section{A imagem 9 refere-se *}

ao fenômeno da refraçăo numa associaçáo de espelhos planos.

- ao fenômeno da reflexáo difusa numa associaçăo de espelhos convexos.

ao fenômeno da reflexáo numa associaçăo de espelhos côncavos.

- ao fenômeno da reflexăo regular numa associaçáo de espelhos planos.

ao fenômeno da refraçăo total numa associaçăo de espelhos côncavos.

Figura 54 - Captura da tela da questão 9.

\section{A imagem 9 refere-se ao fenômeno da}

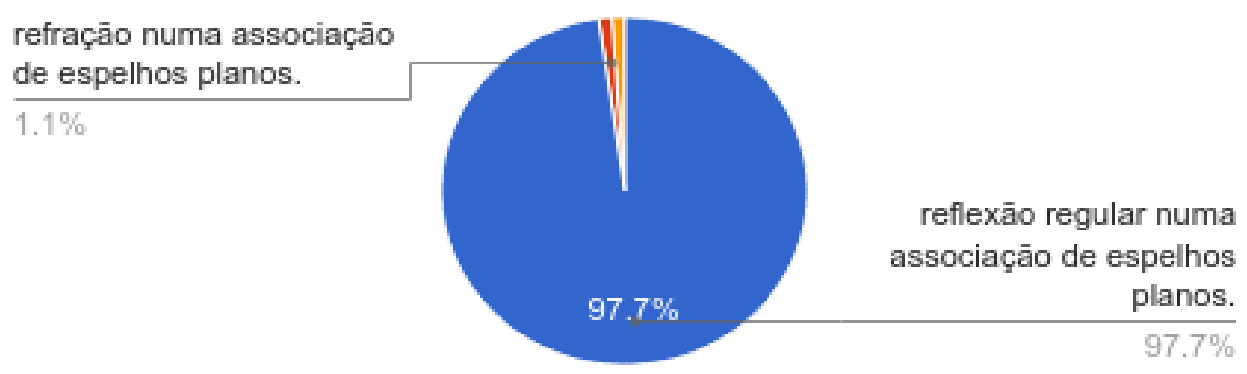

Gráfico 28 - Distribuição das respostas da questão 9 - Pós-teste.

Imagem 10

Foto: einstasegundoc

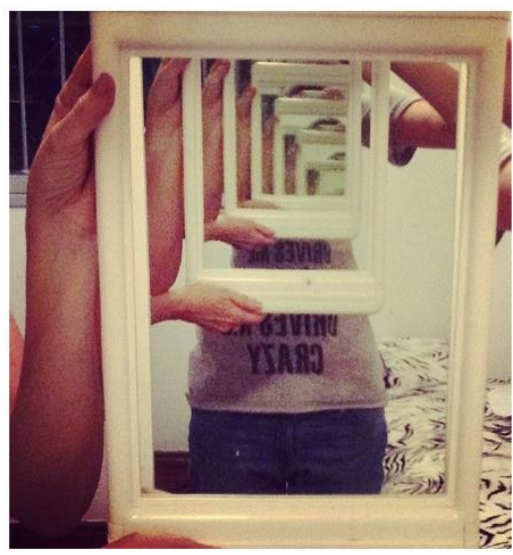

A imagem 10 refere-se *

ao fenômeno da reflexáo difusa numa associaçăo de espelhos convexos.

ao fenômeno da reflexáo regular numa associaçäo de espelhos planos.

a a fenômeno da reflexáo numa associaçáo de espethos côncavos.

a a fenômeno da refraçáo total numa associaçáo de espelhos côncavos.

ao fenômeno da refraçáo numa associaçáo de espelhos planos.

Figura 55 - Captura da tela da questão 10. 


\section{A imagem 10 refere-se ao fenômeno da}

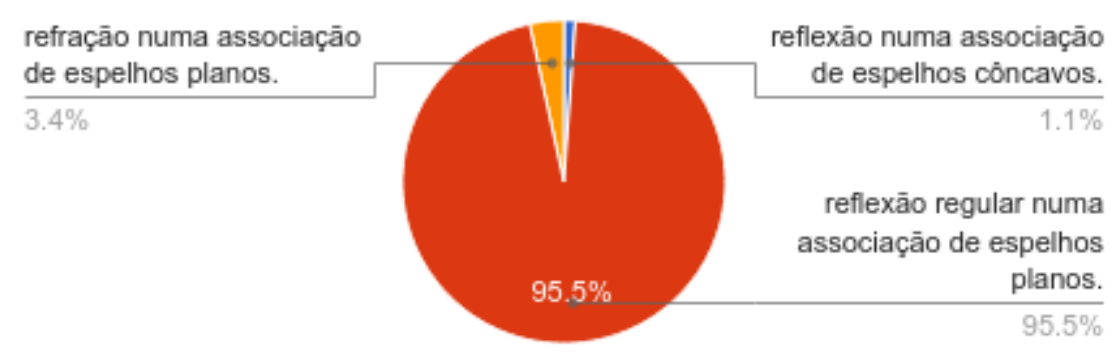

Gráfico 29 - Distribuição das respostas da questão 10 - Pós-teste.

Os resultados do pós-teste, referentes às questões 8 e 9, também são idênticos, ou seja, 95,5\% dos estudantes marcaram o item correto para a questão 8 e 97,7 marcaram o item correto para a questão 9. Na sondagem, o resultado era de $76,6 \%$, no tocante à questão 8 e 75,3\% referente à questão 9. Para a questão 10, a mesma relação, na sondagem $67,5 \%$, no pós-teste $95,5 \%$ de acerto. Nesse caso, acreditamos que a dificuldade antes apresentada está associada ao fato dos livros didáticos não trazerem este tipo de ilustração da associação de espelhos, depois do desenvolvimento do projeto a dificuldade fora resolvida tendo como base a experiência cotidiana.

Com relação ao percentual de alunos que marcou a resposta como sendo o fenômeno da refração, consideramos que a queda de 19,5\% para 3,4\%, referente à questão 8; de 15,6\% para 1,1\%, no atinente à questão 9 e 22,1\% para 3,4\%, no tocante à questão 10, mostra que é possível, considerando a experiência cotidiana, ensinar de modo expressivo os alunos a diferença entre os dois fenômenos.

As questões 11 e 12 no pós-teste também abordaram o fenômeno da dispersão da luz num prisma. O objetivo, mais uma vez, era verificar se os estudantes reconheciam o fenômeno. 


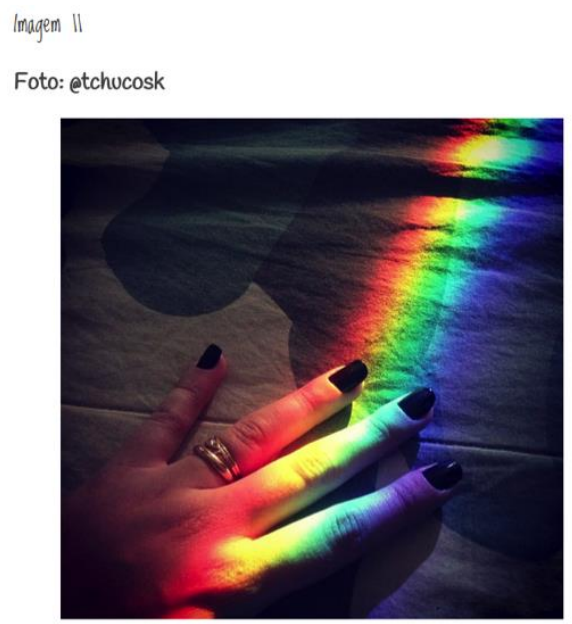

A imagem 11 refere-se *

ao fenômeno da reflexáo regular numa associaçăo de espelhos planos.

ao fenômeno da refraçăo total num prisma.

ao fenômeno da reflexáo num prisma.

ao fenômeno da dispersáo da luz num prisma.

ao fenômeno da reflexăo difusa num prisma.

Figura 56 - Captura da tela da questão 11.

\section{A imagem 11 refere-se ao fenômeno da}

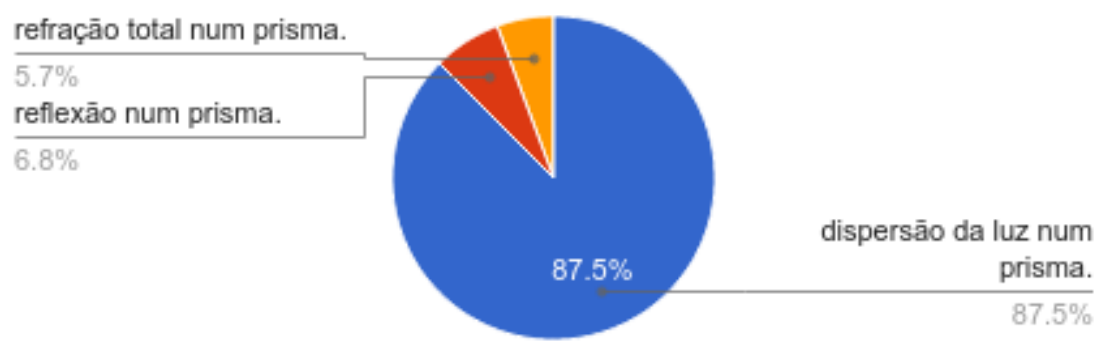

Gráfico 30 - Distribuição das respostas da questão 11 - Pós-teste.

Imagem 12

Foto: emarcoizidro98

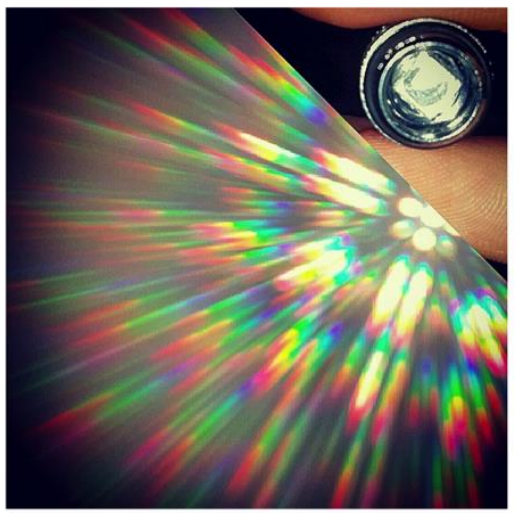

A imagem 12 refere-se *

ao fenômeno da reflexáo difusa num prisma.

a conômeno da dispersáo da luz num prisma.

ao fenômeno da reflexáo regular numa associaçắo de espethos planos.

ao fenômeno da reflexăo num prisma.

ao fenômeno da refraçáo total num prisma.

Figura 57 - Captura da tela da questão 12. 


\section{A imagem 12 refere-se ao fenômeno da}

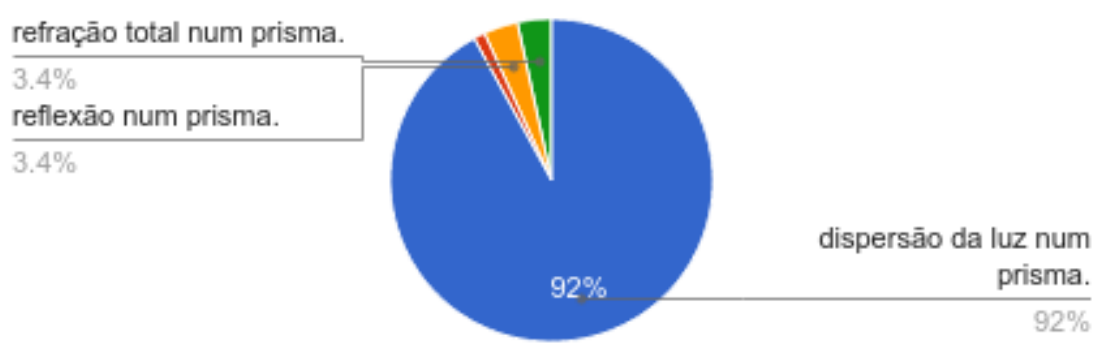

Gráfico 31 - Distribuição das respostas da questão 12 - Pós-teste.

Aqui o percentual de acerto das questões que já era bem considerável, cerca de $61 \%$ e 59,7\%, para as questões 11 e 12, aumentou consideravelmente passando para $87,5 \%$ e $92 \%$ respectivamente. É interessante destacar que, na sondagem, 19,5\% dos estudantes, em ambas as questões se referiram a um fenômeno que não existe, mas, no pós-teste, o índice caiu para 5,7\% e 3,4\%, mostrando mais uma vez, a eficiência do método adotado, associado a disponibilidade de imagens sobre o tema na rede mundial de computadores e nos livros didáticos. As questões 13, 14 e 15 no pós-teste referem-se às lentes esféricas. Vejamos os resultados.

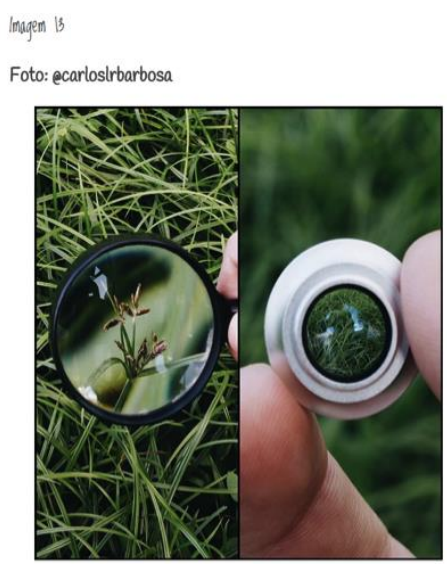

A imagem 13 refere-se*

ao fenômeno da reflexăo em lentes esféricas. A lente da esquerda é convergente e a da direita divergente.

a o fenômeno da reflexăo difusa em lentes esféricas. A lente da esquerda é divergente e a da direita convergente.

O ao fenômeno da reflexáo regular em lentes esféricas. A lente da esquerda é divergente e a da direita convergente

O ao fenômeno da dispersáo da luz em lentes esféricas. A lente da esquerda é convergente e a da direita divergente.

○ ao fenômeno da refraçáo em lentes esféricas. A lente da esquerda é convergente e a da direita divergente

Figura 58 - Captura da tela da questão 13. 


\section{A imagem 13 refere-se ao fenômeno da}

refraçāo em lentes esféricas. A lente da esquerda é convergente e a da direita divergente $52.3 \%$

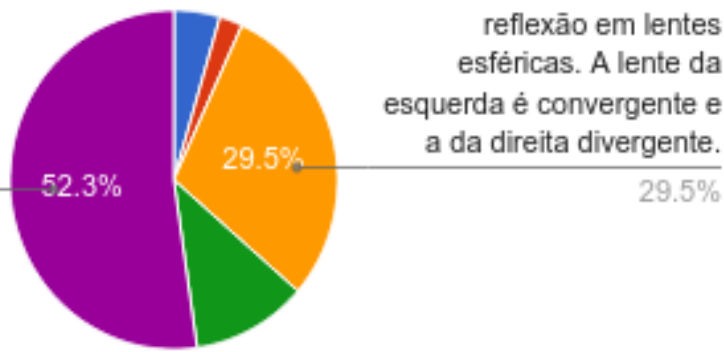

Gráfico 32 - Distribuição das respostas da questão 13 - Pós-teste.

Imagem 14

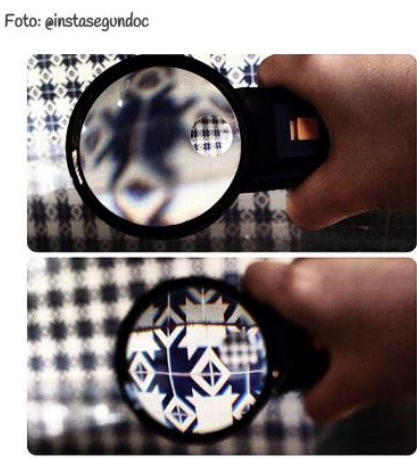

A imagem 14 refere-se *

a o fenômeno da reflexáo difusa em lentes esféricas. A lente da cima é convergente e a de baixo divergente.

ao fenômeno da refraçáo em lentes esféricas. Ambas sáo convergentes.

a a fenômeno da reflexăo em lentes esféricas. A lente da cima é convergente e a de baixo divergente.

ao fenômeno da dispersä́o da luz em lentes esféricas. Ambas sá́o convergentes.

ao fenômeno da reflexăo regular em lentes esféricas. Ambas sáo divergentes.

Figura 59 - Captura da tela da questão 14.

A imagem 14 refere-se ao fenômeno da

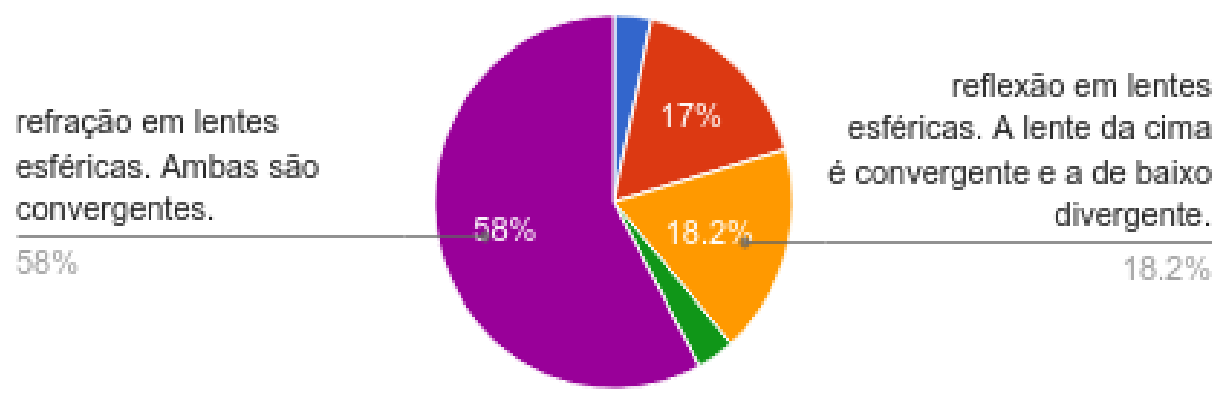

Gráfico 33 - Distribuição das respostas da questão 14 - Pós-teste. 


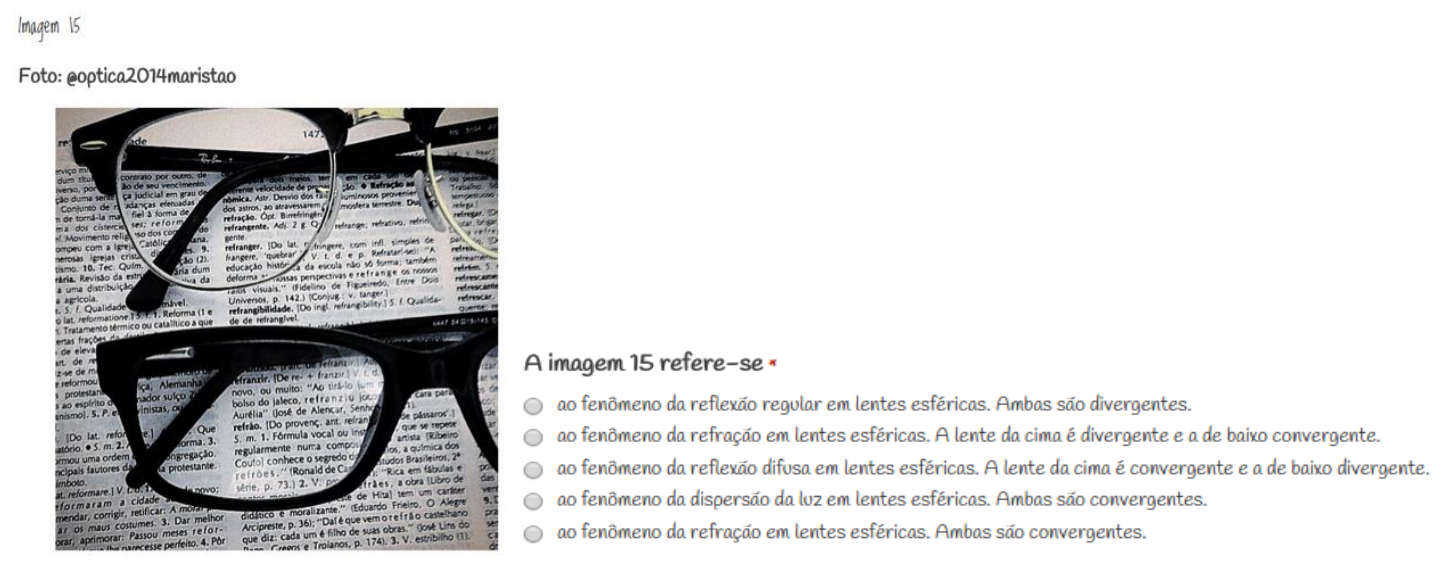

Figura 60 - Captura da tela da questão 15.

A imagem 15 refere-se ao fenômeno da

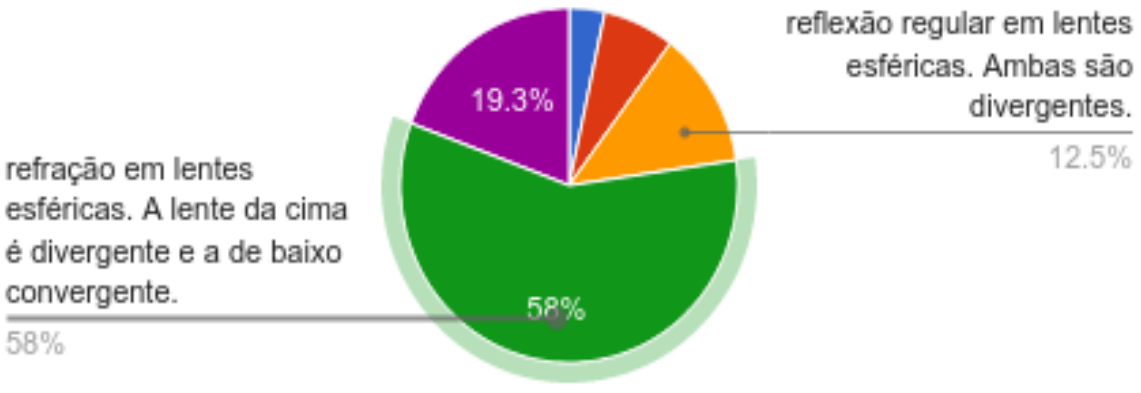

Gráfico 34 - Distribuição das respostas da questão 15 - Pós-teste.

A análise das questões 13, 14 e 15 no pré-teste nos mostrou que, em geral, os estudantes não diferenciavam o fenômeno da reflexão do fenômeno da refração, o que provocou, naquele momento, um percentual de acerto muito abaixo da expectativa - 35,1\%, 28,6\% e 36,4\% respectivamente. Já no pós-teste, os percentuais foram, $52,3 \%, 58 \%$ e $58 \%$, respectivamente, o que nos leva, mais uma vez, a inferir que o método adotado se mostra bastante eficiente e mostra que, por meio desta proposta didática, os estudantes passaram a relacionar os esquemas dos livros com a representação cotidiana do fenômeno.

Após análise dos dados da sondagem em comparação ao pós-teste, podemos perceber que, conforme defendeu Paulo Freire em 1969, utilizar a bagagem cultural e o cotidiano dos estudantes, pode sim, facilitar o processo de ensino e aprendizagem. Os dados provam que os estudantes passam a discernir 
os fenômenos ópticos comuns, sendo agora capazes de identificá-los em seu dia a dia, fazendo uma relação direta do que aprenderam na escola com a experiência cotidiana.

O pós-teste foi aplicado após a discussão em sala sobre cada foto apresentada pelos grupos e todos foram orientados a consultar os livros e a rede mundial de computadores. Os estudantes fizeram as atividades utilizando os computadores disponíveis na escola, seus dispositivos pessoais, tais como tablets e smartphones, tranquilamente durante a aula, mostrando-se sempre curiosos a respeito do tema e inclusive discutindo o que haviam errado na sondagem e como percebiam esta diferença a partir de então. O uso das novas tecnologias se mostrou eficiente nessa experiência, pois permitiu uma relação dialógica entre o professor e os alunos, durante todo o desenvolvimento do projeto.

\begin{tabular}{|l|r|}
\hline \multicolumn{2}{|c|}{ Resultados [Pós-teste] } \\
\hline Pontos possíveis & 30 \\
\hline Pontuação média & 24,31 \\
\hline Número de formulários submetidos & 76 \\
\hline
\end{tabular}

Quadro 15 - Média dos estudantes na atividade de pós-teste

A comparação dos quadros da sondagem com o pós-teste mostra que os métodos de aprendizagem ativa - que já tiveram sua eficácia comparada recentemente às das aulas expositivas, em uma meta-análise realizada em mais de 200 estudos distintos - apontam para uma considerável melhora no processo de aprendizagem e na compreensão conceitual por parte dos estudantes [Freeman et al., 2014]. A média passou de 13,74 para 24,31, o que significa um aumento de $56 \%$ na média da turma. 


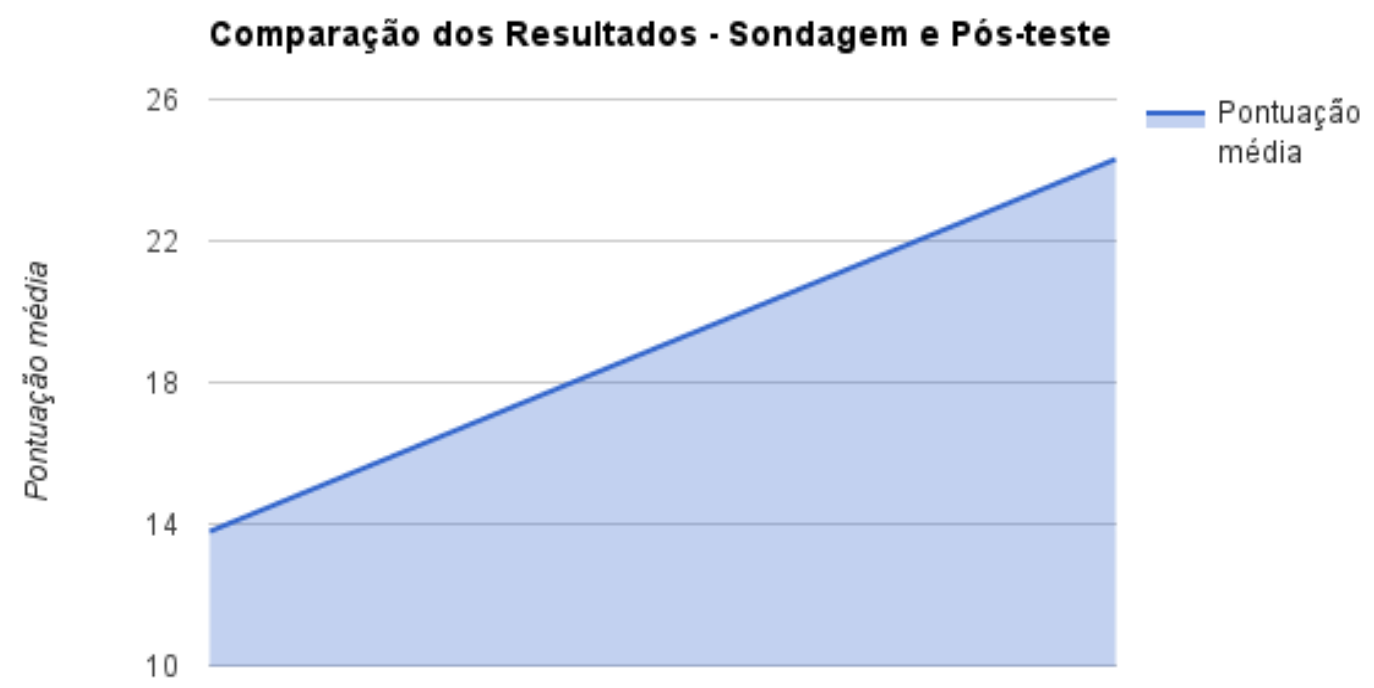
Autora.

Gráfico 1 - Comparação dos resultados da sondagem e do pós-teste. Fonte:

Além da melhora no desempenho acadêmico, notou-se durante o projeto que esta proposta didática é mais eficiente ao suscitar no estudante uma atitude mais adequada diante do estudo, visto que despertou o seu protagonismo acadêmico. Existem no mundo várias experiências nesse sentido voltadas para o ensino de Física [Freeman et al., 2014] e, no Brasil, recentemente, em 2014, o Instituto de Física da USP projetou uma sala para iniciar um projeto com os alunos do bacharelado e da licenciatura em Física sobre o uso de metodologias ativas voltadas para todas as turmas dos cursos iniciais, mostrando a importância desta proposta didática também para o ensino médio [Henriques et al., 2014].

Após a aplicação do pós-teste foi solicitado aos estudantes um Feedback sobre a proposta didática, os dados serão apresentados na próxima sessão.

\subsection{Feedback}

O professor David Hestenes, em artigo publicado em 1987 no American Jornal of Physics, fez uma provocação à comunidade científica a respeito das pesquisas sobre uma teoria de modelagem para o ensino de Física. No artigo, 
Hestenes ressalta que as teorias e pesquisas na pedagogia são geralmente feitas e consideradas de baixa qualidade por cientistas universitários. Mas as práticas didáticas dos professores universitários mostram o quão dolorosamente as pesquisas nessa área são necessárias.

Professores praticam em sala de aula aquilo que eles nunca tolerariam em seus laboratórios. No laboratório, os cientistas estão ansiosos para compreender os fenômenos e avaliar criticamente as hipóteses e alternativas mais razoáveis. Mas as suas aulas são orientadas por crenças infundadas sobre os alunos e sobre os processos de aprendizagem que muitas vezes são erradas ou, na melhor das hipóteses, são meia-verdade. Se esse tipo de comportamento seria desastroso no laboratório, Hestenes pergunta: "Por que este comportamento está presente nas salas de aula? Por que professores não avaliam suas práticas de ensino com os mesmos padrões críticos que se aplicam à investigação científica?"

Enfim, pensando na provocação feita pelo renomado pesquisador e para melhor avaliar esta proposta didática, elaboramos um formulário de Feedback, considerando as percepções levantadas ao longo dos anos de docência em que esta educadora aplica metodologias ativas de ensino durante as aulas. Em verdade, acreditamos que a sala de aula é um laboratório de aprendizagens e cabe aos professores explorar este ambiente da forma a favorecer a construção significativa do conhecimento, tendo em vista sempre, a aprendizagem e o desenvolvimento de habilidades intelectuais para a nova geração de pessoas que partilham de suas aulas.

Sendo assim, para melhor avaliar a eficiência do método utilizado nesta proposta didática, foi aplicado um questionário de feedback com os estudantes, de forma a coletar mais informações acerca da percepção do corpo discente a respeito da metodologia utilizada. Para tanto, os estudantes foram orientados a responder o feedback apenas se desejassem. Até aquele momento, é valido ressaltar, os estudantes não sabiam que a atividade proposta se tratava de objeto de estudo de um mestrado, pois acreditamos que tal informação poderia 
influenciar suas respostas, disposição e avaliação da proposta didática. O formulário não identificava os alunos, dando assim, total liberdade para que opinassem a respeito da proposta. Dito isso, apresentaremos a seguir a percepção dos estudantes a respeito do projeto.

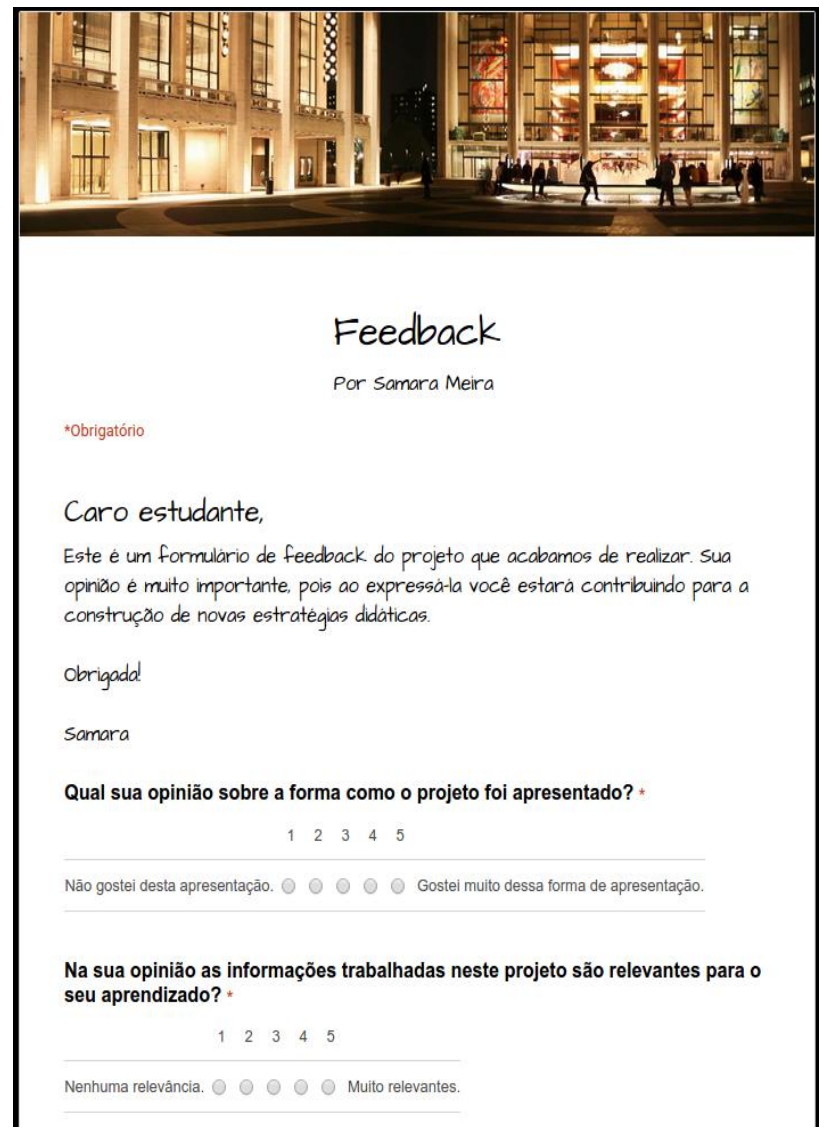

Figura 61 - Captura de tela do Formulário aplicado.

A primeira pergunta abordava o tema do projeto:

Qual sua opinião sobre a forma como o projeto foi apresentado? *

$\begin{array}{lllll}1 & 2 & 3 & 4 & 5\end{array}$

Nāo gostei desta apresentaçāo. $\bigcirc \bigcirc \bigcirc \bigcirc$ Gostei muito dessa forma de apresentaçāo.

Figura 62 - Captura de tela da primeira pergunta do feedback 


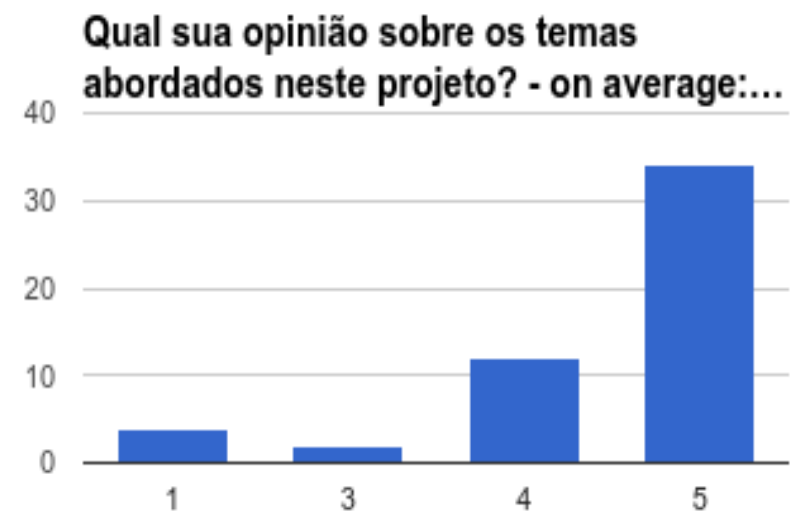

Gráfico 36 - Distribuição das escalas da primeira pergunta do Feedback

A primeira pergunta do feedback, em forma de escala, foi elaborada com intuito de verificar se o estudante percebia alguma diferença na estrutura de apresentação do projeto, no caso desta dissertação, a apresentação via site na internet. Percebemos que a maior parte dos alunos demonstrou gostar dessa forma de apresentação atribuindo nota 5 , máxima na escala. A segunda pergunta estava relacionada aos temas do projeto:

Na sua opinião as informações trabalhadas neste projeto são relevantes para o seu aprendizado? *

$\begin{array}{lllll}1 & 2 & 3 & 4 & 5\end{array}$

Nenhuma relevância. $\bigcirc \bigcirc \bigcirc$ Muito relevantes.

Figura 63 - Captura de tela da segunda pergunta do feedback

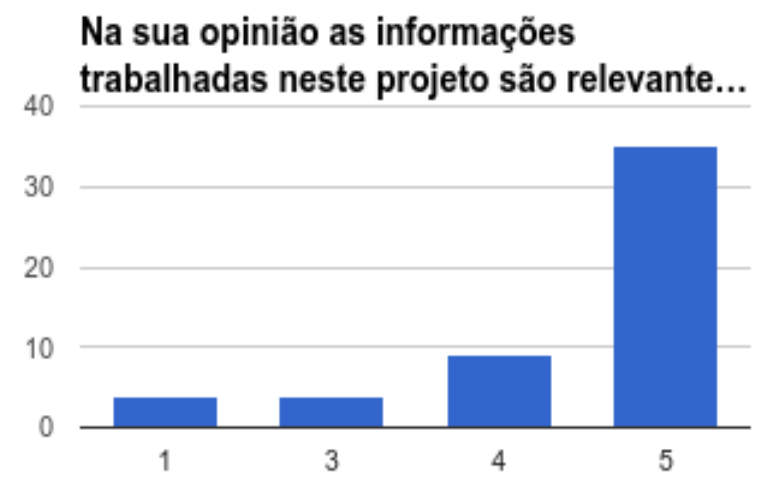

Gráfico 37 - Distribuição das escalas da segunda pergunta do Feedback 
Nesta segunda questão podemos perceber que a maioria dos estudantes considera o tema do projeto muito relevante para o seu aprendizado naquele ano. Demonstrando como os estudantes são capazes de avaliar a importância dos tópicos de física abordados.

A terceira pergunta estava mais associada à metodologia aplicada, queríamos verificar qual a percepção dos estudantes a respeito da aprendizagem por pares (Peer Instruction).

\section{Como você avaliaria as discussões realizadas com o grupo durante 0 planejamento do projeto? *}

$\begin{array}{lllll}1 & 2 & 3 & 4 & 5\end{array}$

As discussōes com o grupo nāo acrescentaram em nada para o meu aprendizado.
As discussōes com o grupo me ajudaram a compreender melhor os fenômenos ópticos abordados.

Figura 64 - Captura de tela da terceira pergunta do feedback.

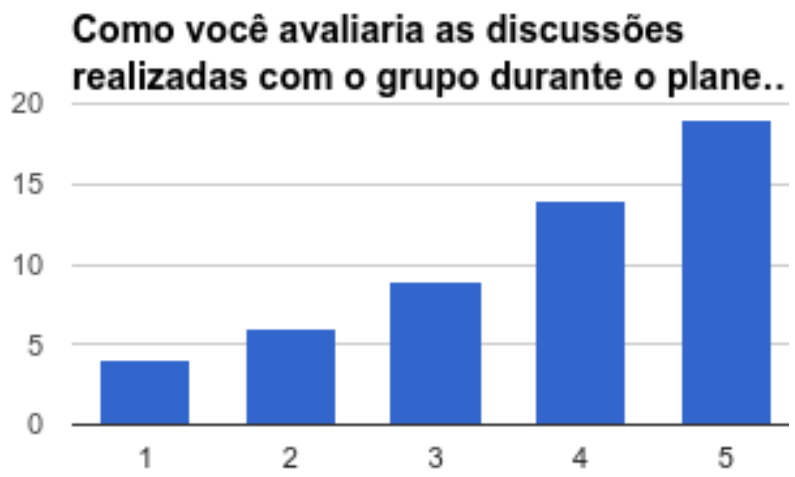

Gráfico 38 - Distribuição das escalas da terceira pergunta do Feedback

Aqui percebemos uma distribuição mais harmônica das respostas, mas em sua maioria os estudantes concordaram que as discussões em grupo o ajudaram na compreensão dos fenômenos abordados. Apenas um estudante relatou não gostar desta forma de abordagem, preferindo uma interferência do professor sobre os tópicos.

$\mathrm{Na}$ quarta pergunta, procurou-se verificar se os estudantes acreditavam mais neste tipo de metodologia ou se preferiam uma aula tradicional, a ideia de se 
recomendar um projeto para o professor, fora apresentada no intuito de mostrar para os colegas docentes como se sentem os estudantes em relação aos métodos centrados nos alunos.

\section{Se um professor estivesse em dúvida sobre realizar um projeto desta natureza em substituição a uma aula expositiva, o que você diria pra ele? *}

$\begin{array}{lllll}1 & 2 & 3 & 4 & 5\end{array}$

Nāo faça este projeto, pois ele nāo substitui uma aula expositiva.
Faça este projeto, pois os estudantes vāo aprender mais do que durante uma aula expositiva.

Figura 65 - Captura de tela da quarta pergunta do feedback.

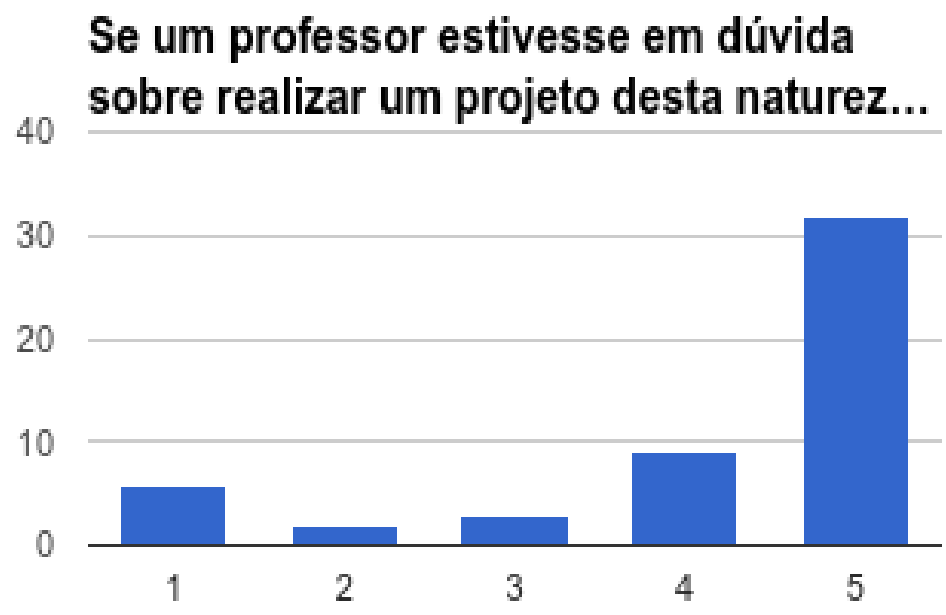

Gráfico 39 - Distribuição das escalas da quarta pergunta do Feedback

A distribuição na escala mostra como os estudantes, que por vezes são tachados de não estarem preocupados com a sua aprendizagem, tem, sim, uma percepção formada a respeito dos métodos que utilizamos e, neste caso, consideram que o projeto permite mais aprendizado do que uma aula expositiva. O resultado vai ao encontro da pesquisa realizada por Albuquerque et al. [2015], publicada no Caderno Brasileiro de Ensino de Física, na proposta que também foi avaliada pelos estudantes, os pesquisadores notaram que é importante diversificar metodologias de ensino para proporcionar oportunidade de aprendizagem para todos. 
Você gostou de fazer este projeto? *

$\begin{array}{lllll}1 & 2 & 3 & 4 & 5\end{array}$

Nāo gostei $\bigcirc \bigcirc \bigcirc \bigcirc$ Gostei muito

Figura 66 - Captura de tela da quinta pergunta do feedback.

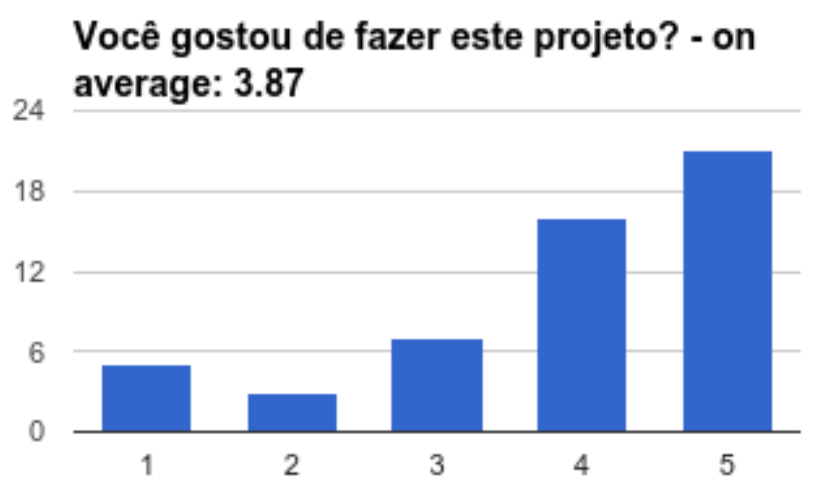

Gráfico 40 - Distribuição das escalas da quinta pergunta do Feedback

De modo geral, como você avalia este projeto? *

\begin{tabular}{lllll}
1 & 2 & 3 & 4 & 5 \\
\hline Muito ruim $\bigcirc$ & $\bigcirc$ & & &
\end{tabular}

Figura 67 - Captura de tela da sexta pergunta do feedback.

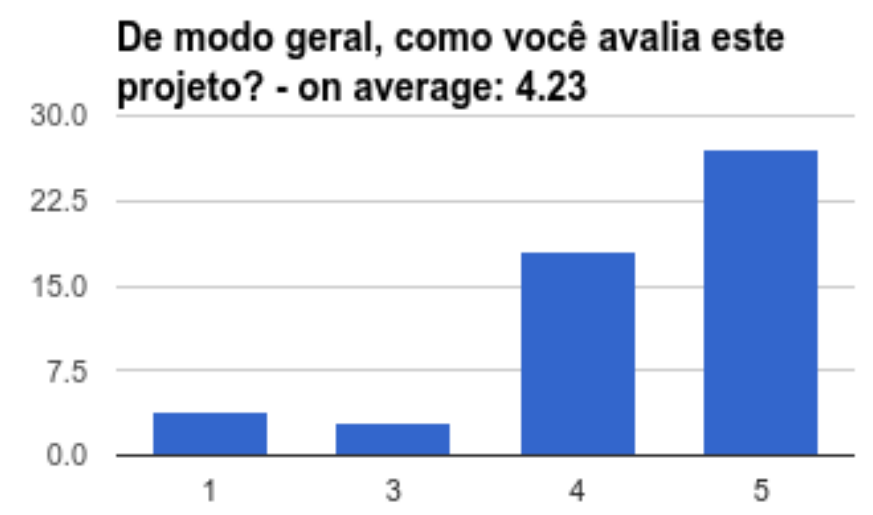

Gráfico 41 - Distribuição das escalas da sexta pergunta do Feedback 
A quinta e a sexta pergunta foram feitas para saber se a proposta didática adotada no projeto agrada aos estudantes. A distribuição na escala mostra que os estudantes gostaram e aprovam a proposta didática.

Por fim, apresentamos uma questão aberta, de forma que os estudantes pudessem expressar sua opinião acerca do projeto.

Este espaço é destinado para você compartilhar mais alguma opinião sobre a sua experiência neste projeto.

Figura 68 - Captura de tela da sexta pergunta do feedback.

Para fazer uma análise dessa questão construímos uma nuvem de palavras, que mostra aquelas que mais se repetiram, vejamos.

AJUDOU SALA CADA SUA AMOR PRECISANDO

PROJETO DELE DEVERIA MAS PONTOS

PELO POUCO POR PUDE ALUNO MEU

OS FOSSE DOS UM TER HASHTAG

samara aula FOI TRABALHO

GOSTEI MELHOR

PROFESSORA SER PARA CAPACIDADE MINHA BOA

CREIO COLEGAS DA IDEIA SERIA PODERIA

integrantes nao bus alguns MUITO apesar

ENTENDER UMA

Figura 69 - Nuvem de palavras 
A nuvem construída com as percepções dos estudantes mostra que as palavras, TRABALHO, MUITO e ENTENDER apareceram de forma recorrente. A seguir alguns depoimentos - positivos e negativos - dos estudantes. Ressaltamos que o número de comentários positivos é muito maior que o número de comentários negativos e que apenas três estudantes se manifestaram negativamente a respeito da proposta didática adotada no projeto. No entanto, consideramos que esta informação é importante e deve ser apresentada nesta dissertação com a mesma ênfase dos comentários positivos.

\section{Comentários Positivos}

Aluna 1: Ter um trabalho desse tipo todos os trimestres, achamos divertido e o aprendizado foi mais eficiente.

Aluno 3: Trabalhoso, mas ajudou a ter conhecimento a respeito de fenômenos ópticos.

\section{Comentários Negativos}

Aluno 2: Muitas vezes, em projetos com postagens, as pessoas perdem pontos em coisas pequenas que não representam sua capacidade de absorver o conteúdo proposto. Por exemplo, cada hashtag valia poucos pontos. No entanto, a capacidade de digitar a hashtag não nos diz se o aluno absorveu a matéria. Logo, o estudante não deveria perder pontos por isso.

Aluno 4: Creio que o trabalho seja de grande aprendizado, porém demanda muito tempo que poderia ser usado em uma aula expositiva. $\mathrm{Na}$ minha opinião o trabalho não substitui uma aula expositiva e o treino de questões.

Aluno 8: Esse trabalho apesar de contribuir em alguns aspectos foi difícil, inclusive para verdadeiramente entender os fenômenos. Apenas alguns integrantes do grupo entenderam e pelo trabalho ser feito com os colegas fica até mais difícil de tirar dúvida e mostrar que não entende, uma vez que o aluno chega a ser um pouco excluído do trabalho e ter ainda mais dificuldade em continuar com a matéria. Talvez se o trabalho envolvesse alguma coisa individual e teórica e que fosse ser visto pelo professor 
Aluno 9: Aprendi muito com a realização deste trabalho. A fotografia possibilitou a mim, além de um êxtase visual, a oportunidade de entender algo que é comumente apresentado em desenhos e linhas; e é complicado imaginar, somente imaginar, como realmente seria o fenômeno descrito em sala de aula. Agora que pesquisei, registrei e experimentei cada fenômeno, tenho não só o auxílio de mídias da web, mas também o meu próprio registro visual, a prova concreta de que experimentei, saboreei e compreendi finalmente os fenômenos ópticos em questão. Espero encontrar mais trabalhos assim. antes da nota fosse uma boa ideia, assim o aluno poderia entender melhor e não ficar se sentindo mal perante o grupo.

Quadro 16 - Comentários positivos e negativos a respeito do projeto.

Quando questionados a respeito da sua experiência pessoal no projeto, percebemos que em sua maioria os estudantes gostaram da nova proposta didática e que para eles houve aprendizagem no relacionamento das situações cotidianas ao conteúdo de física. Apenas um estudante considerou a proposta ineficiente, preferindo aulas tradicionais.

Com relação ao estudante que questionou a pontuação relativa ao uso das hashtag convém ressaltar que apesar de não fazer parte do conteúdo de Física, quando optamos por uma educação libertadora e direcionada para o desenvolvimento de novas habilidades, ao adotar uma hashtag, o usuário assume uma posição dentro de determinado contexto, criando uma identidade que pode ser transportada para o mundo físico [Coelho, 2014]. Nesse caso, introduzindo-o no rol de usuários responsáveis por fazer divulgação científica na rede, a inclusão desta habilidade motivou a pontuação adotada no projeto.

Outros ainda ressaltaram a importância da interação com os colegas para a aprendizagem, mostrando que a relação dialógica proposta por Freire é bem recebida pela comunidade discente. 


\section{CONSIDERAÇÕES FINAIS}

O ethos do eterno aprendiz, esta foi a chama que se manteve acesa ao elaborar esta nova proposta didática. Depois de alguns anos na sala de aula, percebemos o quanto à nossa práxis pode influenciar positiva ou negativamente os estudantes [Mazur, 1990]. Ensinar física é um desafio para as mais belas mentes das ciências, pois o conteúdo é por si só extremamente instigante e atraente sob o ponto de vista dos seus estudiosos. No entanto, devido à herança escolástica do método prussiano de ensino atuamos, diariamente, em sala de aula como se somente a aprendizagem mecânica dos fenômenos bastasse para compreendê-los.

Todo educador ao longo da sua trajetória acadêmica e profissional, deparase com diversos métodos e estratégias de ensino e procura incorporá-las na medida que se ajustam à dinâmica da sua sala de aula. Dessa forma, para o estudo elaborado nesta dissertação foi extremamente difícil escolher apenas um, dois ou três referenciais teóricos, pois ao fazê-lo corre-se o risco de não citar todos os educadores que influenciaram na construção da proposta didática deste projeto.

Acreditamos que os processos de ensino e aprendizagem sejam fluídos e em constante modificação, tendo em vista que a humanidade se reorganiza diante dos novos desafios e, consequentemente, altera o seu processo de cognição. É fácil perceber as diferenças de comportamento dos jovens de cinco em cinco anos, durante as aulas, é incrível como os jovens lidam com a tecnologia de forma mais orgânica que seus pais, da mesma forma é incrível como temos de ajustar nossas estratégias às demandas das novas gerações.

Metodologias de ensino que entendem os sujeitos dos processos de ensino e aprendizagem como professorlocutor e aluno-receptor não propiciam a formação de cidadãos que atendam aos anseios da sociedade atual. [Costa e Pinheiro, 2013] 
Os resultados alcançados nesta pesquisa nos mostram que há, sim, um novo caminho a seguir, entre tantas outras estratégias que se pode adotar para trabalhar o ensino dos fenômenos ópticos. A ideia, aqui, foi oferecer uma alternativa, que se mostrou um pouco mais atraente para a geração. $O$ professor atuando como um designer de conteúdos, gestor de curiosidades, eximindo-se de ser apenas um simples passador conteúdos, termos e nomes diferentes. Pensamos que as ciências, nessa etapa acadêmica, devem ser atraentes aos jovens, afinal de contas o que queremos é aumentar o número de pessoas envolvidas no desenvolvimento das ciências e tecnologias.

Convém ressaltar que o ponto fundamental da proposta didática elaborada não é a tecnologia em si, mas a interação social voltada para a aprendizagem dos conteúdos que se dá ao colocar o aluno no centro do processo educativo, transformando o professor em um agente facilitador dessa aprendizagem. Manter a estrutura tradicional expositiva apenas acrescentando alguma nova tecnologia, pode até trazer um elemento novo de motivação para os estudantes e guiar o professor na sequência de sua exposição oral, mas negligencia o ponto forte das metodologias ativas que é a promoção de um engajamento interativo em sala de aula focado no diálogo [Araújo e Mazur, 2013].

O produto, que é resultado desta pesquisa, é uma forma de se apresentar à comunidade docente como podemos nos reinventar como educadores em busca da aprendizagem dos nossos alunos. Ao adotar estratégias diferenciadas das tradicionais permeadas pelo advento das novas tecnologias, deixamos evidente para os estudantes o nosso interesse em seu processo de construção do conhecimento.

Assim, ensinar ou aprender, na era da informação, exige mudanças nos paradigmas de ensino. O importante é utilizar as tecnologias de forma que nos ajudem a aprender, levando-nos a transformar informação em conhecimento e, mais ainda, em sabedoria, pois a interligação permite aperfeiçoar 0 pensamento reflexivo como 
instrumento de emancipação humana. [Cruz, 2008, p. 1029]

Além do site elaborado para o projeto, não podemos deixar de citar o banco de imagens a respeito dos fenômenos ópticos construído ao longo dos três anos em que o trabalho foi aplicado. São cerca de 2000 imagens que podem ser utilizadas por professores e estudantes do mundo inteiro para compreender os fenômenos ópticos. Dessa forma, percebemos que o alcance deste projeto não está restrito aos estudantes que fizeram e participaram do trabalho, mas contribui em escala mundial para divulgação científica e proporciona mais um espaço para aprendizagem em rede [Siemens, 2010].

Difundir uma cultura entre os jovens de desmistificação da Física como matéria desconexa do nosso dia a dia é uma tarefa que pode ser realizada pelos próprios jovens, como vimos neste projeto, quando eles concordaram em divulgar os temas pesquisados em suas redes sociais. Tal desmistificação e potencialidade de replicabilidade das experiências apontam para as vantagens desta nova proposta didática em contrapartida aos métodos tradicionais que visam transmitir algo pronto, verdades absolutas que estão fora do mundo dos estudantes.

Ensinar, segundo a concepção propedêutica, é transmitir algo pronto, uma verdade absoluta que está fora do aprendiz. Primeiro o professor transmite e 0 aluno assimila, para depois [no ano seguinte, no Ensino Médio, no vestibular, na vida adulta] ser utilizado. Primeiro vem a teoria, depois a prática [a vivência, a vida vivida]. A vivência, normalmente jogada para um horizonte que ultrapassa o espaçotempo de escola. Com isto, há uma desvinculação entre a sala de aula e a realidade social, entre o "mundo da escola" e o "mundo da vida. [AULER, 2007]

Com o estudo desenvolvido e apresentado nesta dissertação acreditamos que ao invés de depender somente de palestras, aulas tradicionais e livros-texto, um desenho de estratégias de aprendizagem que adote metodologias centradas nos alunos e que se torne um modelo de ensino para professores, pode torná-los especialistas da escola não só sobre o uso das tecnologias no ensino de ciências 
[Hestenes et al., 2008], mas também tem potencial para incentivar a formação horizontal de professor para professor em métodos de ensino da ciência, proporcionando às escolas e demais segmentos da sociedade um recurso valioso para uma reforma mais ampla na educação.

Convém ressaltar que existem estudos mostrando fragilidades a respeito do uso das metodologias ativas no ensino principalmente sob a óptica dos estudantes que, não raras vezes, afirmam se sentirem perdidos em função da abrupta mudança do método tradicional para os métodos ativos, tendo em vista que esses métodos requerem protagonismo e habilidades que ainda não foram desenvolvidas [Marin et al, 2010].

No entanto, acreditamos que estas fragilidades se mostram como mais um grande desafio à docência e à pesquisa no ensino de física, sejam elas de ordem prática ou filosófica, afinal de contas, como bem observa Sagan [1990, Cosmos, Heaven and Hell, Episódio 4], "Há muitas hipóteses em ciência que estão erradas. Isso é perfeitamente aceitável; é a abertura para descobrir o que é certo. A ciência é um processo de auto-correção. Para serem aceitas, novas ideias devem sobreviver aos mais rigorosos padrões de provas e investigação." Esperamos que com este trabalho novos estudos sejam delineados, processos sejam revisados e novas descobertas sejam feitas de forma a auxiliar professores, os verdadeiros cientistas da sala de aula, a promover um ensino de qualidade e que provoque verdadeiras revoluções no desenvolvimento da cidadania das futuras gerações. 


\section{REFERÊNCIAS BIBLIOGRÁFICAS}

[Abegg e Bastos 2012] Abegg, I., \& de Bastos, F. D. P. (2012). Ensino de Física Colaborativo Mediado pelo Wiki do Moodle: descrição e análises dos casos de estudos. Caderno Brasileiro de Ensino de Física, 29(0), 2012, p. 729-757. Disponível em: <http://doi.org/10.5007/2175-7941.2012v29nesp2p729.>. Acesso em: 12 dez. 2015.

[Albuquerque et. al 2015] Albuquerque, K. B. et. al. Os Três Momentos Pedagógicos como metodologia para o ensino de Óptica no Ensino Médio: o que é necessário para enxergarmos? Caderno Brasileiro de Ensino de Física, 2015. Disponível em: <https://periodicos.ufsc.br/index.php/fisica/article/view/21757941.2015v32n2p461>. Acesso em: 12 dez. 2015.

[Araújo e Mazur 2013] Araújo, I. S., \& Mazur, E. Instrução pelos colegas e ensino sob medida: uma proposta para o engajamento dos alunos no processo de ensinoaprendizagem de Física. Caderno Brasileiro de Ensino de Física, abr. 2013. Disponível em: <https://periodicos.ufsc.br/index.php/fisica/article/view/21757941.2013v30n2p362>. Acesso em: 5 Mai. 2016.

[Auler 2013] Auler, D. Articulação Entre Pressupostos do Educador Paulo Freire e do Movimento CTS: Novos Caminhos Para a Educação em Ciências. Revista Contexto \& Educação, mai. 2013. Disponível em: $<$ https://revistas.unijui.edu.br/index.php/contextoeducacao/article/view/1089>. Acesso em: 13 Dez. 2015.

[Binsfeld et. al 2009] Binsfeld, S. C.; Auth, M. A. A Presença Da Divulgação Científica No Processo De Ensino-Aprendizagem Do Nível Médio. VII Encontro Nacional de Pesquisa Em Educação Em Ciências, 2009. Florianópolis. Disponível em: <http://posgrad.fae.ufmg.br/posgrad/viienpec/pdfs/1531.pdf>. Acesso em: 13 dez. 2015. 
[Chai et. al 2013] Chai, C. S.; Koh, J. H. L.; Tsai, C.-C. (2013). A Review of Technological Pedagogical Content Knowledge. Educational Technology \& Society, 16, 2013, p. 31-51. Disponível em: http://doi.org/10.1111/j.13652729.2010.00372.x. Acesso em: 6 jun. 2016.

[Coelho 2015] Coelho, P. Através dos filtros: a diversificação da identidade através do uso do Instagram, 2015. Disponível em: <http://casperlibero.edu.br/wpcontent/uploads/2015/01/Pietro-Coelho-ESPM.pdf>. Acesso em: 13 dez. 2015.

[Connolly 2016] CONNOLLY, I.; et. al. An Introduction to Cyberpsychology. 1.ed. New York: Routledge, 2016. Disponível em: https://books.google.com.br/books?id=R6TDCwAAQBAJ\&lpg=PA194\&ots=mnOTl-nG7\&dq=SMAR model edtech\&lr\&hl=pt-BR\&pg=PA89\#v=0nepage\&q\&f=false . Acesso em 2 jun. 2016.

[Costa et. al 2013] Costa, J. De M.; Pinheiro, N. A. M. O ensino por meio de temas-geradores: a educação pensada de forma contextualizada, problematizada e interdisciplinar. Imagens Da Educação, 3(2), 2013, p. 37-44. Disponível em: <http://doi.org/10.4025/imagenseduc.v3i2.20265>. Acesso em: 6 jun. 2016.

[Cruz 2008] Cruz, J. M. Processo de Ensino-Aprendizagem na Sociedade da Informação, 2008.2 Disponível em: <http://www.scielo.br/pdf/es/v29n105/v29n105a05>. Acesso em 6 jun. 2016.

[Deleuze e Guattari 1995] Deleuze, G.; Guattari, F. Mil Platôs. São Paulo: Editora 34, 1995. Disponível em: <http://escolanomade.org/wpcontent/downloads/deleuze-guattari-mil-platos-vol1.pdf>. Acesso em: 5 jun. 2016.

[Demo 2005] Demo, P. A Educação Do Futuro E O Futuro Da Educação. Campinas,SP, $2005 . \quad$ Disponível em:< https://books.google.com.br/books/about/A Educacao Do Futuro E O Futuro D a Educa.html?hl=pt-br\&id=n2LImjGA4e8C>. Acesso em: 5 jun. 2015. 
[Equipe InfoMoney 2010] Equipe Infomoney. Quem são, como vivem e o que pensam os jovens da Geração Z?, 2010. Disponível em: <http://www.sebraesc.com.br/newart/default.asp?materia=18767 >. Acesso em: 5 jun. 2016.

[Feixa e Leccardi 2010] Feixa, C., \& Leccardi, C. O conceito de geração nas teorias sobre juventude. Sociedade e Estado, 25(2), 2010, p. 185-204. Disponível em: <http://doi.org/10.1590/S0102-69922010000200003>. Acesso em: 5 jun. 2015.

[Fernandes et. al 2015] Fernandes, G.; Rodrigues, A.; Ferreira, C. Módulos temáticos virtuais: uma proposta pedagógica para o ensino de ciências e o uso das TICs. Caderno Brasileiro de Ensino de Física, out. 2015. Disponível em: $<$ https://periodicos.ufsc.br/index.php/fisica/article/view/2175-

7941.2015v32n3p934>. Acesso em: 8 jun. 2016.

[Ferracioli e Sampaio 2001] Ferracioli, L.; Sampaio, F. F. Informação, Ciência, Tecnologia e Inovação Curricular em Cursos de Licenciatura. Revista Brasileira de Informática Na Educação, 8(1), 2001, p. 83-88.

[Feynman 1963] Feynman, R. (1963). The Feynman Lectures on Physics: Feynman's Preface, 1963. Disponível em: <http://www.feynmanlectures.caltech.edu/l 91.html>. Acesso em: 8 jun. 2015.

[Fraga 2012] Fraga, L. M. D. As novas tecnologias de comunicação e informação: o uso das mídias sociais como ferramenta no processo de ensino e aprendizagem, out. 2012. Disponível em: <http://bdm.unb.br/handle/10483/5131>. Acesso em: 8 jun. 2015.

[Franco 2009] Franco, A. de. TEDxSP, 2009. Disponível em: $<$ https://www.youtube.com/watch?v=-3bnzmykCiM>. Acesso em: 2 jun. 2016.

[Freeman et. al 2014] Freeman, S.; et al. Active learning increases student performance in science, engineering, and mathematics. Proceedings of the 
National Academy of Sciences of the United States of America, 111(23), 2015, p.8410-5. <http://doi.org/10.1073/pnas.1319030111> Acesso em Junho 2016

[Freire 1974] Freire, P. Pedagogia do Oprimido, Rio de Janeiro, Paz e Terra, 1974.

[Gabriel 2016] GABRIEL, Martha. Relação da Aprendizagem ativa com a tecnologia, 2016. Disponível em: www.positivoteceduc.com.br/em-pauta/marthagabriel-aborda-aprendizagem-ativa-e-tecnologial. Acesso em: 5 jun. 2016.

[Garcia 2015] Garcia, L. M. M. Facebook/Google como ferramentas de suporte ao ensino colaborativo/cooperativo: proposta de um modelo. Universidade Portucalense, 2015.2 Disponível em: <http://repositorio.uportu.pt//handle/11328/1300>. Acesso em: 2 jun. 2016.

[Giglio e Souza 2013] Giglio, K.; Souza, M. Mídias, redes sociais e ambientes virtuais: pensando a educação em rede, 2013. Disponível em: $<$ http://www.aedi.ufpa.br/esud/trabalhos/oral/AT4/114169.pdf>. Acesso em 2 jun. 2015.

[Halloun e Hestenes 1985] Halloun, I. A.; Hestenes, D. The initial knowledge state of college physics students. American Journal of Physics, 53(11), 1985, p.10431048. Disponível em: <http://doi.org/10.1119/1.14030>. Acesso em: 2 jun. 2016.

[Henriques et. al 2014] Henriques, V. B.; Prado, C. P. C.; Vieira, A. P. Editorial convidado: aprendizagem ativa. Revista Brasileira de Ensino de Física, 36(4), 2014, p. 01-02. Disponível em: <http://doi.org/10.1590/S1806$11172014000400001>$. Acesso em 8 jun. 2016.

[Hestenes 1987] Hestenes, D. Toward a modeling theory of physics instruction. American Journal of Physics, 55(5), 1987, p. 440-454. Disponível em: <http://doi.org/10.1119/1.15129>. Acesso em: 5 jun. 2016. 
[IBGE 2014] INSTITUTO BRASILEIRO DE GEOGRAFIA E ESTATISTICA. Uso da Internet no Brasil, 2014. Disponível em: $<$ http://www.ibge.gov.br/home/estatistica/populacao/acessoainternet/comentarios.p df>. Acesso em: 2 jun. 2016.

[Inhauser et. al 2010] Inhauser, N.; et al. A prática docente frente à desatenção dos alunos no ensino fundamental. Teaching practice dealing with students' lack of attention in the primary school. Rev. CEFAC 12(5), Set-Out, 2010, p. 756-765.

[Jackson et. al 2005] Jackson, J.; Dukerich, L.; Hestenes, D. Modeling Instruction : An Effective Model for Science Education. Science Educator, 17(1), 2005, p.1017. Disponível em: <http://doi.org/10.1007/s10972-010-9225-9>. Acesso em: 5 jun. 2016.

[Juliani et. al 2013] Juliani, D. P.; Souza, J. A. de; Bettio, R. W. de. Utilização das redes sociais na educação: guia para o uso do Facebook em uma instituição de ensino superior. RENOTE, 2013. Disponível em: $<$ http://www.seer.ufrgs.br/index.php/renote/article/view/36434>. Acesso em: 5 jun. 2016.

[Karwatzki e Blauth 2015] Karwatzki, W.; Blauth, L. Fotografia para inclusão de jovens com necessidades especiais, 2015. Disponível em $<$ http://www.fundepe.com/jee2016/cd/arquivos/107919.pdf> Acesso em Junho 2016

[Koehler 2015] Koehler, M. TPACK, 2015. Acesso Junho, 2016. Disponível em: $<$ http://www.tpack.org/>. Acesso em: 14 jun. 2015.

[Lacerda e Silva 2014] Lacerda, A. L. de.; Silva, T. da. Possibilidades pedagógicas na perspectiva de uma educação online. Caderno Brasileiro de Ensino de Física, set. 2014. Disponível em: 
$<$ https://periodicos.ufsc.br/index.php/fisica/article/view/2175-

7941.2015v32n1p157>. Acesso em: 2 jun. 2016.

[Lemos 2005] Lemos, A. Cibercultura e Mobilidade. A Era da Conexão, 2015. Disponível em: <http://www.intercom.org.br/papers/nacionais/2005/resumos/r14651.pdf > Acesso em: 4 jun. 2016.

[Lévy 1997] Lévy, P. Cibercultura, 1997. Disponível em: $<$ http://www4.pucsp.br/pos/tidd/teccogs/resenhas/2010/edicao 3/3-ciberculturapierre levy.pdf>. Acesso em: 8 jun. 2015.

[Marin et. al 2010] Marin, M. J.; et al. Aspectos das fortalezas e fragilidades no uso das Metodologias Ativas de Aprendizagem. Revista Brasileira De Educação Médica, 34, 2010. P.13-20. Disponível em: <http://www.scielo.br/pdf/rbem/v34n1/a03v34n1 >. Acesso em: 4 jun. 2016.

[Martinho e Pombo 2009] Martinho, T.; Pombo, L. Potencialidades das TIC no ensino das Ciências Naturais - um estudo de caso. Revista Electrónica de Enseñanza de Las Ciencias, 8(2), 2009, p. 527-238. Disponível em: <http://reec.uvigo.es/volumenes/volumen8/ART8 Vol8 N2.pdf >. Acesso em: 4 jun. 2016.

[Mazur 1997] Mazur, E. (1997). Peer Instruction: A User's Manual. Upper Saddle River, NJ: Prentice Hall, 1997. Disponível em:

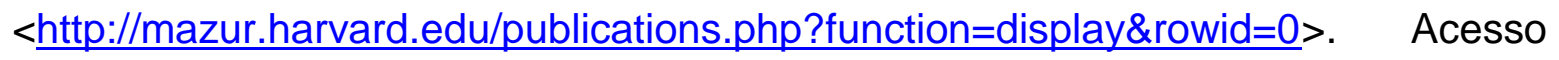
em: 4 jun. 2016.

[Melo 2014] Melo, R. G. de. Uso de redes sociais por estudantes do ensino médio de uma escola privada de Natal: análise do comportamento informacional. Biblioteconomia, $2014 . \quad$ Disponível em: <http://monografias.ufrn.br:8080/jspui/handle/123456789/921>. Acesso em: 4 jun. 2016. 
[Mishra et. al 2006] Mishra, P.; Koehler, M. J.; Bragg, W. H. Technological Pedagogical Content Knowledge: A Framework for Teacher Knowledge. Teachers College Record, 108(6), 2006, p.1017-1054.

[Moran 1997] Moran, J. Como Utilizar a Internet na Educação. Revista Ciência Da Informação, 26(2), 1997, p. 146-153.

. Novos desafios na educação - a Internet na educação presencial e virtual, 2008, p.1-15.

Relatos de experiências. Disponível em: $<$ http://www.scielo.br/pdf/ci/v26n2/v26n2-5.pdf>. Acesso em: 2 jun. 2016.

[Muller 2013] Muller, M. G. Metodologias interativas de ensino na formação de professores de Física: Um estudo de caso com o Peer Instruction, 2013. Disponível em: $<$ https://www.lume.ufrgs.br/bitstream/handle/10183/72092/000882183.pdf?sequen $\underline{\mathrm{ce}=1}$ >. Acesso em: 6 ago. 2015.

[Neto 1983] Neto, D. Ensino de física e a concepção freireana da educação. Revista Brasileira de Ensino de Física, 85, 1983. Disponível em:

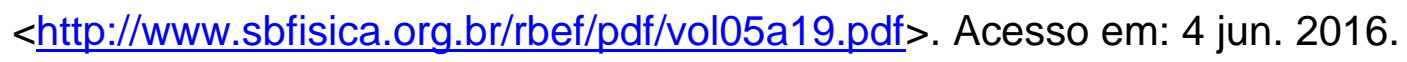

Parâmetros Curriculares Nacionais do Ensino Médio, 2000. Disponível em: < http://portal.mec.gov.br/seb/arquivos/pdf/blegais.pdf>. Acesso em: 3 jun. 2016.

Pesquisa Brasileira De Mídia. Entre selfies e curtidas, 2015. Disponível em: $<$ https://focagen.wordpress.com/2015/07/06/entre-selfies-e-curtidas-aautoexposicao-na-internet/>. Acesso em: 3 jun. 2016.

Pontifícia Universidade Católica do Paraná. Do quadro negro ao Tablet, Disponível em: <http://www.lami.pucpr.br/newsletter/site news/artigo0103b.php>. Acesso em: 4 jun. 2016. 
[Puentedura 2003] Puentedura, R. R. SAMR: A Contextualized Introduction, 2003. Disponível

em:

<http://www.hippasus.com/rrpweblog/archives/2013/10/25/SAMRAContextualizedl ntroduction.pdf>. Acesso em: 3 jun. 2016.

[Resende 1999] Resende, C. A. Didática em perspectiva. São Paulo: Tropical, 1999.

[Salomon 2013] Salomon, D. Estamos usando menos o facebook e twitter e mais Instagram, 2013.2 Disponível em: $<$ www.techtudo.com.br/noticias/noticia/2014/05/estamos-usando-menos-facebooke-twitter-e-mais-instagram-e-tumblr-diz-estudo.html> Acesso em: 3 jun. 2016.

[Santos e Santos 2015] Santos, V. L. da C.; Santos, J. E. dos. As redes sociais digitais e sua influência na sociedade e educação contemporâneas. Holos, fev. $2015 . \quad$ Disponível em: <http://www2.ifrn.edu.br/ojs/index.php/HOLOS/article/view/1936 >. Acesso em: 2 jun. 2016.

[Shulman 1986] Shulman, L. S. Those who understand: Knowledge growth in teaching, 15(2), 1986, p. 4-14. Disponível em: $<$ http://www.jstor.org/stable/1175860>. Acesso em: 3 jun. 2016.

[Siemens 2010] Siemens, G. TEDxNYED, 2010. Disponível em: $<$ http://tedxtalks.ted.com/video/TEDxNYED-George-Siemens-030610>. Acesso em: 2 jun. 2016.

Connectivism: A Learning Theory for the Digital Age, 2004. Disponível em: <http://www.elearnspace.org/Articles/connectivism.htm>. Acesso em: 4 jun. 2016.

[Silva 2001] Silva, M. Sala de aula interativa a educação presencial e à distância em sintonia com a era digital e com a cidadania, 2001, p. 1-20. 
[Fleury e Fleury 2001] Fleury, L.; et al., 2001 Construindo o Conceito de Competência, Resumo, R. R., \& Resumo, p. 183-196.

[Veraszto, et. al 2009] Veraszto, E. V.; et al.. Tecnologia : buscando uma definição para o conceito Technology: looping for a definition for the concept Resumo Abstract, Prisma.com, Campinas, 2009, p. 19-46.

[Wang e Tchernev 2012] Wang, Z., \& Tchernev, J. M. The "Myth" of Media Multitasking: Reciprocal Dynamics of Media Multitasking, Personal Needs, and Gratifications. 2012. Journal of Communication, 62[3], 493-513. http://doi.org/10.1111/j.1460-2466.2012.01641.

[Pino] Interatividade, Disponível em <http://www.lite.fe.unicamp.br/sapiens/interatividade.htm> Acesso em Junho 2015

[Oliveira 2016] OLIVEIRA, M. M. Breve história dos processos de reprodução. Revista de Tecnologia Gráfica, 2016. Disponível em: $<$ http://www.revistatecnologiagrafica.com.br/index.php?option=com content\&view= article\&id=5842: breve-historia-dos-processos-de-reproducao\&catid=68:materiasespeciais\&ltemid $=188$ >. Acesso em: 3 jun. 2016. 